\title{
Taxonomic revision of Arisaema (Araceae) sect. Sinarisaema in India
}

\author{
K.M. Manudev ${ }^{1}$, P.G. Arunkumar ${ }^{2}$ \& Santhosh Nampy ${ }^{2}$ \\ ${ }^{1}$ Postgraduate \& Research Department of Botany, St. Joseph's College (Autonomous), Devagiri, \\ Kozhikode District, Kerala - 673 008, India. E-mail: manudevkmadhavan@gmail.com \\ ${ }^{2}$ Department of Botany, University of Calicut, Malappuram P.O., Kerala - 673 635, India. E-mail: santhoshnampy5@gmail.com
}

\begin{abstract}
History and status of the section Sinarisaema Nakai in India are discussed. The present study is a result of intensive field trips across the country from 2010 to 2019. Twenty three species are recognized from the country based on the morphological data procured from live samples as well as herbarium specimens deposited in various herbaria in India and abroad. Two species, viz. A. fischeri Manudev \& Nampy and A. subulatum Manudev \& Nampy are newly described while lectotypes are designated for four names currently treated as synonyms. Detailed description and photographic images are provided for each taxon. A taxonomic key is given for the easy identification in the field. The conservation status of five species is assessed based on the criteria laid out by IUCN.
\end{abstract}

Keywords: Arisaema, Endemism, North-East India, Sect. Sinarisaema, Western Ghats.

\section{Introduction}

Arisaema Mart., commonly called Cobra lilies, is one of the largest genera of the family Araceae. Of the 220 taxa worldwide, 208 are reported from Asia, mainly distributed in India, China and Japan (Govaerts et al., 2019). With fifty species and six varieties, Arisaema becomes the largest genus of Aroid family in India, primarily distributed in the forest outskirts of Western Ghats and temperate Himalayan Mountains. Several authors classified the genus Arisaema: Schott (1860), Engler (1920), Hara (1971), Murata (1984), Gusman and Gusman (2002, 2006), Murata (2011) and Murata et al. (2013). According to Murata et al. (2013), the genus is divided in to 13 sections viz. Sect. Arisaema, Sect. Attenuata (Engl.) H.Li, Sect. Clavata (Engl.) H. Ohashi \& J.Murata, Sect. Decipientia (Engl.) H.Li, Sect. Dochafa (Schott) H.Hara, Sect. Flagellarisaema (Nakai) H.Hara, Sect. Franchetiana (Engl.) H.Hara, Sect. Nepenthoidea (Engl.) Gusman \& L.Gusman, Sect.

Received: 08.05.2019; Revised \& Accepted: 24.06.2019 Published Online: 30.06.2019
Odorata J.Murata ex J.Murata, Sect. Pistillata (Engl.) Nakai, Sect. Sinarisaema Nakai, Sect. Tenuipistillata (Engl.) H.Hara and Sect. Tortuosa (Engl.) Nakai. Nine sections are found to occur in India among which Sect. Sinarisaema Nakai is the largest with 23 taxa.

Section Sinarisaema was originally established by Nakai (1950) to accommodate species with radiate leaves, caudate limb and clavate spadix appendix. Hara (1971) included 10 species, most of them from India and opined that $A$. murray $i$ be included in this section. In addition, he also recognized a monotypic section Exappendiculata to accommodate A. exappendiculatum H.Hara, characterised by the absence of a spadix appendix and annular anthers. Murata (1984) and Gusman and Gusman (2006) treated Sect. Exappendiculata as a subsection under Sinarisaema. Li et al. (2010) abandoned the sectional and subsectional status of Exappendiculata and merged it under Sect. Sinarisaema. The same is followed in the latest circumscription of this section by Murata et al. (2013).

Section Sinarisaema is characterised by radiate leaves with prominent pseudostems, caudate to acuminate spathe limb and clavate spadix appendix, just projecting from the mouth. Sometimes, as in a few south Indian taxa, the spadix appendix is rugose or knobbed at the apex. This section currently includes 38 species and two infraspecific taxa in the world. The section diversified in India and forms the largest section with 23 taxa including the two new species described here. Of the 23 taxa, 18 are endemic and 15 are confined to the Western Ghats.

Arisaema sect. Sinarisaema Nakai, J. Jap. Bot. 25: 6. 1950; Hara, Fl. E. Himal. 347. 1971; Gusman \& L.Gusman, Gen. Arisaema, ed. 2. 349. 2006; Li et al. in Zhu et al., Fl. China, 23: 65. 2010; Murata et al., J. Jap. Bot. 88: 44. 2013. Type: Arisaema formosanum (Hayata) Hayata. 
Arisaema sect. Radiatisecta Schott, Prodr. Syst. Aroid. 26 \& 42. 1860, nom. nud.

Arisaema [unranked] Radiatisecta Engl. in A.DC. \& C.DC., Monogr. Phan. 2: 550. 1879. Type: Not designated.

Arisaema [sect. Radiatisecta] [unranked] ( ${ }^{*} S \mathcal{S}$ a.) Indica Schott, Prodr. Syst. Aroid. 26 \& 44. 1860. Type: Not designated.

Arisaema sect. Peltatisecta Schott, Prodr. Syst. Aroid. $27 \& 48.1860$, nom. nud.

Arisaema sect. Exappendiculata H.Hara, Univ. Mus. Univ. Tokyo Bull. 2: 353. 1971.

Arisaema subsect. Exappendiculata (H.Hara) J.Murata, J. Fac. Sci. Univ. Tokyo. Sect. III 13: 475. 1984.

Arisaema subsect. Exappendiculata (H.Hara) Gusman, Gen. Arisaema, ed. 2. 351. 2006, nom. superfl. Type: A. exappendiculatum H.Hara.

Dioecious, deciduous, perennial herbs. Subterranean stem a tuberous corm, white, cream, green to purplish inside, sometimes stoloniferous. Psuedostem prominent, almost the half the length of petiole. Leaves usually single, rarely 2 ; leaflets $5-25$, radiate, sessile, sometimes petiolulate. Spadix appendix subsessile, very rarely stipitate, clavate or cylindrical, with smooth or rugose or sometimes with a knobbed apex; fruiting peduncle usually erect, sometimes nodding.

\section{Key to the species of section Sinarisaema}

1. Spathe limb cucullate or galeiform .2

1. Spathe limb not cucullate or galeiform .6

2. Tube of spathe 3-angled; limb apex gradually tapering and curved to a parrot like beak A. psittaccus

2. Tube of spathe cylindric; limb apex not curved to a parrot-like beak .3

3. Spadix appendix stipitate; spathe limb ending in a terminal, ovate or obovate, hanging lobe.... 4

3. Spadix appendix not stipitate; spathe limb not ending in a terminal hanging lobe .5

4. Mouth of tube widely auriculate; limb obovate; spadix appendix purplish to green, truncate at apex A. nilamburense

4. Mouth of tube not auriculate; limb ovate; spadix appendix whitish, attenuate at apex A. sarracenioides

5. Male flowers with fused, annulate anthers, spathe limb ending in a long caudate tail

A. agasthyanum

5. Male flowers with free anthers; spathe limb does not ending in a long caudate tail...A. translucens

6. Fruiting peduncles nodding at maturity; leaflets linear to oblong or oblong-elliptic, apex prolonged in to a slender tail. . .7

6. Fruiting peduncles erect at maturity; leaflets ovate-elliptic, elliptic, elliptic-laneolate, lanceolate, oblong or oblanceolate, apex not ending in a tail.

7. Leaflets 7-12, not ending in a drooping tail; spathe limb purplish-brown to carmine, with conspicuous white to pale green stripes along the veins ending in an anastomosis; corms stoloniferous A. ciliatum

7. Leaflets > 15, ending in a drooping tail; spathe limb greenish, devoid of stripes, corms proliferous A. consanguineum

8. Corms purplish inside A. concinnum

8. Corms white, cream, yellow to green inside. 9

9. Spathe limb invariably greenish, not striped......10

9. Spathelimbgreen, yellowishorpurplish, variously striped. .11

10. Leaflets caudate at apex, pale green below; spathe limb caudate at apex, spadix appendix rugose at apex; corms producing bulblets A. caudatum

10. Leaflets acuminate at apex, glaucous beneath; spathe limb acuminate at apex; spadix appendix smooth at apex; corms stoloniferous

A. fraternum

11. Spadix appendix cylindric, terete or clubshaped, stipitate or nearly so 12

11.Spadix appendix slender, filiform or nearly so, sessile.

12. Spathe limb acute-acuminate, not tapering to a long tail (rarely with a tail); spadix appendix stipitate or nearly so 13 
12. Spathe limb narrowly acuminate, tapering in to a tail; spadix appendix sessile .17

13. Mouth margins auriculate, sometimes recurved; spathe limb arching forward or drooping; spadix appendix cylindric, truncate or round at apex, very rarely pointed. . .14

13. Mouth margins not auriculate, not recurved; spathe limb usually erect; spadix appendix fusiform, ending in a warted knob at apex..... A. barnesii

14.Spadix appendix echinate at apex. 15

14.Spadix appendix smooth, rarely rugulose .....16

15.Spathe dull-white, densely streaked with irregular purple blotches..........A. arunachalense

15.Spathe green or purple with white parallel stripes. A. echinatum

16.Male spadix with subulate neuters

A. peerumedense

16.Male spadix without subulate neuters A. leschenaultii

17. Mouth margins auriculate, sometimes recurved A. subulatum

17.Mouth margins not auriculate, not recurved..... .18

18. Spadix appendix with a knobbed apex .... A. fischeri

18. Spadix appendix not ending in a knobbed apex.... 19

19.Spathe tube narrowing in the upper third, then flaring again at mouth; spathe limb dull orange-yellow with pale pink stripes, drooping downward ... A. siangense

19.Spathe tube cylindric or funnel-shaped; spathe limb bright green to yellowish green or brownish, white striped, erect when young then drooping..... A. peltatum

20.Margins of the mouth widely auriculate; limb base narrower than the mouth, margins curved back forming a neck like constriction....................................A. madhuanum

20.Margins of the mouth not widely auriculate; limb base as wide as the mouth, margins not curved back 21

21.Plants c. $30 \mathrm{~cm}$ tall; spathe limb ovate, green without a white patch at the base; spadix appendix terminating in a distinct, minutely warted knob.. A. tylophorum

21.Plants above $40 \mathrm{~cm}$ tall; spathe limb triangular or elongate-lanceolate, green with a large white patch at the base; spadix appendix gradually tapering into a filiform apex without a knob.....

A. attenuatum

Arisaema agasthyanum Sivad. \& C.S.Kumar, Aroideana 10(4): 19. 1987; Mohanan \& Sivad., Fl. Agasthyamala 756. 2002; Gusman \& L.Gusman, Gen. Arisaema, ed. 2. 357. 2006; Kottaim. \& R.Ganesan, Ethnobot. Leaflets 12: 388. 2008. Type: INDIA, Kerala, Thiruvananthapuram district, Agasthyamala, 1869 m, 15.05.1985, Sathish Kumar TBG \& RI-1350 (K).

Fig. 1

Deciduous, dioecious, succulent, perennial herbs, 50-65 cm tall. Subterranean stem a tuberous corm, subglobose, c. $3.5 \mathrm{~cm}$ diam., $2-3 \mathrm{~cm}$ tall, cream to light green. Roots many arising from the upper side of the corm, extensively long with secondary rootlets; tuberlets often present, surrounding the pseudostem. Cataphylls 3, rarely 4; outer c. 1.5 cm long, acute-obtuse at apex, often degenerated, decidedly mucronate, pale coloured; middle 5-7.5 $\mathrm{cm}$ long, rose to dull green towards the distal end; inner 12-18 cm long, dark coloured with faint greenish brown marks; often a degenerated outer cataphyll also present. Leaf solitary, radiatisect; petiole slender, c. $65 \mathrm{~cm}$ long, light green with faint dull green marks formed of vertical streaks; leaflets (3-5)-7-10, sessile, obovate-elliptic, 10.5-17 cm long, 3.5-5 cm wide, acuminate, margins slightly undulate, minutely praemorse, with a greenish dorsal border, dark green ventrally, pale-glaucous beneath, lateral veins up to 18 pairs, mid-vein flesh coloured mottled with minute rose-purplish spots. Inflorescence dioecious, not exceeding the height of the leaf; peduncle slender, $27-30 \mathrm{~cm}$ long, $0.6-$ $0.8 \mathrm{~cm}$ long thick, exserted by about $6-12 \mathrm{~cm}$ from the sheathing pseudostem, more or less completely enclosed in the petiole in male plants, light green with dull green marks formed of vertical streaks, often pale green without mottling. Spathe $c .25 \mathrm{~cm}$ long; tube of spathe cylindric, slightly funnel shaped towards the mouth region, 5.5-6 cm long, 1.5-2 $\mathrm{cm}$ wide, striped with white and purple; margins of the mouth with auricular extensions; limb c. 19 $\mathrm{cm}$ long, c. $6 \mathrm{~cm}$ wide, galeiform, expanded in the middle, tapering to a purple caudate tail, white 


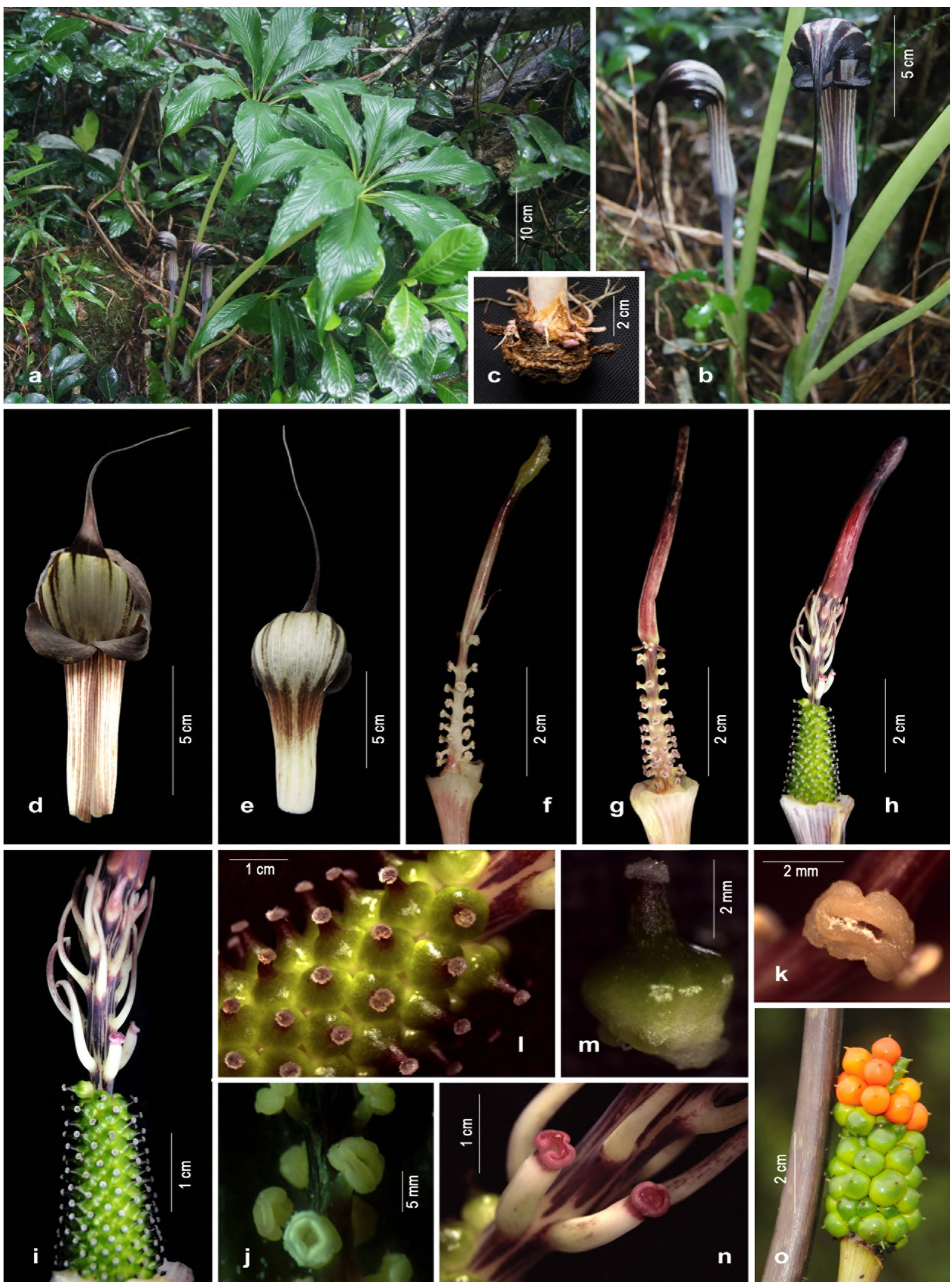

Figure 1. Arisaema agasthyanum Sivad. \& C.S.Kumar: a. Habit; b. Inflorescence; c. Corm; d. Spathe-front view; e. Spathe-back view; f \& g. Male spadix; h. Female spadix; i. Female floriferous region; j \& k. Male flowers-enlarged view; I \& m. Female flowers-enlarged view; $\mathbf{n}$. Neuters with aborted anthers; 0. Fruiting spike. 
towards the base, dark purple distally. Female spadix sessile, $7-7.5 \mathrm{~cm}$ long, c. $0.5 \mathrm{~cm}$ wide, just reaching to the mouth of the tube; female fertile region $2-2.5 \mathrm{~cm}$ long; pistils many, compactly arranged, bottle-shaped, green; ovules 4-6; style short; stigma papillose, white to hyaline; neuters subulate, few, 1.5-2 cm long, scattered below the barren appendix up to $2 \mathrm{~cm}$, upcurved, light green; appendix sub-cylindric, irregularly truncate and shortly stipitate, slightly swollen distally, warted on ageing, purple to green. Male spadix sessile, slender, naked or sometimes one or two neuters present; male fertile region $2-3 \mathrm{~cm}$ long; male flowers stipitate, scattered, 1-3-androus; anthers sessile, cream-white, forming an annular structure with rounded or circumscissile dehiscence, rarely anthers become free. Fruiting spike cylindrical, $c$. $5 \mathrm{~cm}$ long, c. $2.5 \mathrm{~cm}$ wide, borne on an upright peduncle; receptacle cream coloured; berries compactly arranged, green when young, orangered at maturity, apex muticate, 3-6-seeded.

Flowering \& fruiting: May-August.

Habitat: In grasslands, among bushes at an elevation above $1800 \mathrm{~m}$, along with Adiantum sp. (Adiatntaceae), Canthium sp., Hedyotis travancorica Bedd., Psychotria sohmeri Kiehn. (Rubiaceae), Memecylon sp. (Memecylaceae) and Liparis sp. (Orchidaceae).

Distribution: India (southern Western Ghats), endemic.

Specimens examined: INDIA, Kerala, Thiruvananthapuram district, Agasthyamala, 22.05.1901, C.A. Barber 2910 (CAL!); ibid., Athirumala, c. 1200 m, 24.06.1993, N. Mohanan 11452, 11453 (TBGT!); Pongalappara, 1400-1600 m, 15.05.1988, N. Mohanan 9807, 9808 (TBGT!); ibid., c. 1560 m, 11.06.2011, Manudev 4451 (CALI!); ibid., 05.06.2014, Manudev \& Arunkumar 138922 (CALI!); ibid., 07.06.2015, Arunkumar \& Manudev 144919 (CALI!); ibid., 06.07.2015, in fruiting, Arunkumar \& Rajeevan 144916 (CALI!); ibid., 06.07.2015, in flowering, Arunkumar \& Rajeevan 144918, 144919 (CALI!); ibid., 01.08.2015, in fruiting, A.J. Robi s.n.

Notes: Similar to $A$. translucens C.E.C.Fisch., but can be distinguished by its galieform, expanded limb and annulate staminate flowers. Other than this species, annulate staminate flowers are seen only in A. exappendiculatum H.Hara, a species endemic to Nepal.

Conservation status: The population size at the type locality, Pongalappara is very low, consisting of hardly 20 plants. Based on 'Extent of Occurrence' (EOO<100 km²; Criterion B1), 'Area of Occupancy' [Criterion B2: AOO $<10 \mathrm{~km}^{2}$ with Extreme fluctuations in number of subpopulations [sub-criterion 'c (iii)'], and number of mature individuals (Criterion D), A. agasthyanum has been assessed here as 'CRITICALLY ENDANGERED' [CR: B1, B2b(iii \& iv), B2c(iii) \& D] according to IUCN's guidelines (IUCN SPS, 2017).

Arisaema arunachalense A.Nangkar, A.P.Das \& H.Tag, (as A. arunachalensis), Pleione 11(2): 482. 2017. Type: INDIA, Arunachal Pradesh, East Siang District, Pasighat, $560 \mathrm{~m}, 08.05 .2015, A$. Nangkar \& Hui Tag 026 (ASSAM).

Fig. 2

Dioecious, perennial herbs, c. $70 \mathrm{~cm}$ tall. Subterranean stem a corm, 1-2.2 cm long, 2.5-4.3 cm diam., depressed globose. Roots many, from the top of the corm; stolons absent. Cataphylls 2, to $18 \mathrm{~cm}$ long, one short and other long. Leaves 1, held above the inflorescence; petiole 10-70 cm long, terete, white, generally pinkish towards the base, mottled with purple patches and spots; leaflets 5-9, radiate, 14-34 cm long, 3-9.5 $\mathrm{cm}$ wide, broadly obovate-lanceolate, longacuminate (c. $2 \mathrm{~cm}$ long) at apex, base gradually attenuate; slightly unequal in size, pale green above, whitish below, marginal veins extending from base to tip. Sheathing pseudostem $c .18 \mathrm{~cm}$ long, mottled as in petiole. Inflorescence arises just above the cataphylls, 12-18 cm above from the corm; peduncle much shorter than petiole, 25-34 cm long, exserted by 7-10 cm long from the pseudostem, mottled as in petiole, nodding at fruiting. Spathe dull-white on both surfaces; tube of spathe cylindric, funnel-shaped towards mouth, 20.3-23.2 cm long, dull-white with purple longitudinal lines on both surfaces, slightly constricted at the mouth, margins of the mouth dilated to a revolute auricular extension; limb wider than the tube, sagittate-ovate, caudateacuminate at apex, forming a slender tail $(c .5 \mathrm{~cm})$, dull white, densely purple-blotched, sometimes blotches coalescing. Female spadix sessile, 9.5$11.2 \mathrm{~cm}$ long, cylindric with a narrow fertile 

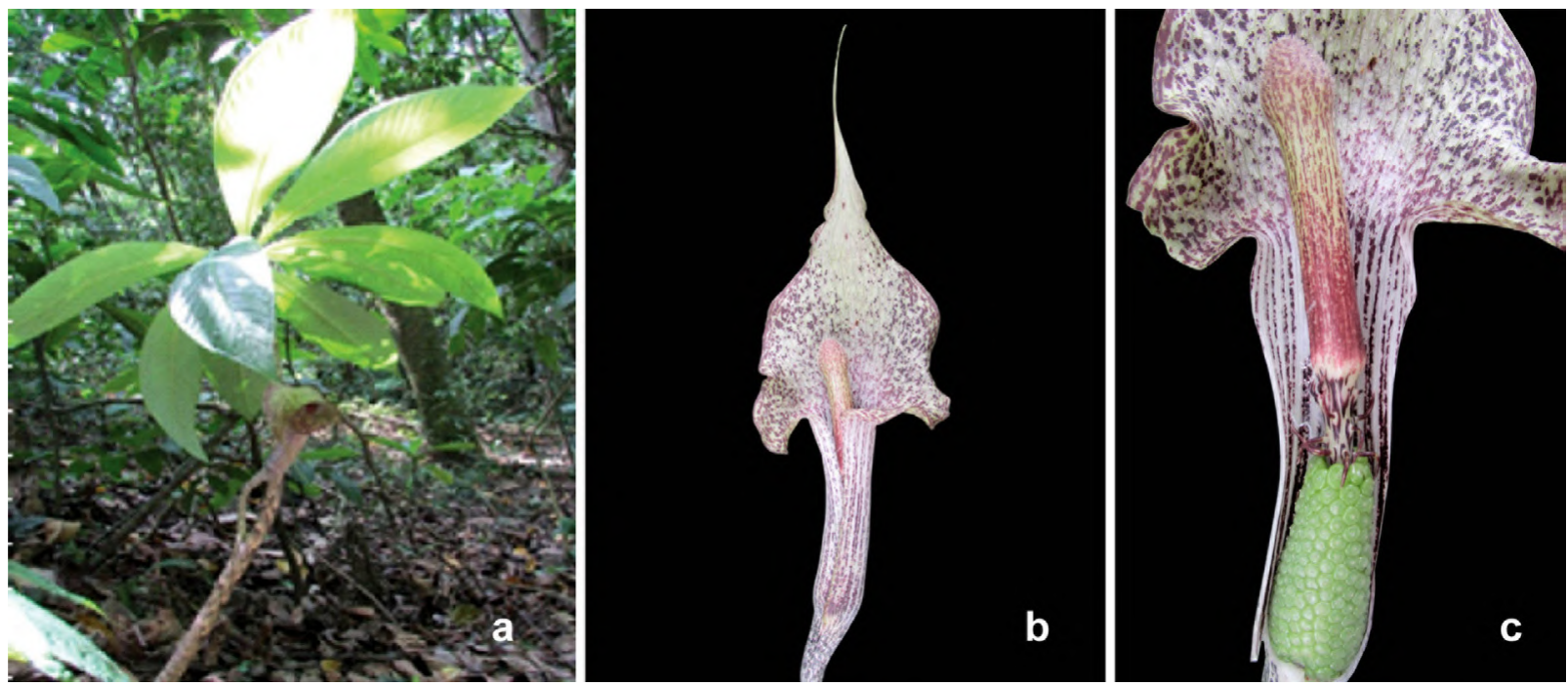

Figure 2. Arisaema arunachalense A.Nangkar, A.P.Das \& H.Tag: a. Habit; b. Inflorescence; c. Female spadix (Images A.P.Das).

region, mottled with purple blotches, sterile zone with 14-17, dark purple subulate neuters; appendix stipitate, cylindric with swollen apex (looks like the tip of drum-stick), dark purple and white mottled, exceeding the mouth of the tube; pistils many, sessile, compactly arranged, ovoid, green, stigma short, continuous, whitish. Male spadix smaller than female, with many pistillodes towards the base, neuters absent, sterile male flowers at the middle and fertile male flowers above; male flowers sessile, scattered at the middle, crowded distally, consisting of 4 or 5 dark purple anthers. Fruiting spike not seen.

Flowering \& fruiting: April-October.

Habitat: On the floor of dense evergreen forests with thick humus at an elevation of 500-700 m.

\section{Distribution: India (North-East Himalayas),} endemic.

Notes: Arisaema arunachalense is close to $A$. echinatum (Wall.) Schott in having an echinate spadix appendix but can be distinguished by its longer pseudostem, densely purple blotched spathe limb and swollen tip of appendix as opposed to very short pseudostem, white striped green or purple spathe limb and obtuse apex of spadix appendix in the latter. This species thrives in tropical or subtropical evergreen forests at elevations $500-700 \mathrm{~m}$ whereas A. ciliatum grows above $2500 \mathrm{~m}$. Authors used the epithet 'arunachalensis' in the protologue. The genus name being in neuter gender, the epithet should be corrected to 'arunachalense'.
The description provided here is taken from the protologue.

Arisaema attenuatum E.Barnes \& C.E.C.Fisch., Bull. Misc. Inf. Royal Gard. Kew 1936(4): 275. 1936; Chatterjee, Bull. Bot. Soc. Bengal 8: 121. 1955; Manilal, Fl. Silent Valley 331. 1988; Sivad. in Manoharan et al., Silent Valley-Whispers of Reason. 233. 1999. Type: INDIA, Kerala, Idukki district, Munnar, s.d., E. Barnes 1193 (K000203014 digital image!).

A. leschenaultii auct. Gusman \& L.Gusman, Gen. Arisaema ed. 2. 392. 2006, pro parte, non Blume 1836.

Fig.3

Deciduous, dioecious, succulent, perennial herbs, 40-65 cm tall. Subterranean stem a tuberous corm, subglobose, 3-5 cm diameter, 2-3 cm tall, smooth or wrinkled, tuberlets often present, surrounding the pseudostem. Roots arising from the upper side of the corm. Cataphylls 3 or 4, acute-obtuse at apex, slightly keeled towards tip, decidedly mucronate; outer 2-3 cm long, pale coloured; middle c. $9 \mathrm{~cm}$ long, light green with brownish-purplish and flesh coloured patches; inner $c .21 \mathrm{~cm}$ long similar to middle-one, dark coloured; often a degenerated outer cataphyll also present. Leaf solitary, radiatisect, emerging after the inflorescence; petiole slender, up to $65 \mathrm{~cm}$ long, light green mottled with brownish-purple patches; leaflets 7-9, sessile, oblong-lanceolate, sometimes oblanceolate, 15-21 cm long, 3.5-4.2 $\mathrm{cm}$ wide, narrowly acute to tapering, margins minutely praemorse, with a purplish dorsal border, 
dark green ventrally, pale dorsally, midvein often mottled with purplish spots. Pseudostem $25-30 \mathrm{~cm}$ long, mottled as in petiole. Inflorescence held below the leaf; peduncle slender, $30-35 \mathrm{~cm}$ long, exserted by about $4-5 \mathrm{~cm}$ from the sheathing pseudostem, dark purplish or green-greenish white. Spathe $6.5-12 \mathrm{~cm}$ long; tube of spathe cylindric, slightly funnel-shaped towards the mouth, $6.5-7 \mathrm{~cm}$ long, $1-1.5 \mathrm{~cm}$ wide, white or greenish white basally and greenish towards the distal end with purplishbrown bands along the length of the tube, bands lighter outside, darker inside; purple bands often absent in male plants where it is replaced by green bands outside; margins of the mouth decidedly revolute; limb, short, triangular, elongatelanceolate, narrowly acuminate to tapering, 2-5 cm long, 1.5-2.5 cm wide, green with a large roundish white patch at base with radiating stellate arms, few purplish markings at the junction of the green and white, tail erect or arching forward and pointing downwards. Female spadix sessile, $8-10$ $\mathrm{cm}$ long, 0.2-0.3 cm thick, exceeding the tube and arching forward; female fertile region $2-2.5 \mathrm{~cm}$ long; pistils many, crowded, sessile, subglobose, green; ovules 2 or 3; style short or absent; stigma papillate, stellate, often with a dark bluish neck; neuters subulate, few, 2-3 mm long, scattered over a distance of 2-3 cm, upcurved, completely purple or off-white with a purple tip; appendix slender or filiform, tapering distally, green or purplish buff towards the base, becomes greenish towards the distal end, often with a warty, purple tip. Male spadix sessile, slender, similar to female, $5.5-8.7 \mathrm{~cm}$ long, $0.3-0.5 \mathrm{~cm}$ thick; male fertile region $2-3 \mathrm{~cm}$ long; male flowers scattered over or crowded at the base, distant above, 2-4-androus; anthers sessile, purple, dehisce by an apical pore; pollens spherical, slightly echinate, purple; neuters usually absent, rarely 1 or 2 present. Fruiting spike not seen.

Flowering: May-June.

Habitat: In grasslands and in shola forests at an elevation above $1200 \mathrm{~m}$, together with $A$. peltatum, A. leschenaultii and A. tortuosum.

Distribution: India (southern Western Ghats), endemic.

Specimens examined: INDIA, Kerala, Idukki district, Devikulam, c. 1800 m, 27.07.1982, N. Sasidharan 4173, 4178 (KFRI!); Lockhurt gap, Munnar-
Poopara road, 23.05.2011, Manudev \& Santhosh Nampy 4430, 4431 (CALI!); ibid., 25.05.2012, Anisha \& Manudev 4563 (CALI!); Mathikettan shola, Aduvizhuntha kudi, 22.11.2014, Syam Radh \& Rajeevan, 137822, 137824 (CALI!); Checkpost to Onnam Thodu, Mathikettan, 22.05.2015, Manudev \& Syam Radh 138959 (CALI!); Choondal, Mathikettan, 23.04.2016, Syam Radh \& Arunkumar 149117 (CALI!); Ettukalichelamaram to Check post, 22.05.2015, Manudev \& Syam Radh 138957 (CALI!); Onnamthode, Mathikettan, 08.05.2016, Syam Radh 137976, 137979 (CALI!); Pallivasal, 24.05.2011, Manudev \& Santhosh Nampy 4438 (CALI!); Sivan Para, Mathikettan, 23.08.2014, Syam Radh \& Prashob 143502 (CALI!); Pothamedu, c. $1100 \mathrm{~m}, 25.07 .2013$, Manudev 135307 (CALI!). Tamil Nadu, Coimbatore district, Anamalai hills, 26.06.1973, R.N. Kayal \& H.N. Tribedi 569 (CAL!).

Notes: Arisaema attenuatum was described by Fischer (1936) from the collections of Professor Edward Barnes from Munnar High ranges. Gusman and Gusman (2006) treated this species as a synonym of $A$. leschenaultii, a common species distributed throughout the Western Ghats showing significant variation. However, it is distinct from the latter in having shorter spathe limb with a basal white spot and slender spadix appendix.

Conservation status: The population size of $A$. attenuatum thriving at the Devikulam and Lockhurt Gap is very scanty with about less than 10 mature individuals; while at the Pallivasal, 25 mature individuals were observed and at the Mathikettan shola National Park about 65 individuals. There are a few specimens at CAL collected from Anamalai hills of Tamilnadu region, not far away from the type locality. Based on 'Extent of Occurrence' (EOO<100 km²; Criterion B1), 'Area of Occupancy' [Criterion B2: AOO $<10 \mathrm{~km}^{2}$ with extreme fluctuations in number of subpopulations [sub-criterion 'c (iii)'], and number of mature individuals (Criterion C), A. attenuatum is assessed here as 'CRITICALLY ENDANGERED' [CR: B1, B2b(iii), B2c(iii) \& C2b.] according to IUCN's guidelines (IUCN SPS, 2017). This species is threatened due to habitat loss mainly by the conversion of forest areas in to tea plantations in Munnar regions.

Arisaema barnesii C.E.C.Fisch., Bull. Misc. Inform. Kew 1933: 342. 1933; Gamble, Fl. Madras 

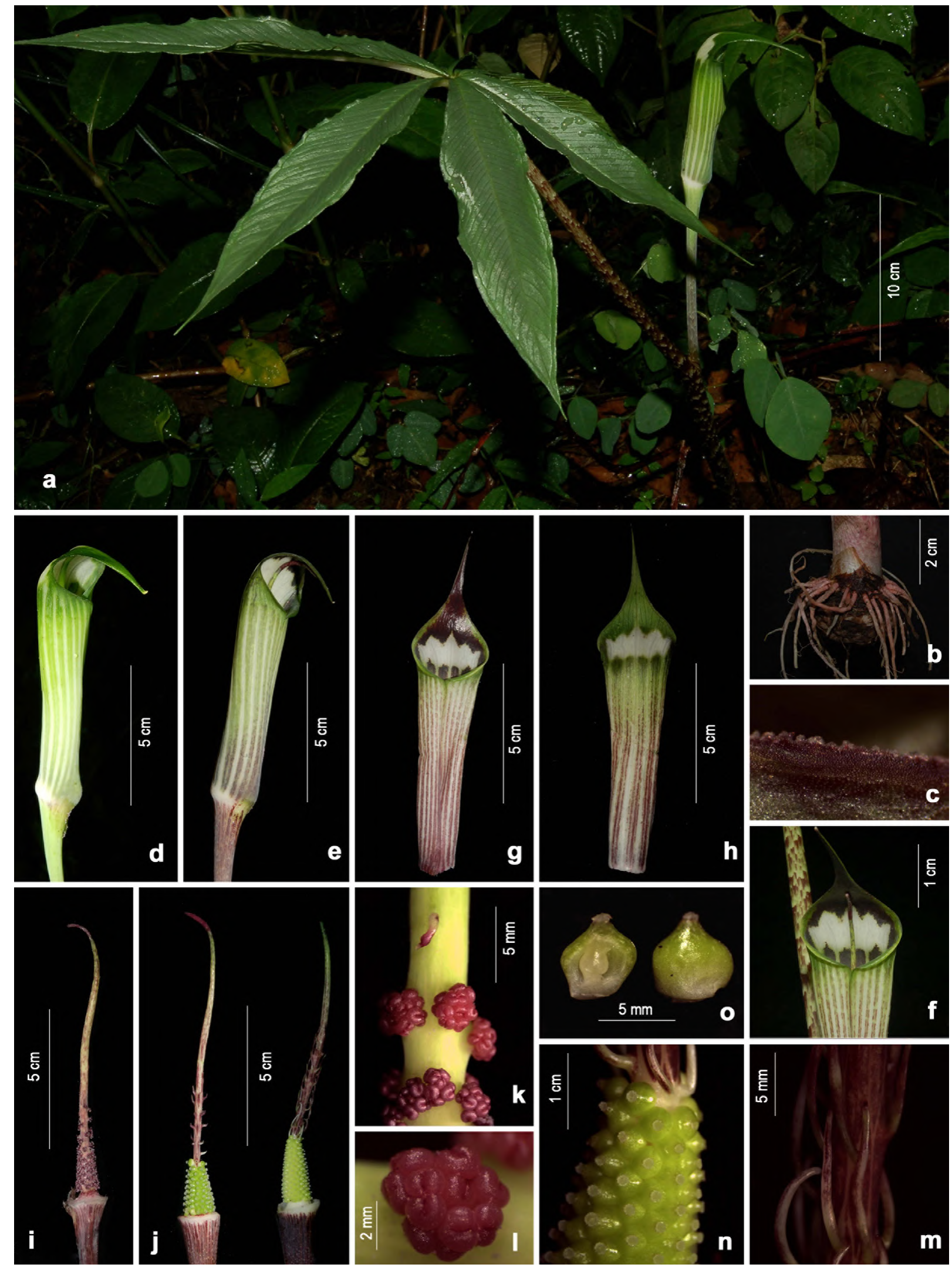

Figure 3. Arisaema attenuatum E.Barnes \& C.E.C.Fisch.: a. Habit; b. Corm; c. Leaf margin-enlarged view; d. Male inflorescence; e. Female inflorescence; f. Mouth of the spathe tube; $\mathbf{g}$. Spathe-front view; h. Spathe-back view; i. Male spadix; j. Female spadices; k. Male floriferous region; I. Male flower-enlarged view; m. Neuters; n. Female flowers; 0 . Pistils. 
3(11): 1891. 1936; Manilal, Fl. Silent Valley 331. 1988; Sivad. in Manoharan et al., Silent ValleyWhispers of Reason. 233. 1999; N.Mohanan \& Sivad., Fl. Agasthyamala 756. 2002. Type: INDIA, Tamil Nadu, Nilgiris district, Kotagiri, Longwood Shola, 20.05.1932, E.Barnes A.R.3b \& c (K, digital images!)

Fig. 4

Deciduous, dioecious, succulent, perennial herbs, about $40-65 \mathrm{~cm}$ tall. Subterranean stem a tuberous corm, subglobose, 3-7 cm diam., 2-5 cm tall, cream to greenish white inside, tuberlets often present, surrounding the pseudostem. Roots arising from the upper side of the tuber. Cataphylls 3 or 4 , acute-obtuse at apex: outer $2-3 \mathrm{~cm}$ long, slightly keeled towards the tip, decidedly mucronate, pale coloured; middle c. $9 \mathrm{~cm}$ long, light green with brownish-purplish and flesh coloured patches; inner c. $21 \mathrm{~cm}$ long similar to middle-one, dark coloured; often a degenerated outer cataphyll also present. Leaf solitary, radiatisect, emerging after the inflorescence; petiole slender, up to $65 \mathrm{~cm}$ long, light green mottled with brownish-purple patches; leaflets 7-9, shortly petiolulate, oblong-lanceolate, sometimes oblanceolate, 15-21 cm long, 3.5-4.2 $\mathrm{cm}$ wide, narrowly acute to tapering, margins minutely praemorse, with a purplish dorsal border, dark green ventrally, pale dorsally, midvein often mottled with purplish spots. Pseudostem $25-30 \mathrm{~cm}$ long, mottled as in petiole. Inflorescence dioecious, held below the level of leaf; peduncle slender, $30-35 \mathrm{~cm}$ long, exserted by about $4-5 \mathrm{~cm}$ from the sheathing pseudostem, dark purplish or greengreenish white. Spathe $6.5-12 \mathrm{~cm}$ long; tube of spathe cylindric, slightly funnel-shaped towards the mouth region, $6.5-7 \mathrm{~cm}$ long, 1-1.5 $\mathrm{cm}$ wide, purplish brown basally and greenish towards the distal end with white or greenish white stripes along the length of the tube, dark purplish inside; margins of the mouth slightly revolute; limb ovate, 3.5-6 cm long, 2.5-3.5 wide, horizontal, or sometimes erect, tapering in to a filiform tail, sometimes terminated by a minute knob, green outside with white stripes, dark carmine, dark purple or green inside with 5 white stripes at the base. Female spadix sessile, c. $7 \mathrm{~cm}$ long, 0.2-0.3 cm thick; female floriferous region 2.5-3 cm long; pistils crowded, sub-globose, green; style short; stigma papillose; appendix narrowly fusiform, widest at the middle, tapering to a short tail with a small minutely warted apical knob, dark- purple or pale below and the apex dark purple, the basal portion with a few narrow ridges; neuters subulate, on the lower third of the appendix, a few laminate ridges above these up to halfway. Male spadix similar to female, slender, 5-6 cm long, male floriferous region $2-3 \mathrm{~cm}$ long; male flowers scattered over or crowded at the base and distant above, 2-7-androus; anthers sessile, purple, dehisce by an apical pore. Fruiting spike not seen.

Flowering \& fruiting: March-September.

Habitat: In shola forests and in evergreen forests at an elevation above $1000 \mathrm{~m}$, associated with $A$. leschenaultii, A. tortuosum, A. tylophorum, etc.

Distribution: India (southern Western Ghats), endemic.

Specimens examined: INDIA, Kerala, Kannur district, Aralam wild life sanctuary, 03.03.2014, flowered in garden, Alfred \& Manudev 4388 (CALI!). Palakkad district, Dhoni hills, 07.07.2012, Prabhu kumar \& Alfred 5078 (CALI!). Thrissur district, Sholayar, 01.05.2011, Manudev \& Alfred 4404, 4412 (CALI!). Wayanad district, Chandanathode, on the way, near Seminary villa, 625 m, 03.05.1979, V.S. Ramachandran 62222 (CAL!); Mandanmala, Vythiri, 29.04.2011, Manudev \& Nikhil Krishna 5254 (CALI!); Vellarimala, 05.04.2013, Robi Jose \& Manudev 135201 (CALI!). Tamil Nadu, Coimbatore district, c. $1005 \mathrm{~m}$ (3300 ft), 30.05.1910, C.E.C. Fischer 1957 (DD!). Nilgiris District, s.loc., s.d., Perottett 1813 (P017050542, digital image!). Longwood shola, Kotagiri, 21.06.2011, Manudev, Prabhu kumar \& Sreeraj 4483 (CALI!). Tirunelveli district, Naterikad, c. 1220 m (4000 ft), 13.02.1913, D. Hooper \& M.S. Ramaswami 38527 (CALI!).

Notes: This species is closely related to $A$. peltatum and $A$. leschenaultii, from them it can be distinguished by its petiolulate leaflets and narrowly fusiform appendix widest at the middle, tapering to a short tail with a small minutely warted apical knob and a ridged basal portion.

Conservation status: This species is known to occur in Nilgiris Biosphere Reserve and adjacent regions. However, not more than 10 mature individuals are observed in each population. Due to the large-scale conversion of forests in to tea and cardamom plantations, gradual decline of the quality of habitat has led to a faster decline of this 


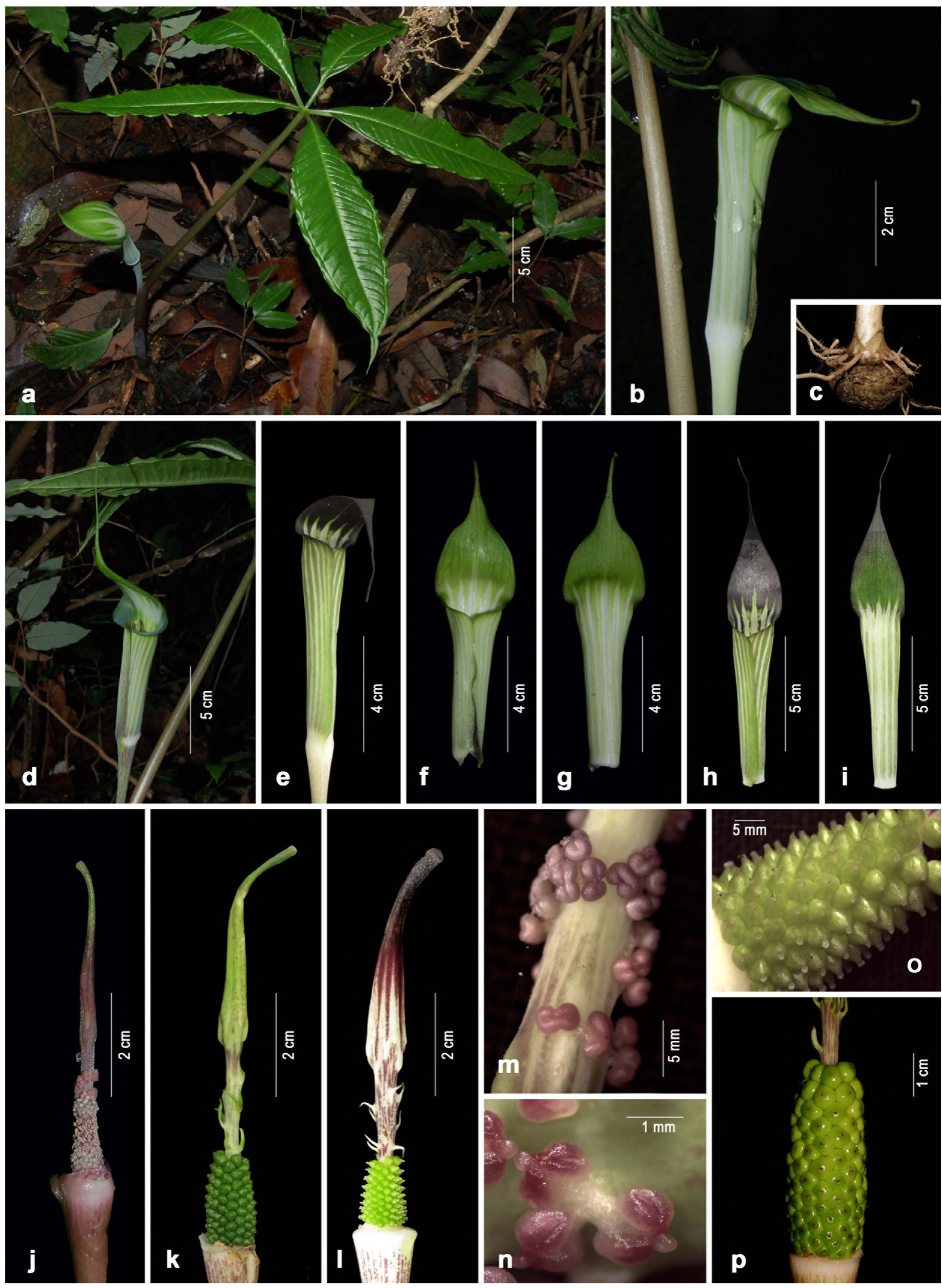

Figure 4. Arisaema barnesii C.E.C.Fisch.: a. Habit; c. Corm; b, d \& e. Inflorescences; f-i. Spathe (f \& h. front view; g \& i. back view); j. Male spadix; k \& I. Female spadices; m. Male floriferous region; $\boldsymbol{n}$. Male flowers-enlarged view; o. Female flowers-enlarged view; $\mathbf{p}$. Young fruiting spike. 
species. Based on Extent of Occurrence (Criterion $\mathrm{B} 1$ : $\mathrm{EOO}>5000 \mathrm{~km}^{2}$ ), continued decline in area of occupancy, quality of habitat (sub-criterion b(ii) \& $\mathrm{b}$ (iii), 'Reduction in population size' (Criterion A1: suspected population size reduction of $\geq 70$ ), decline in area of occupancy, extent of occurrence and/or quality of habitat (sub-criterion '1b'), the effects of introduced taxa and pollutants (sub-criterion 'e'), A. barnesii is assessed here as ENDANGERED [EN: A1, 1b \& e; B1, B2b(ii, iii), B2c(ii, iii, iv) \& D] according to IUCN's guidelines (IUCN SPS, 2017).

Arisaema caudatum Engl. in A.DC. \& C.DC., Monogr. Phan. 2: 559. 1879; Hook.f., Fl. Brit. Ind. 6: 507. 1893; Woodrow, J. Bombay Nat. Hist. Soc. 13(3): 428. 1901; T.Cooke, Fl. Bombay 1: 821. 1903; Engl., Pflanzenr. IV. 23F(73): 183. 1920; Blatt., J. Asiatic Soc. Bengal 26: 364. 1931; J. Bombay Nat. Hist. Soc. 35: 19. 1931; Chatterjee, Bull. Bot. Soc. Bengal 8: 129. 1955; R.S.Rao \& K.K. Ahuja, Bull. Bot. Surv. India 11(3-4): 450. 1969; Sandhya Deshpande et al., Fl. Mahabhaleshwar 2: 615. 1995; S.R.Yadav \& Sardesai, Fl. Kolhapur Dist. 517. 2002. Type: INDIA, Concan, s.d., Stocks s.n. (P01750624 digital image!).

A. longecaudatum Blatt., J. Asiatic Soc. Bengal 26: 362. 1931; J. Bombay Nat. Hist. Soc. 35: 20. 1931; Chatterjee, Bull. Bot. Soc. Bengal 8: 128. 1955. Type: INDIA, Maharashtra, Mahabhaleshwar, 07.1925, Blatter P10 (BLAT).

A. leschenaultii auct. Gusman \& L.Gusman, Gen. Arisaema ed. 2. 392. 2006, pro parte, non Blume, 1836.

Figs. 5 \& 6

Deciduous, dioecious, succulent, perennial herbs, c. $70 \mathrm{~cm}$ tall. Subterranean stem a tuberous corm, subglobose, 2-2.5 × 3-3.5 cm, wrinkled, creamwhite, few tuberlets often surrounding the pseudostem. Roots many, from the upper side of the corm. Cataphylls 3 or 4 , obtuse-orbicular at apex, slightly keeled and mucronate; outer 3.5-6 $\mathrm{cm}$ long, pale-brown to purple-brown with faint brown-reddish mottling; middle 7.3-12 cm long, completely enclosing the pseudostem, green, sometimes cylindric below up to $3 \mathrm{~cm}$ long; inner 15.2-29 cm long, dark brown mottled, cylindric below, up to $12 \mathrm{~cm}$ long; sometimes a pale coloured outer cataphyll c. 2.5-3 cm long may be present together with another degenerated cataphyll. Leaf solitary, rarely 2, radiatisect, opens usually before inflorescence or emerges together; petiole up to 68 cm long, green, pale-brown mottled; leaflets 5-8, sub-sessile or petiolulate, elliptic, ovate-obovate, 15-18 cm long, 6.2-9.5 cm wide, base cuneate, long caudate, 3-9 cm long, margins entire, dark green ventrally, pale dorsally. Pseudostem $21-43 \mathrm{~cm}$ long, $1-3 \mathrm{~cm}$ thick, mottled as in petiole. Inflorescence matures after the emergence of leaf, held below or at the level of leaf; peduncle 36.5-64 cm long, pale to dark brown mottled, greenish distally, sometimes green all over without any mottling, exserted by $11-21 \mathrm{~cm}$ long from the pseudostem. Spathe 20-29 cm long; tube of spathe cylindric, slightly funnel-shaped towards the mouth, $6-8 \mathrm{~cm}$ long, 1.2-2 cm wide, slightly constricted at the distal end before the mouth, green with whitefaint lines along the veins, whitish towards the mouth; margins of the mouth dilated, revolute; limb, ovate-lanceolate, $13.5-21 \mathrm{~cm}$ long, 3.5-4.5 $\mathrm{cm}$ wide, narrowly acuminate to caudate, tapering in to a slender tail up to 11-15 cm long, green-dull green all over with white to pale stripes along the veins, arched over and drooping. Female spadix sessile, $7-8 \mathrm{~cm}$ long, $0.4-0.8 \mathrm{~cm}$ thick; fertile region narrow of $2-2.5 \mathrm{~cm}$ long, followed by very few neuters; appendix decidedly stipitate with a slight constriction at the base after neuters, reaching the mouth of the tube or just exceeding, blunt at apex, slightly swollen and rugose, green to light green; neuters subulate, sometimes forked, very few, 2-3 $\mathrm{mm}$ long, scattered, upcurved, green; pistils many, compactly arranged, globose or urn-shaped with rhomboid margins, green; ovules 6-14, white; stigma papillate, stellate, sessile; often a few sterile male flowers also seen. Male spadix sessile, similar to female, slender, $c .7 \mathrm{~cm}$ long, $0.3-0.5 \mathrm{~cm}$ thick; fertile region narrow, $2-2.5 \mathrm{~cm}$ long; male flowers scattered over or crowded at the base and distant above, sessile or decidedly stipitate, consisting of 2-5-androus; anthers sessile, cream-white or pale purple with a terminal mucro, dehisce by an apical pore; neuters very few, subulate-echinate, 2-3 cm long, often forked, pale green. Fruiting spike cylindrical, c. $6 \mathrm{~cm}$ long, c. $3 \mathrm{~cm}$ wide; borne on an upright peduncle; receptacle cream; berries globose, compactly arranged, green, turns yellow to red at maturity, 5-8-seeded.

Flowering \& fruiting: June-October. 


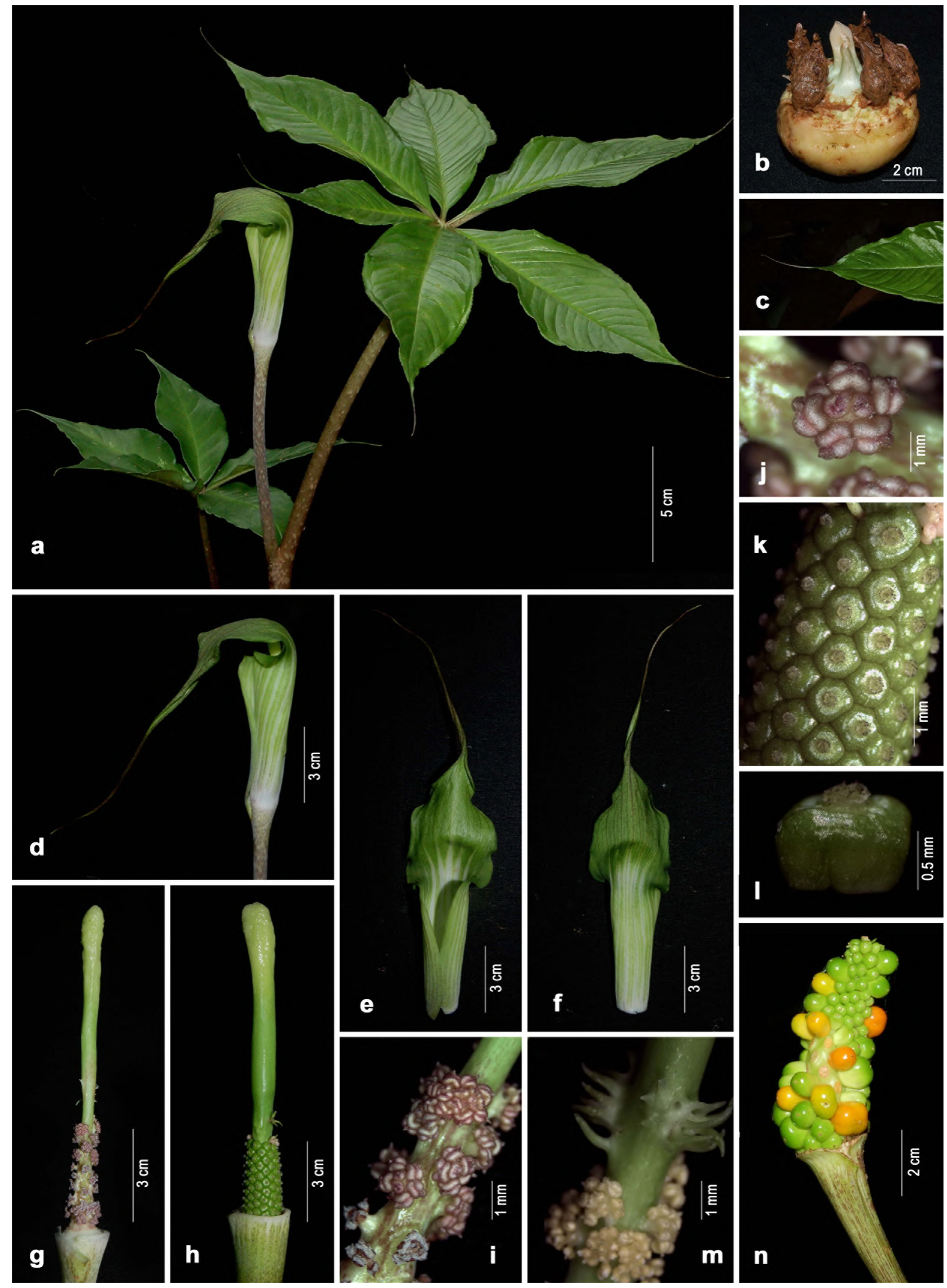

Figure 5. Arisaema caudatum Engl.: a. Habit; b. Corm; c. Leaf tip; d. Inflorescence; e. Spathe-front view; f. Spathe-back view; g. Male spadix; h. Female spadix; i. Male floriferous region; j. Male flowers-enlarged view; k. Female floriferous region; I. Pistil; m. Neuters with aborted anthers; $\boldsymbol{n}$. Fruiting spike. 


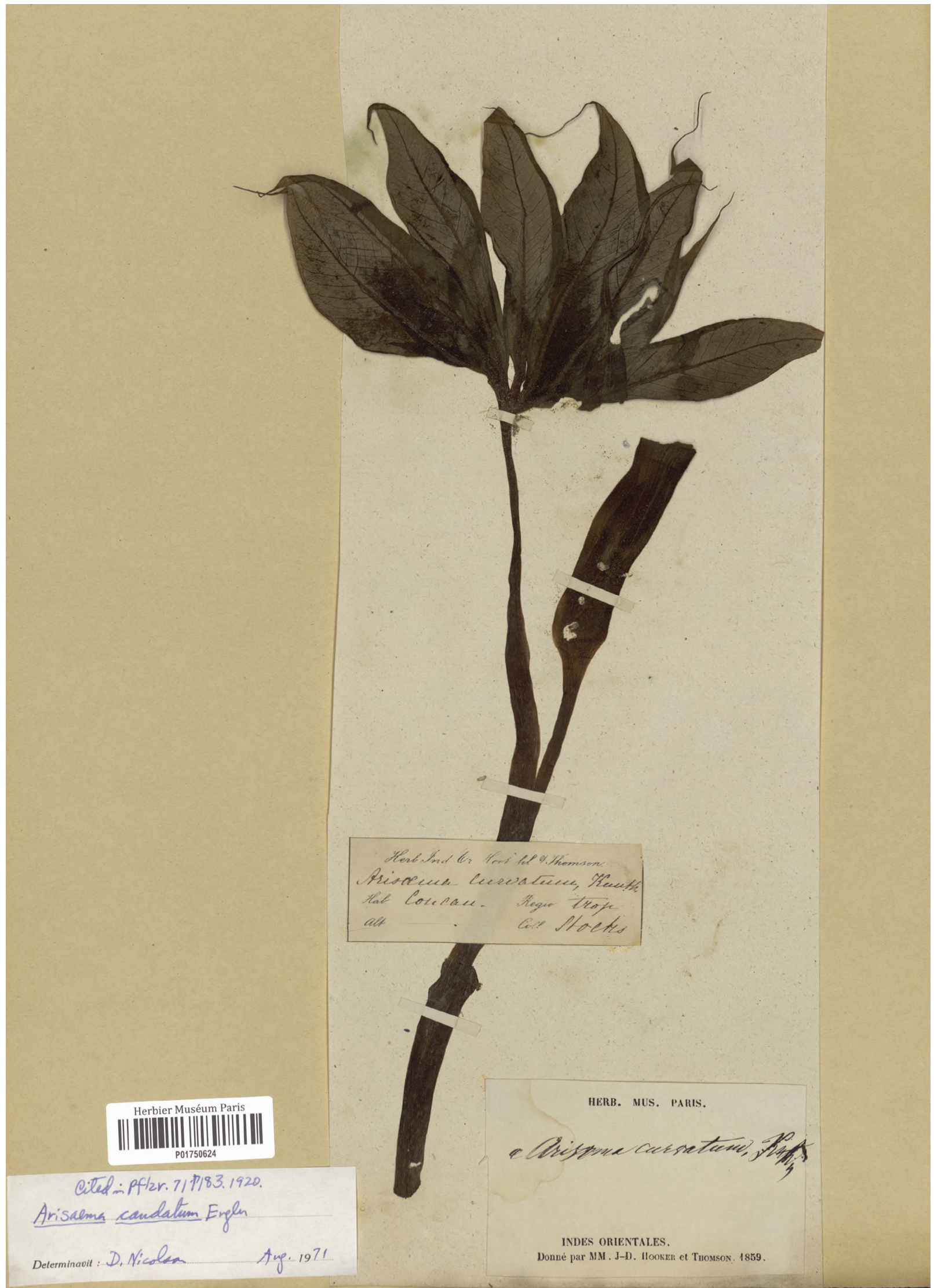

Figure 6. Holotype of Arisaema caudatum Engl. [Stocks s.n. (P01750624)] @ Muséum National d'Histoire Naturelle, Paris. 
Habitat: In semi-evergreen forests, near grasslands at an elevation above $300 \mathrm{~m}$, along with $A$. murray $i$, A. ghaticum, A. sahyadricum, A. sivadasanii and $A$. tortuosum.

Distribution: India (northern Western Ghats), endemic.

Specimens examined: INDIA, Maharashtra, Satara district, Kas, 08.1992, M.P. Bachulkar \& Cholekar 3215 (SUK!). Sindhudurgh district, AmboliChaukul road (cultivated in St. Joseph's College Botanical Garden), 07.07.2012, Manudev \& Santhosh Nampy 5010A (CALI!); ibid., 07.07.2012, Manudev \& Santhosh Nampy 5008A (CALI!); ibid., 27.06.2012, Manudev \& Santhosh Nampy 5031A, B (CALI!).

Notes: This species was described from a badly dried specimen, as said by Engler (1879) himself in his Monographiae Phanerogamarum. Hooker (1893) gave a description based on an illustration of Stocks who had seen this plant from Concan regions. Though incomplete, the descriptions of Hooker and Engler were adopted by the subsequent workers. Subsequently, Blatter (1931) described another species, $A$. longecaudatum, from Mahabhaleshwar in Maharashtra. Rao and Ahuja (1969), proposed a neotype for A caudatum, and merged $A$. longecaudatum as a synonym. However, the original sheet used by Engler to describe this taxon was relocated during the present study from Muséum National d'Histoire Naturelle, Paris, hence supersedes this neotype. Arisaema caudatum is closely related to $A$. leschenaultii, but can easily be identified by its caudate leaves and long tailed spathe limb.

Arisaema ciliatum H.Li var. liubaense Gusman \& Gouda, Blumea 44: 39. 1999; Manudev et al., Pleione 9(1): 229. 2015. Type: Originally from CHINA, Szechuan (Sichuan) Province, near Liuba, area of Mt. Minya Konka, 3600 m, C. Teune 369, subsequently raised by Gusman, 09.05.1989 (U, digital images!).

Fig. 7

Deciduous, dioecious, succulent, perennial herbs, c. $55 \mathrm{~cm}$ tall. Subterranean stem a tuberous corm, globose to subglobose, $2-3 \mathrm{~cm}$ diam., $1.5-2.5 \mathrm{~cm}$ tall, cream-white, stoloniferous. Roots many, from the upper side of the corm, white. Cataphylls 2 or 3 , obtuse-orbicular at apex, mucronate; outer c. 2.5 $\mathrm{cm}$ long, pale to white or purplish distally; middle
8-12.5 cm long, pale to white below, pink to purplish above; inner $17-30 \mathrm{~cm}$ long, pale purple or pink, brown or greenish brown, not mottled. Leaf solitary, radiatisect, usually unfolds with the emergence of inflorescence; petiole up to $55 \mathrm{~cm}$ long, $0.5-0.7$ $\mathrm{cm}$ thick, pale to dark greenish brown, greenish distally, not mottled; leaflets 7-12, sessile, narrow, linear to oblong-elliptic, 7-19.5 cm long, 2-3.8 cm wide, long acuminate at apex and prolonged in to c. $3.5 \mathrm{~cm}$ long tail, base gradually cuneate, margins entire, often wavy or undulate, pale-dark green ventrally, glaucous dorsally. Pseudostem 27.5-40 $\mathrm{cm}$ long, $0.7-1.5 \mathrm{~cm}$ wide, coloured as in petiole. Inflorescence held below the leaf; peduncle 32-45 $\mathrm{cm}$ long, green or pale to dark brownish green, exserted by $c .5 \mathrm{~cm}$ from the pseudostem. Spathe 17$25.5 \mathrm{~cm}$ long with a tail up to $15 \mathrm{~cm}$ long; tube of spathe cylindric, funnel-shaped towards the mouth, 5-6 cm long, 1-2 cm wide, pale green to brownish green, pale to white striped along the veins; margins of the mouth strongly recurved, not ciliate; limb ovate-lanceolate, 5.5-6 cm long, 4.5-5.7 cm wide, wider than tube, acute-acuminate and prolonged in to a slender tail, 5-15 cm long, purplish-brown to carmine, with conspicuous white to pale green stripes along the veins ending in an anastomosis, horizontal, arched over and curved down with tails drooping. Female spadix sessile, $6.5-7.5 \mathrm{~cm}$ long, cylindric, well exserted from the tube; fertile region narrow, 2-2.5 cm long, followed by a few neuters; appendix cylindric, 4-5.5 cm long, 0.6-0.8 $\mathrm{cm}$ thick, constricted or truncate at the base after neuters, rounded and smooth at apex, green to light green; neuters subulate, a few, 0.3-0.5 cm long, upcurved, green; pistils many, sessile, compactly arranged, ovoid or bottle-shaped, green; ovules 1-4, white; style short; stigma papillate, stellate, white. Male spadix similar to female, slender, 5-6.5 $\mathrm{cm}$ long, $0.6-0.7 \mathrm{~cm}$ thick; fertile region narrow $1.8-2 \mathrm{~cm}$ long, pale green to green; neuters usually absent; male flowers scattered over or crowded at the base and distant above, stipitate, 2-4-androus; anthers cream, dehisce by an apical round to oblong pore. Fruiting spike cylindrical, c. $6.5 \mathrm{~cm}$ long, c. 2.5 $\mathrm{cm}$ wide, borne on a nodding peduncle; receptacle cream coloured; berries compactly arranged, green when young, orange-red at maturity, 1-4 seeded.

Flowering \& fruiting: May-July.

Habitat: As an under growth in evergreen forests or 


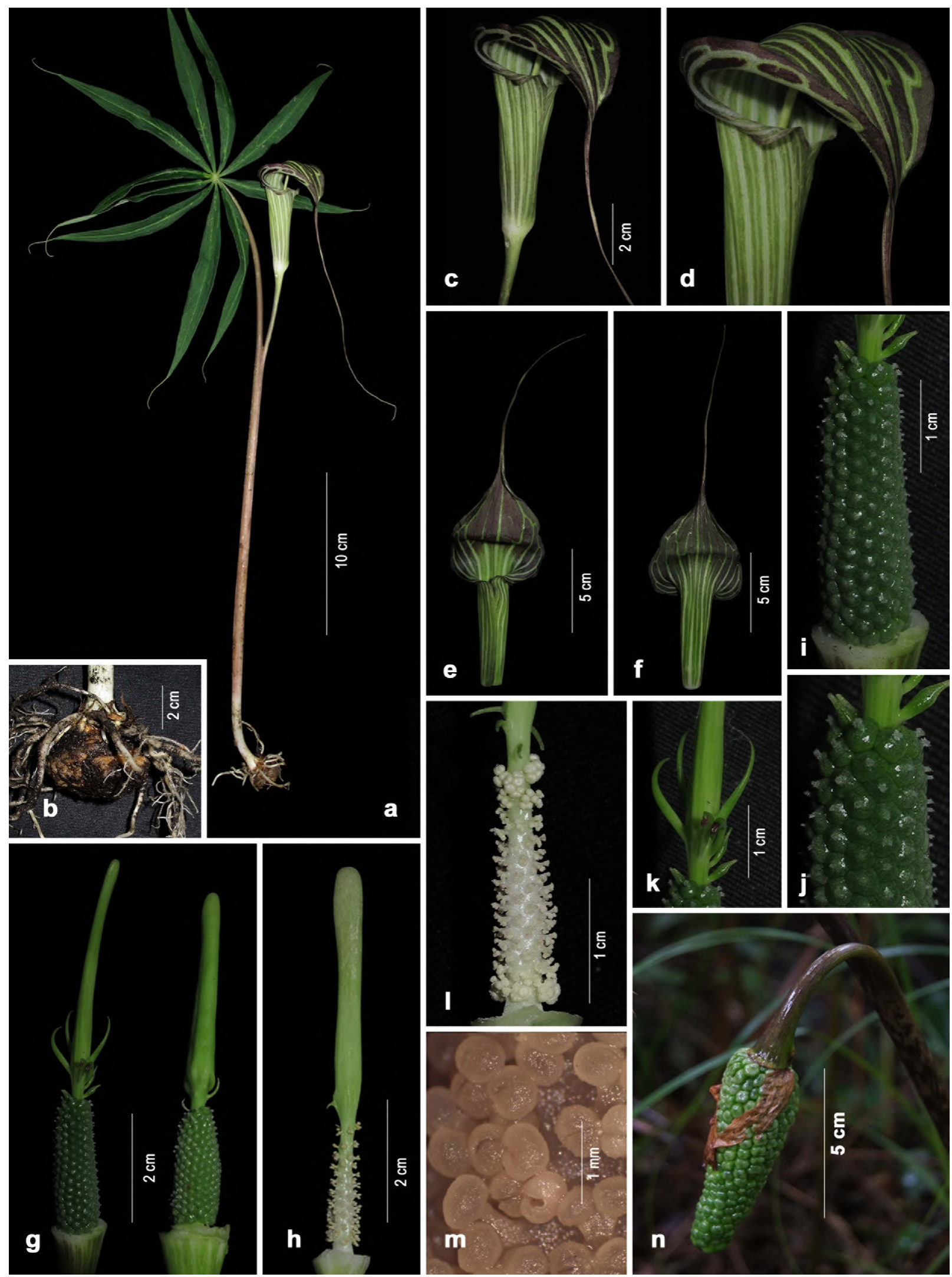

Figure 7. Arisaema ciliatum H.Li var. liubaense Gusman \& Gouda: a. Habit; b. Corm; c. Inflorescence; d. Mouth portion enlarged; e. Spathe-front view; f. Spathe-back view; g. Female spadices; h. Male spadix; i. Female floriferous region; j. Female flowers-enlarged view; k. Neuters; I. Male floriferous region; $\mathbf{m}$. Male flowers-enlarged view; $\mathbf{n}$. Fruiting spike. 
on the edges, in humid semi-shady conditions or along streams, often found along with $A$. fraternum, A. nepenthoides, Cautleya spicata (Smith) Baker (Zingiberaceae), etc.

Distribution: India (North-East Himalayas) and China (Sichuan).

Specimens examined: INDIA, Meghalaya. East Khasi Hills district, Laitryngew, on the way to Cherrapunjee, $1684 \mathrm{~m}, 10.05 .2013$, in flowering, Manudev \& Santhosh Nampy 135220 (CALI!); ibid., 22.07.2014, in fruiting, Manudev 139883 (CALI!).

Notes: Manudev et al. (2015) recently reported this species from India. Gouda and Gusman (1999) described var. liubaense based on the plants grown from the corms received from Michael Hoog (Dutch Gardener), which was originally supplied by Carla Teune, who collected it from Liuba (China) in 1981. Though collected from a Dutch nursery, in the protologue, authors cited the location and collection date as near Liuba, area of Mt. Minya Konka (Gonga Shan) Szechuan (Sichuan) Province, China, at $3600 \mathrm{~m}$ elevation on 15.09.1981. The information on the type specimen also reiterates the same. Dr. Kanchi N. Gandhi (Nomenclatural Registrar, Harvard University, personal communication) opined that the collection details provided in the protologue by Gouda \& Gusman (l.c.) had to be clarified since the type specimens were actually raised in the author's garden.

Arisaema ciliatum var. liubaense is closely related to A. consanguineum in general morphological features but can be distinguished by stoloniferous corms and purple-brown or carmine spathe limb with conspicuous white to greenish-white stripes along the veins ending in an anastomosis as opposed to a proliferous corm and usually greenish spathe limb without white stripes. This variety is also allied to A. erubescens but can be readily distinguished by an erect fruiting peduncle and a pink spathe limb that is shorter than the tube, with an acuminate apex without a long drooping tail.

Arisaema concinnum Schott, Bonplandia 7: 27 (1859), Prodr. Syst. Aroid. 50. 1860; Oliv., Curtis's Bot. Mag. 97: t. 5914. 1871; Engl. in A.DC \& C.DC, Monogr. Phan. 2: 555. 1879; Hook.f., Fl. Brit. India 6: 505. 1894; N.E.Br., J. Linn. Soc., Bot. 18: 254. 1881; Chatterjee, Bull. Bot. Soc. Bengal
8: 122. 1955; H.Hara, Fl. East. Himal. 350. 1971; A.S.Rao \& D.M.Verma, Bull. Bot. Surv. India 18: 17. 1976(1979); Gusman \& L.Gusman, Gen. Arisaema ed. 2. 365. 2006. Type: INDIA, Sikkim, 6000-10000 ft, s.d., J.D. Hooker s.n. (K000203005 digital image!; iso CAL!).

A affine Schott, Bonplandia 7: 27. 1859; Prodr. Syst. Aroid. 51. 1860. A. concinnum var. affine (Schott) Engl. in A.DC. \& C.DC., Monogr. Phan. 2: 557. 1879. Lectotype (designated here): INDIA, Sikkim, 6000-10000 ft, s.d., J.D. Hooker s.n. (K000203008 digital image! excluding the pistils).

A.alienatumSchott,Bonplandia7:26.1859,Prodr.Syst. Aroid. 45. 1860. A. concinnum var. alienatum (Schott) Engl., Pflanzenr., IV, 23F: 178 (1920). Lectotype (designated here): INDIA, Uttarakhand, Garwahl, June 1845, T. Thompson s.n. (K000203002A digital image!)

Figs. 8-11

Deciduous, dioecious, succulent, perennial herbs, c. $95 \mathrm{~cm}$ tall. Subterranean stem a tuberous corm, depressed globose-subglobose, 2-5.4 cm diam., $1-3.5 \mathrm{~cm}$ tall, smooth or wrinkled, cream-white or brownish, stoloniferous. Roots many, pale brown to rose, from the upper side of the tuber. Cataphylls 3 or 4 , acute or obtuse at apex, mucronate; outer c. 2.5-7.5 cm long, pale to white often blushed with rose; middle $5.5-15 \mathrm{~cm}$ long, pale brown to pale rose, faintly mottled; inner $16-30 \mathrm{~cm}$ long, enclosing the pseudostem, pale rose, pale to dark brown, faintly mottled, sometimes cylindric below; often an outer pale-hyaline cataphyll $1-3 \mathrm{~cm}$ long also seen. Leaf solitary, radiatisect, usually unfolds completely before the emergence of inflorescence or together; petiole $38-95 \mathrm{~cm}$ long, $0.5-1.5 \mathrm{~cm}$ thick, pale green to greenish white above, rose to brown tinged below, not mottled; leaflets 5-8, sessile, elliptic-oblanceolate, $15.5-28.5 \mathrm{~cm}$ long, 3-6.8 cm wide, long-acuminate, margins entire, often wavy or undulate, dark green ventrally, pale dorsally. Pseudostem 13.5-29 cm long, $1.5-2.5 \mathrm{~cm}$ wide, wrapped by cataphylls, pale to dark green. Inflorescence held below the level of leaf; peduncle 29-63 cm long, light green, pale green, not mottled, exserted by $13-15.5 \mathrm{~cm}$ long from the pseudostem; Spathe 16-24.5 cm long; tube of spathe cylindric, funnel-shaped towards the mouth, $6-8.5 \mathrm{~cm}$ long, $1.5-2 \mathrm{~cm}$ wide, pale green-green, or pale purple with white-pale stripes along the veins; margins of the mouth slightly dilated to a revolute auricular 


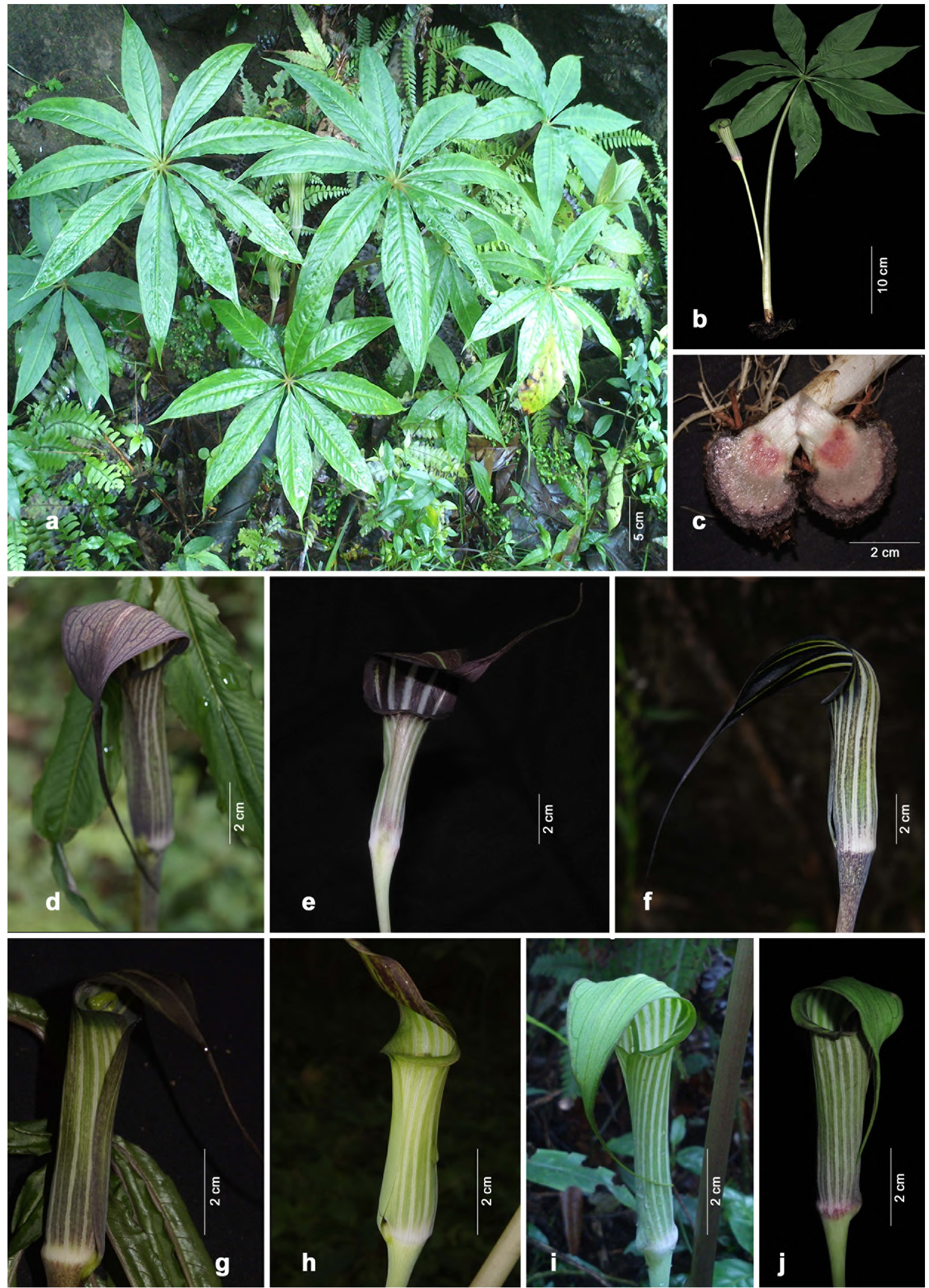

Figure 8. Arisaema concinnum Schott.: a \& b. Habit; c. Corm. d-j. Inflorescences showing variations in their colour 


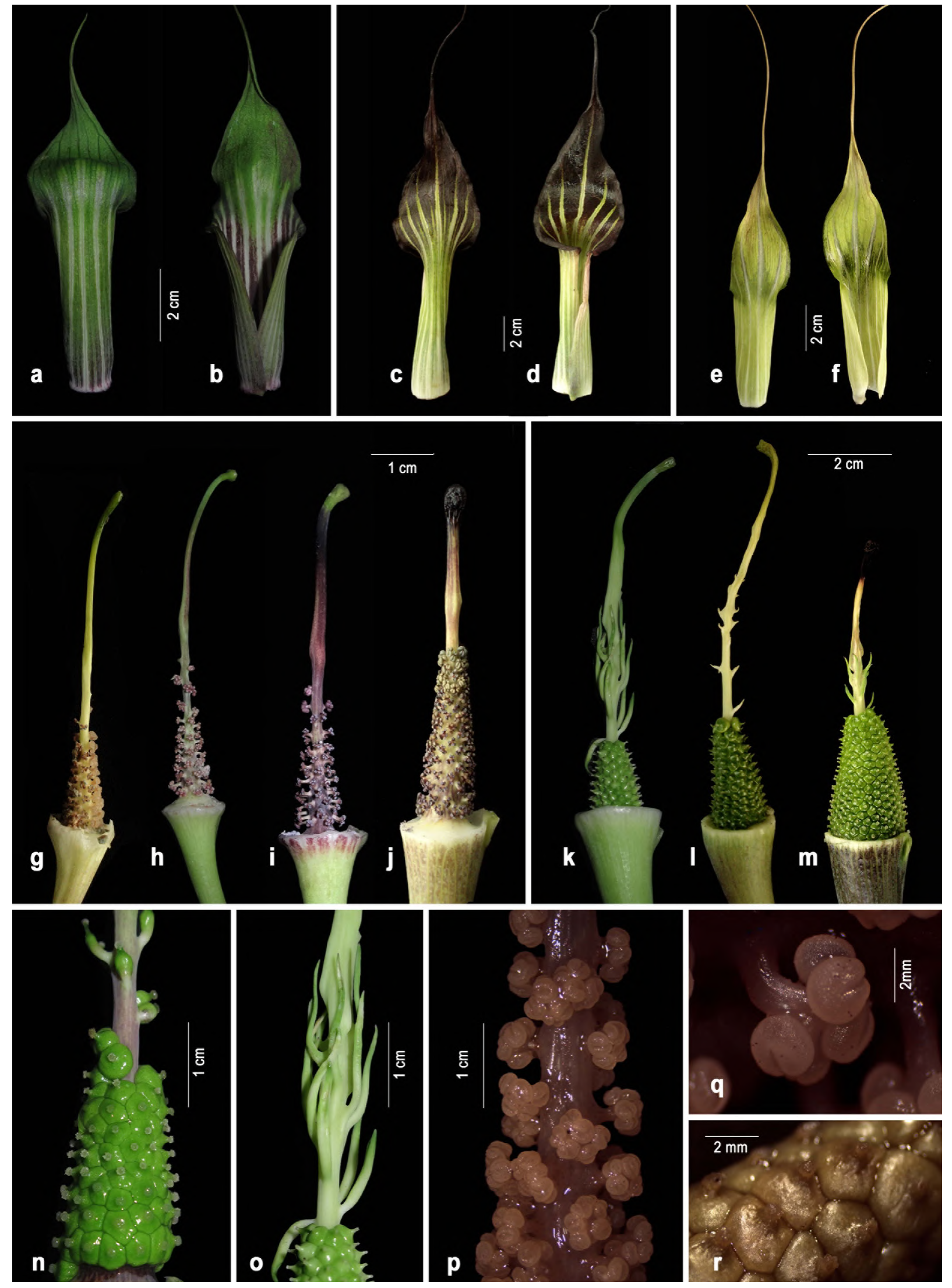

Figure 9. Arisaema concinnum Schott: a-f. Spathes (a,c, e back view; b,d,f front view); g-j. Male spadices; k-m. Male spadices; $\mathbf{n}$. Female floriferous region; $\mathbf{0}$. Neuters; $\mathbf{p}$. Male floriferous region; q. Male flowers-enlarged view; r. Female flowers-enlarged view. 
K.M. Manudev et al. 137

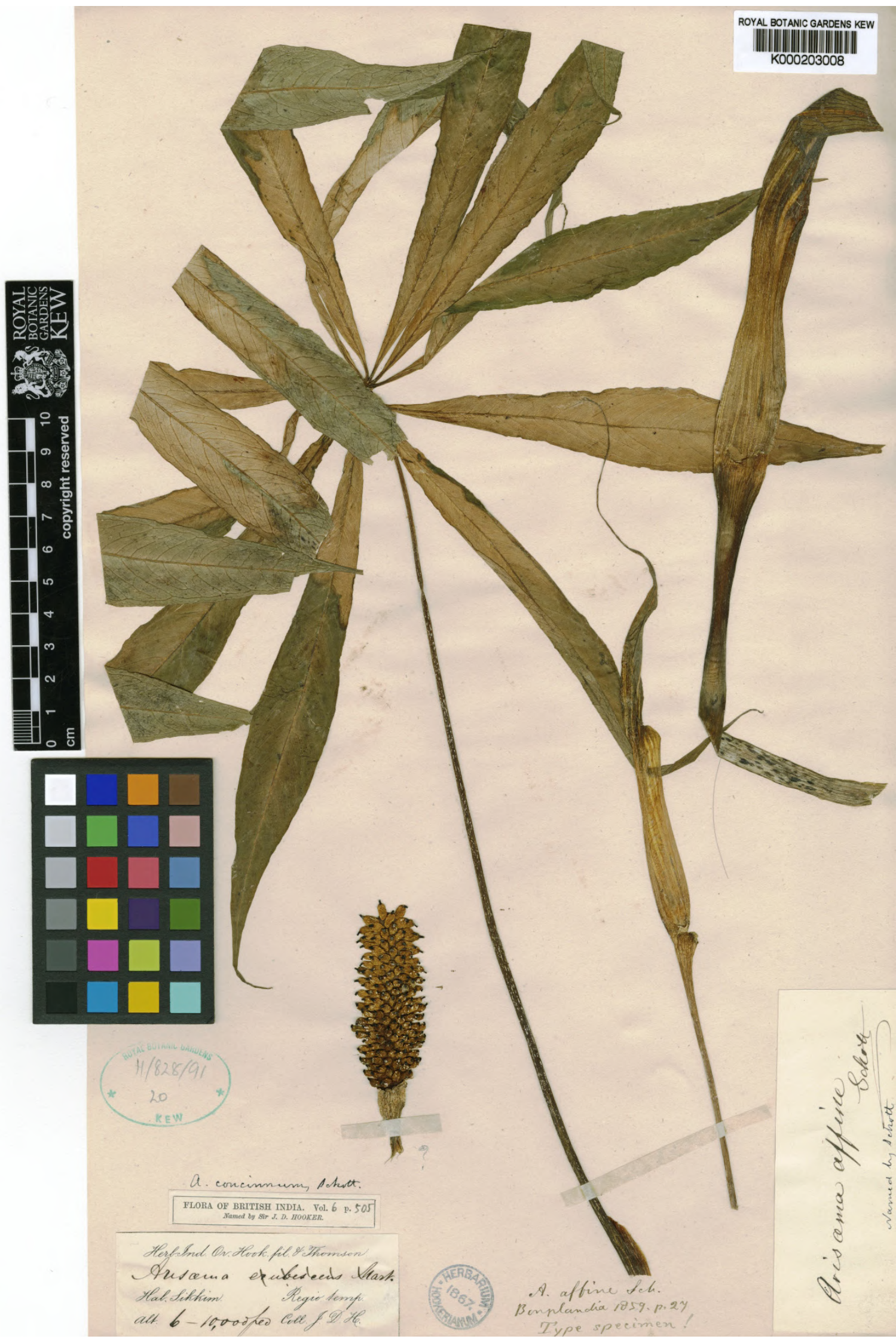

Figure 10. Lectotype of Arisaema affine Schott [J.D. Hooker S.n. (K000203008)] @ The Board of Trustees of the Royal Botanic Gardens, Kew. 


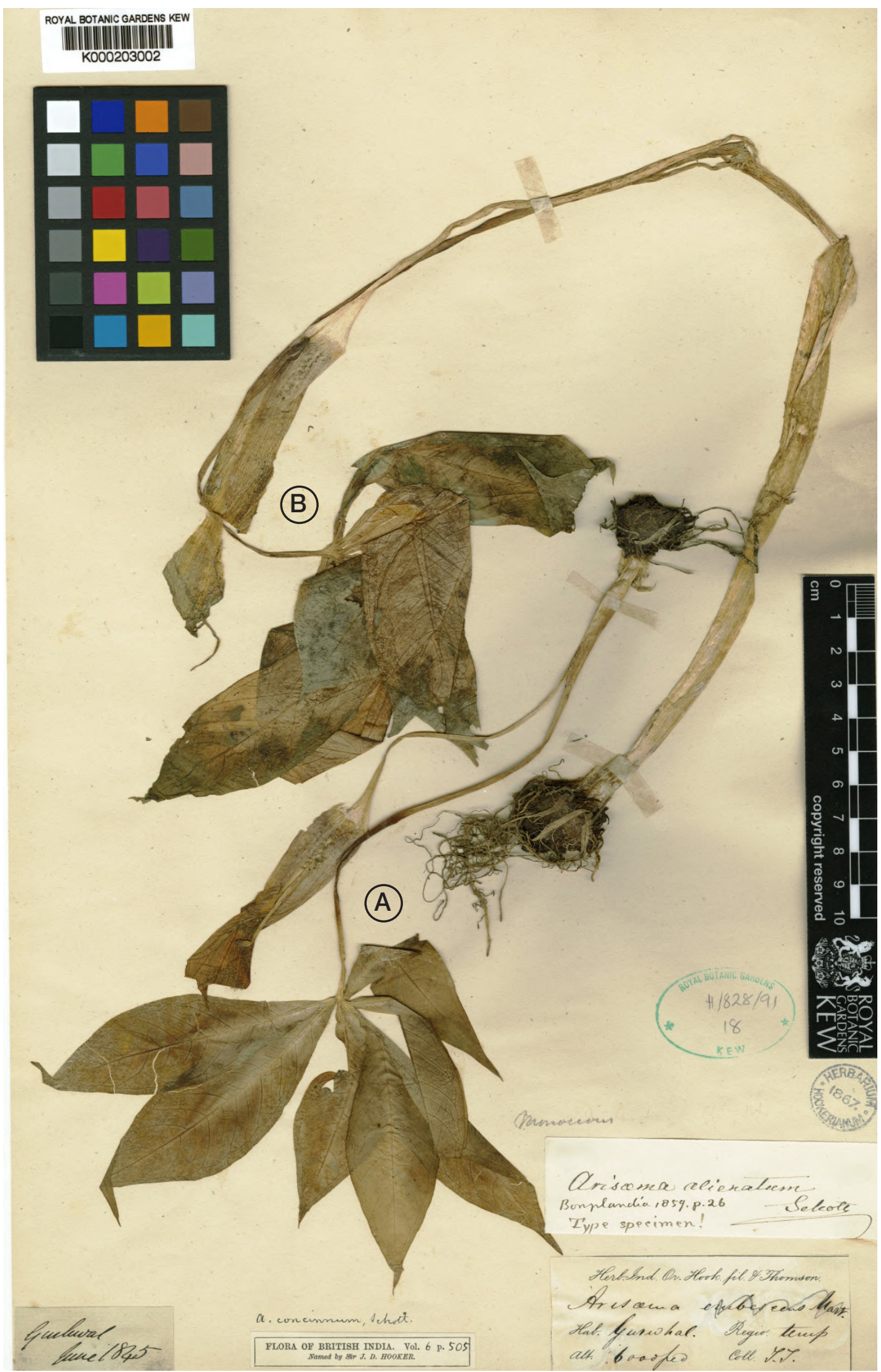

Figure 11. Lectotype of Arisaema alienatum Schott [T. Thompson s.n. (K000203002)] @) The Board of Trustees of the Royal Botanic Gardens, Kew. 
extension; limb, ovate-lanceolate, 10-16 cm long, $3.3-5.2 \mathrm{~cm}$ wide, acuminate with a long tail 5-9 $\mathrm{cm}$ long, green, purple to dark brown all over with white to pale greenish white stripes along the veins, arched over and drooping. Female spadix sessile, $c$. $10 \mathrm{~cm}$ long, $0.3-0.4 \mathrm{~cm}$ thick, slender, unevenly angled with a fertile region of $2-4 \mathrm{~cm}$ at the base, followed by a few neuters; pistils many, sessile, compactly arranged, globose, sometimes angled owing to the compact arrangement, green; ovules 3-5; style short; stigma papillate, stellate, peltate; neuters subulate, a few, $0.5-1.5 \mathrm{~cm}$ long, scattered, upcurved, green; appendix decidedly stipitate with a slight thickening at the base after neuters, reaching the mouth of the tube or just exceeding, slender and gradually tapering, green to light green, apex blunt-truncate, often subcapitate-capitate and purplish-dark brown. Male spadix sessile, similar to female, $4.5-7 \mathrm{~cm}$ long, $0.3-0.4 \mathrm{~cm}$ thick; fertile region narrow, $1.5-2.5 \mathrm{~cm}$ long; neuters usually absent or very few, as small protuberance; male flowers scattered over or crowded at the base and distant above, sessile or stipitate, 2-4-androus; anthers sessile, purple, dehisce by an apical pore. Fruiting spike cylindrical, c. $8.5 \mathrm{~cm}$ long, 3-4 $\mathrm{cm}$ wide, borne on an upright peduncle; berries compactly arranged, rounded at apex; receptacle cream, 3-5 seeded.

Flowering \& fruiting: May-September.

Habitat: In evergreen and semi-evergreen forests, among pine woods at an elevation above $1500 \mathrm{~m}$, associated with Arisaema galeatum, A. speciosum and $A$. tortuosum.

Distribution: India, China, Bhutan and Nepal.

Specimens examined: INDIA, Aruanchal Pradesh, Lohit district, Hayuliang, along Dalai river, 14.01.1970, J. Joseph 48945 (ASSAM!). Upper Dibang Valley district, s.loc., 1700 m, 15.04.2001, M. Bhaumik 3817 (CAL!); Mayudia to Anini, 1865 m, 09.05.2015, Arunkumar \& Salim 144847 (CALI!); Roing-Mayudia, $1125 \mathrm{~m}$, 09.05.2015, Arunkumar \& Salim 144834 (CALI!). West Kameng district, Bomdila, Thungri Nalla, 13.10.2015, in fruiting, Arunkumar \& Salim 144941, 144942 (CALI!). Manipur, Senapati district, Kujeree Forest, Maram Side, 18.04.2006, A.A. Mao \& R. Gogoi 111178 (ASSAM!). Meghalaya, East Khasi Hills district, Cherrapunjee, Mowsmai
Cave, 1300 m, 10.05.2013, Manudev E Santhosh Nampy 135225 (CALI!); ibid., 22.07.2014, in fruiting, Manudev 139895 (CALI!); Mowmluh Cave, 4500 ft., 22.04.1943, N.L. Bor 187, 188 (BSD!); Shillong peak, $6000 \mathrm{ft}, 23.05 .1943$, N.L. Bor 17346 (BSD!). Nagaland, Kohima district, Dzuko Valley, 03.06.2005, A.A. Mao 109039, 109040 (ASSAM!). Sikkim, East Sikkim district, Baluwakhani, Gangtok, 1800 m, 25.04.1980, P. Chakrabarthy 135 (BSHC!); Chandmari, Nathula Road, Gangtok, 2100 m, 07.05.2014, Manudev 138870 (CAL!); Fambong la Rest House to Kawlakhola, 17.07.1992, S.K. Rai 20853 (BSHC!); Hanuman Tok, 07.05.2014, 2200 m, 138865, Manudev \& Syam Radh 138865 (CALI!); Meriang, way to Bhusuk Basty, 09.05.1984, S. Singh 2956 (BSHC!); Pangthang, near Spices Board, way to Mangan, 1900 m, 04.05.2014, Manudev \& Syam Radh 138848 (CALI!); near Pangthang, $1951 \mathrm{~m}$, 04.05.2014, Manudev \& Syam Radh 138857 (CALI!); Raj Bhavan Compound, Gangtok, 24.04.1984, D. Banerjee 2906 (BSHC!); ibid., 25.04.1980, P. Chakrabarthy 134 (BSHC!); Rangtang to Sangtang, 1800 m, 04.05.2014, Manudev \& Syam Radh 138854 (CALI!); Sangthang, near waterfall, way to Mangan, 1900 m, 04.05.2014, Manudev, Syam Radh \& Prashob 138850 (CALI!). North Sikkim district, Kabi Sacred groves, 11.06.1997, S.S. Dash \& S.K. Rai 17225 (BSHC!); ibid., 15.06.1999, S.S. Dash 20760 (BSHC!); Singhik towards Mangan, 24.04.1988, R. Seshagiri Rao 92 (ASSAM!). South Sikkim district, Sada, on the way, 11.05.1991, R.C. Srivastava 13188 (BSHC!); Tendong R.F., 07.06.2000, B.K. Shukla 23527 (BSHC!). West Sikkim district, Khecheopalri Lake surroundings, 11.05.1986., S.K. Rai 5420, 5421 (BSHC!); ibid., 1875 m, 14.05.1994, G.P. Sinha 16087 (BSHC!); ibid., 18.05.2002, D. Maity \& N. Pradhan 23469 (BSHC!); Varsey to Okhrey, 03.06.2004, S.K. Rai 14277 (BSHC!); Yuksom, 19.05.2002, D. Maity E N. Pradhan 23489, 23492 (BSHC!). Uttarakhand, Almora district, Dafia Dhura, 01.08.1972, C.M. Arora 49546 (BSD!). Chamoli district, Anusuya Devi temple, 1750-2000 m, s.d., B.D. Naithani 44036 (BSD!); Dewalikhal to Karanprayag, 24.06.1979, B.D. Naithani 68077 (BSD!); Kachula Khark, above Mandal, Chamoli, 26.06.1993, H.B. Naithani 1860 (BSD!). Pithoragarh district, Bogdiyar, on the way, 06.1986, Bipin Balodi 77549 (BSD!); Dhani Kholta, 12.09.1983, fruiting, Bipin 
Balodi 75042 (BSD!); Rungling forest, 2000-2800 $\mathrm{m}, 17.06 .1960$, T.A. Rao 11929 (BSD!). TehriGarhwal district, Gohna-Ramun, Garhwal, 2500m, 10.06.1959, M.A. Rau 10086 (BSD!); Govana, 1400 m, 29.05.1979, A.K. Goel 67727 (BSD!); Urni-Jhala, Tehri, 28.09.2000, fruiting, Uniyal \& Pundir 96983 (BSD!). Kumaon, 4000 m (12000ft.), Strachy 13 (CAL!). Uttar Pradesh, Sitapur district, Sitapur, 1600 m, 22.05.1972, B.D. Naithani 47928 (BSD!). West Bengal, Darjeeling district, Algarh, near Balwagani, way to Lava, $1761 \mathrm{~m}, 30.04 .2014$, Manudev138830 (CALI!); ibid., 1700 m, 30.04.2014, Manudev E Syam Radh 138825 (CALI!); Darjeeling, s.d., Talbot 3339 (BSI!); ibid., 1875, 7000 ft, J.S. Gamble 1276B, 1276D (BSD!); ibid., 05.1880, J.S. Gamble 8074 (BSD!); ibid., 05.1882, J.S. Gamble 10324 (BSD!); ibid., 10.05.1895, Talbot 3363 (BSI!); Jorebungalaw, $2 \mathrm{~km}$ towards Sonada, 26.04.2014, Manudev 138812 (CALI!); Lava, 02.06.13, Manudev 02061311(CALI!); way to Lava, 02.06.13, Manudev 02061302; Maneybhanjang to Sundekphu, 04.05.2015, Arunkumar 144806 (CALI!); Mirik, 1900 m, 30.04.2014, Manudev \& Syam Radh 138833 (CALI!); Rangiroom, near Forest Beat Office, $1650 \mathrm{~m}, 16.07 .2014$, in fruiting, Manudev \& Abdul Kabeer 139850 (CALI!); Rungiroom to Mungpoo, 1617 m, 16.07.2014, Manudev 139853 (CALI!); Rishap, near Lava, 2211 m, 30.04.2014, Manudev 138840 (CALI!).

Notes: This species is closely related to A. leschenaultii Blume in having greenish to purple spathe and stoloniferous tuber but can be differentiated by more slender spadix appendix with a rugose, subtruncate to sub-capitate tip. It was Schott (1859) who described this species along with $A$. affine Schott and $A$. alienatum Schott from the collections of Hooker from Sikkim. Both $A$. affine and $A$. alienatum were subsequently synonymised under this taxon by later workers (Hooker, 1893; Engler, 1920).

Typification: Schott (1859) described A. affine based on the collections of Hooker from Sikkim. There are two sheets at Kew (K000203007 and K000203008), both marked as type specimen by Schott. However, both of these sheets are part of different collections that are evident from the altitude shown in the field tickets. Since a proper type was not designated, the sheet no. K000203008 is chosen here as the lectotype conforming to the latest code, excluding the pistils at the left.

Schott (1859) described $A$. alientaum from the collections of Thompson from Garwhal and Griffith from Bhutan. There are two sheets collected by Griffith, one each at K (Griffith 2630, K000203003) and BM (Griffith 2629, BM000958547) and one sheet collected by Thompson from Garwhal at K (Thompson s.n., K000203002). The sheets at K were mentioned by Schott as the type and therefore a lectotype must be selected. The sheet by Griffith has a single plant mounted on it but with a deformed spathe and the sheet by Thompson has two plants with intact spathes. The sheet K000203002, has two specimens which is marked here as A and B. Among them, $\mathrm{A}$ is the best representative of the name and selected here as the lectotype.

Arisaema consanguineum Schott, Bonplandia 7: 27. 1859, Prodr. Syst. Aroid. 52. 1860; N.E.Br., J. Linn., Bot. 18: 242. 1880; Hook.f., Fl. Brit. India 6: 505. 1893; Engl. in Diels, Bot. Jahrb. Syst. (36)82: 11. 1905; Pamp., Boll. Soc. Bot. Ital. 9: 289. 1911; Craib, Bull. Misc. Inform. Kew 10: 397. 1912; Dunn \& Tutcher, Bull. Misc. Inform. Kew, Addit. Ser. 10: 288. 1912; Engl. in Diels, Notes Roy. Bot. Gard. Edinburgh 6: 276. 1912; Engl. et al. in Limpricht, Repert. Spec. Nov. Regni. Veg. 12:313. 1912; Hayata, Icon. Pl. Formosan. 5: 241. 1915; Engl., Pflanzenr. IV.23F(73): 175. 1920; Hand.Mazz., Symb. Sin. 7: 1365. 1936; Gagnep., Fl. IndoChine 6(9):1188. 1942; Chatterjee, Bull. Bot. Soc. Bengal 8: 122. 1955; H.Hara, Fl. E. Himalaya, Sec. Rep., Bull. 348. 1971; J.C.Wang, Bot. Bull. Acad. Sin. 37(1): 77. 1996; Gusman, Bull. Jard. Bot. Natl. Belg. 67: 221. 1999; Gusman \& L.Gusman, Gen. Arisaema, ed. 2. 371. 2006. A. erubescens (Wall.) Schott var. consanguineum (Schott) Engl. in A.DC. \& C.DC., Monogr. Phan. 2: 558. 1879. Lectotype (designated by Manudev \& Nampy, 2016): INDIA, Sikkim, s.d., J.D.Hooker s.n. (CAL0000001307!).

A. tatarinowii Schott, Bonplandia 7: 27. 1859, Prodr. Syst. Aroid. 53. 1860; Engl. in A.DC. \& C.DC., Monogr. Phan. 2: 559. 1879; Engl., Bot. Jahrb. Syst. 29: 236. 1901. Type: Not seen.

A. vituperatum Schott, Bonplandia 7: 28. 1859, Prodr. Syst. Aroid. 54. 1860. A. erubescens (Wall.) Schott var. vituperatum (Schott) Engl. in A.DC. \& C.DC., Monogr. Phan. 2: 558. 1879. Type: NEPAL, s.loc., s.d., Wallich Cat. No. 8915 
A. giraldii Baroni, Boll. Soc. Bot. Ital. 1893: 515. 1893. Type: Not seen.

A. davidianum Engl., Bot. Jahrb. Syst. 25: 27. 1898. A. consanguineum var. davidianum (Engl.) Engl., Pflanzenr., IV, 23F: 177. 1928. Type: Not seen.

A. tatarinowii Schott f. latisecta Engl., Bot. Jahrb. Syst. 29: 236. 1901. A. consanguineum Schott f. latisectum (Engl.) Engl., Pflanzenr., IV, 23 F: 176. 1920. Type: Not seen.

A. brevipes Engl., Bot. Jahrb. Syst. 36(82): 11. 1905. Type: Not seen.

A. consanguineum Schott var. giganteum Pamp., Bull. Soc. Tosc. Ortic. 16(7): 227. 1911. Type: Not seen.

A. consanguineum Schott f. alpestre K.Krause, Repert. Spec. Nov. Regni Veg. Beih. 12: 313. 1922. Type: CHINA, Sichuan, on top of Wan fu Ding, Limpricht (?)

A. undulatum K.Krause, Repert. Spec. Nov. Regni Veg. Beih. 12: 313. 1922. Type: Not seen

A. kerrii Gagnep., Notul. Syst. 9: 125. 1941, nom. illeg.

A. erubescens auct. Ma \& H.Li, Aroideana 40(3): 120. 2017. non Schott 1832.

Fig. 12

Deciduous, dioecious or very rarely monoecious, succulent, perennial herbs, c. $1 \mathrm{~m}$ tall. Subterranean stem a tuberous corm, globose to subglobose, 3-6 cm diam., 2-4 cm tall, cream-white; tuberlets often present in mature corms, a few, surrounding the pseudostem. Roots many, from the upper side of the corm, white. Cataphylls 2 or 3, obtuseorbicular at apex, mucronate; outer $c .2 \mathrm{~cm}$ long, pale to white; middle $5.5-12 \mathrm{~cm}$ long, pale to pink, pale to dark brown mottled; inner $9-20 \mathrm{~cm}$ long, pale green to brown, with faint or dark rosepink to brownish mottling. Leaves 1 or rarely 2, radiatisect, usually unfolds with the emergence of inflorescence; petiole $22-110 \mathrm{~cm}$ long, 0.3-1.5 $\mathrm{cm}$ thick, pale to dark green, not mottled; leaflets 9-21, sessile, narrow, linear to oblong, $7.5-23 \mathrm{~cm}$ long, 1.6-5.2 cm wide, long acuminate at apex and prolonged in to a greenish to brown tail, base gradually cuneate, margins entire, often wavy or undulate, pale-dark green ventrally, glaucous dorsally. Pseudostem 20-45 cm long, 1-2.5 cm thick, wrapped by cataphylls, mottled as in petiole. Inflorescence held below the leaves; peduncle
16-55 cm long, shorter than petiole, green, pale to dark brownish green or purple, exserted by 7-10 $\mathrm{cm}$ long from the pseudostem. Spathe $7-20 \mathrm{~cm}$ long with a long tail up to $25 \mathrm{~cm}$ long; tube of spathe cylindric, slightly funnel-shaped towards the mouth, 5-9 cm long, 2-3.5 cm wide, pale green to green or rarely purple stained, sometimes with faint inconspicuous lines along veins; margins of the mouth dilated to a revolute auricular extension; limb ovate, $6-10 \mathrm{~cm}$ long, $3.2-5.5 \mathrm{~cm}$ wide, wider than tube, acute-acuminate and prolonged in to a slender tail, 10-25 cm long, green all over, sometimes purple blotched, arched over and curved down. Female spadix sessile, $8-10.2 \mathrm{~cm}$ long, $0.4-0.8 \mathrm{~cm}$ thick; fertile region $2.7-3.7 \mathrm{~cm}$ long, followed by few neuters along c. $0.5 \mathrm{~cm}$; pistils many, sessile, compactly arranged, ovoid or bottle-shaped, green; ovules 4-6, white; style short; stigma papillate, stellate, sessile; neuters subulate, a few, 0.3-0.5 cm long, scattered, curved, green; appendix cylindric, decidedly stipitate with a slight constriction at the base after neuters, reaching the mouth of the tube or just exceeding, cylindric, rounded and smooth at apex, green to light green. Male spadix sessile, similar to female, slender, 5.5$6.2 \mathrm{~cm}$ long, $0.3-0.5 \mathrm{~cm}$ thick; fertile region $c$. $1.5-2 \mathrm{~cm}$ long, pale green to green; neuters usually absent; male flowers scattered over or crowded at the base and distant above, sessile or decidedly stipitate, 2-4-androus; anthers cream, dehisce by an apical round to oblong pore. Fruiting spike cylindric, 4-6 cm long, 2.5-4 cm wide, borne on a nodding peduncle; receptacle cream; berries ovoid compactly arranged, 4-6 seeded.

Flowering \& fruiting: April-June.

Habitat: In evergreen and semi-evergreen forests, grasslands, under pine woods at an elevation above $1300 \mathrm{~m}$, associated with A. concinnum and A. tortuousum.

Distribution: India, Bhutan, China, Nepal, Myanmar and Thailand.

Specimens examined: INDIA, Arunachal Pradesh, Lower Dibang Valey district, Athunli, $960 \mathrm{~m}$, 01.05.1998, M. Bhaumik 1518 (CAL!); West Kameng district, Dum, on the bank of river Dirang, fruiting plant, 24.09.1964, J. Joseph 40292 (ASSAM!). Manipur, Senapati district, Mao (Mao to Kegwing), c. 1830 m (6000 ft), 02.05.1882, 


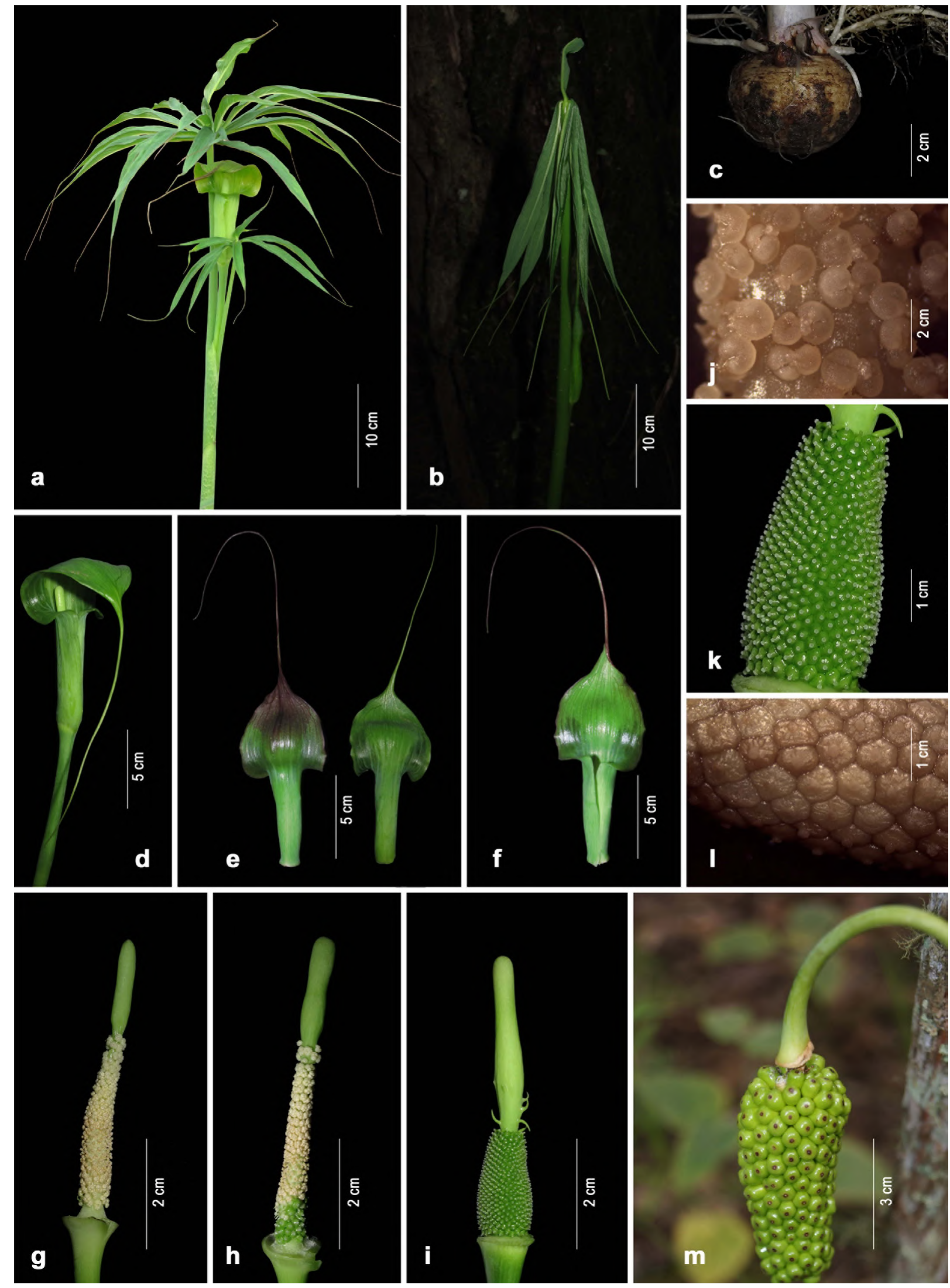

Figure 12. Arisaema consanguineum Schott: a. Habit; b. Leaf emergence; c. Corm; d. Inflorescence; e. Spathe-back view; f. Spathe-front view; g. Male spadix; h. Bisexual spadix; i. Female spadix; j. Stamens-enlarged view; k. Pistils; I. Pistils-enlarged view; m. Fruiting spike. 
G. Watt 6861 (CAL!). Meghalaya, East Khasia Hills district, Dumpep, 30.05.1911, I.H. Burkill E S.C. Banerjee 34249 (CAL!); ibid., 16.04.1969, A.S. Rao 47420 (ASSAM); ibid., c. 1920 m (6300 ft), 30.05.1911, I.H. Burkill \& S.C. Banerjee 34258 (CAL!); Jowai, 07.05.1961, D.B. Deb 24425 (ASSAM!); Laitlyngkot, fruiting plant, 16.07.1946, G.K. Deka 22262; Mawphalang, sacred forest, 31.05.1973, P.K. Hajra 51932 (ASSAM!, CAL!), 51933 (ASSAM!); Mukhla, near Jowai, 14.05.2013, Manudev \& Santhosh Nampy 135247 (CALI!); Mylliem towards north, 29.05.1911, I.H. Burkill \& S.C. Banerjee 104 (CAL!); Nongstoin, 10.05.2013, Alfred \& Manudev 135231 (CAL!); Nongstoin to Shillong, 10.05.2013, Alfred \& Manudev 135232 (CAL!); Sangpung-Raliang, on the way from Jowai to Barapani, 23.05.1965, A.S. Rao 42539 (ASSAM!, CAL!); Shillong, c. $1530 \mathrm{~m}$ (5000 ft), 01.06.1885, C.B. Clarke 38224 (CAL!); ibid., c. 1500 m (4900 ft), 26.05.1911, I.H. Burkill \& S.C. Banerjee 37 (CAL!): ibid., 27.05.1911, I.H. Burkill \& S.C. Banerjee 68 (CAL!); ibid., 29.05.1911, I.H. Burkill \& S.C. Banerjee 51 (CAL!); ibid., 05.1918, H.G. Carter 826, 840 (CAL!); Shillong, woodlands Camp (new colony), 04.06.1960, V.N. Naik 18181 (ASSAM!, CAL!); Shillong near Cantonement, 10.05.2013, Manudev \& Santhosh Nampy 135214; Shillong, BSI woodlands, fruiting plant, 02.08.1967, D.M. Verma 35667; Shillong Peak, 17.06.1967, D.M. Verma 35638 (ASSAM!); ibid., $1800 \mathrm{~m}, 17.06 .1956$, R.S. Rao 2741 (CAL!); Khasia hills, 06.1876, s.coll. 280 (CAL496077!); ibid., s.d., J.D. Hooker \& T. Thomson s.n. (CAL496093!); ibid., s.d., Griffith s.n. (CAL496091!). Nagaland, Mokokchung district, Mokokchung, Naga Hills, 05.1895, s.coll. 11696 (CAL!). Sikkim, North Sikkim District, Singhik, 14.05.1945, Dr. K. Biswas 6802 (CAL!); Chungthang, 15.05.1945, Dr. K. Biswas 6825 (CAL!). s.loc., s.d., R. Seshagiri Rao 342 (CAL!). Uttarakhand, Pithoragarh district, Pangu, Kumaon, 1800 m, 10.06.1960, T.A. Rao 11710 (CAL!). West Bengal, Darjeeling district, Darjeeling, c. 2130 m (7000 ft), 04.1882, J.S. Gamble 10327 (CAL!); Rangbee, 12.05.1877, Griffith 5975 (CAL!); ibid., 12.05.1877, J.L. Lister s.n. (CAL496067!); Senchal, 05.1878, G. King s.n. (CAL!); Senchal WLS, 26.05.2007, A.K. Ghosh 41623A (CAL!); Batasia to Palmajura, 08.05.1956, D. Chatterjee 44 (CAL!).

Notes: This species is close to $A$. fraternum but can be easily identified by its linear-oblong leaflets with a long tailed apex and spathe with an acuminate tip extending in a long tail as opposed to oblong-lanceolate leaflets without a tail at apex, and strongly drooping spathe limb without a tail.

Arisaema echinatum (Wall.) Schott in Schott \& Endl., Melet. Bot. 17. 1832; Blume, Rumphia 1: 94. 1836; Kunth, Enum. Pl. 3: 16. 1841; Schott, Syn. Aroid. 1: 30. 1856; Prodr. Syst. Aroid. 49. 1960; Engl. in A.DC. \& C.DC., Monogr. Phan. 2: 555. 1879; Hook.f., Fl. Brit. India 6: 596. 1893; Engl., Pflanzenr. IV.23F(73): 181. 1920; Hand.Mazz., Symb. Sin. 7: 1361. 1936; Chatterjee, Bull. Bot. Soc. Bengal 8: 124. 1955; H.Hara, Fl. East. Himalaya, Sec. Rep. 351. 1971; U.C.Pradhan, Himal. Cobra Lilies 90. 1990; Hajra \& D.M.Verma, Fl. Sikkim Monocot. 1: 188. 1996; Sasikala \& Vajravelu, J. Bombay Nat. Hist. Soc. 98(3): 495. 2001; Gusman \& L.Gusman, Gen. Arisaema, ed. 2. 374. 2006. Arum echinatum Wall., Pl. Asiat. Rar. 2: 30. t. 136. 1831. Lectoype (Step I. designated by Chatterjee 1955: 124; Step II. designated by Manudev \& Nampy, 2017): NEPAL, Sheopore?, June 1821, Wallich 8916 (K001131834, excluding the Arisaema species at lower right corner and the Typhonium plant at the base; iso K000203000, K000950293, K001131831 excluding plants of Arisaema erubescens (Wall.) Mart. and A. exile Schott). Epitype (designated by Manudev \& Nampy, 2017): Icone of Arum echinatum Wall. (Pl. Asiat. Rar. 2: t. 136. 1831)

Fig. 13

Deciduous, dioecious, perennial herbs, c. $70 \mathrm{~cm}$ tall. Subterranean stem a tuberous corm, globose, 4-7 cm diam., 2-4.5 cm tall, proliferating. Roots many, from the upperside of the corm, branched. Cataphylls 3, obtuse at apex, green or red. Leaves 1, rarely 2, radiatisect, emerges with the inflorescence; petioles $15-60 \mathrm{~cm}$ long, light green or purple, elongates after the spathe unfolds; leaflets 7-11, subsessile, broadly ovate, base cuneate, margins slightly serrate and undulate, apex mucronate, green above, glaucous beneath. Sheathing pseudostem $c$. $10 \mathrm{~cm}$ long, green, wrapped by cataphylls, mottled as in petiole. Inflorescence held near the ground level; peduncle much shorter than the petiole, 5-10 $\mathrm{cm}$ long, green; spathe $c .27 \mathrm{~cm}$ long including the apical tail; tube of the spathe cylindric, slightly funnel-shaped towards mouth, 3-5 cm long, 2-2.5 $\mathrm{cm}$ wide, outside green or purple with white stripes along the veins, inside with purple dotted stripes, 


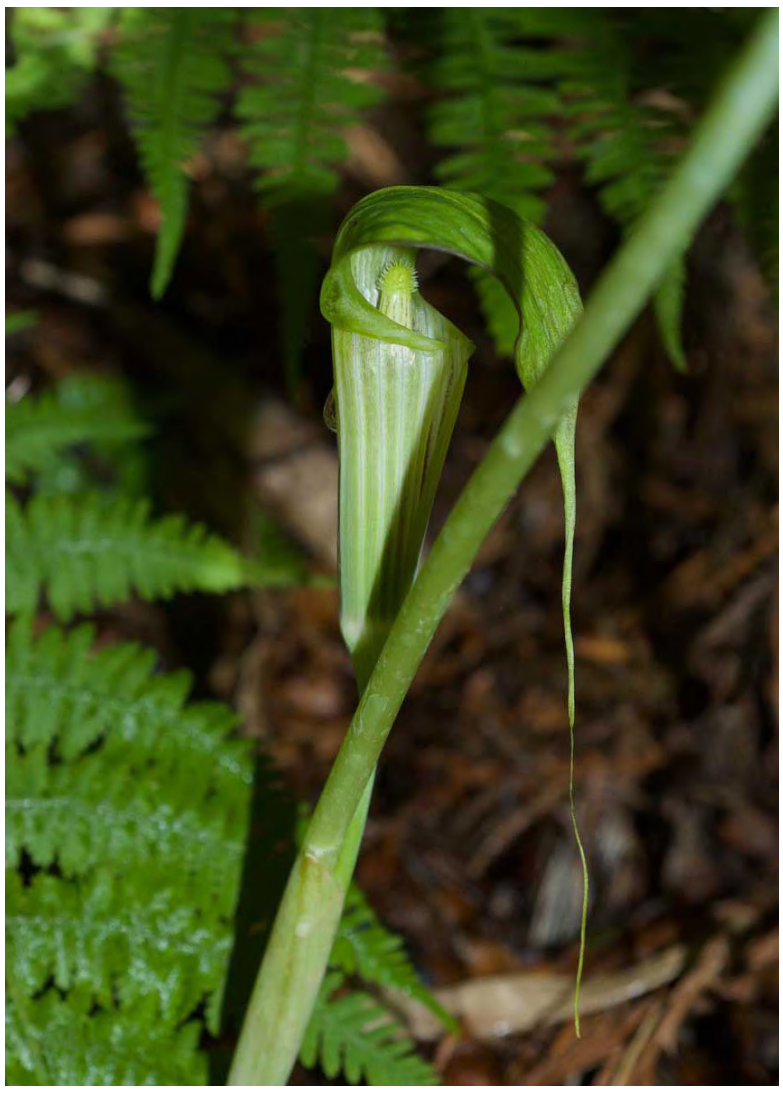

Figure 13. Arisaema echinatum (Wall.) Schott: a. Habit (Image, Guy Gusman, Belgium).

constricted near the mouth; margins recurved; spathe limb lanceolate-ovate, $3-7 \mathrm{~cm}$ long, 3-5 cm wide, bright green outside, carmine inside, margins carmine, acuminate at apex, prolonged in to a long tail, tail $5-15 \mathrm{~cm}$ long, green or carmine. Female spadix 4-5 cm long, $0.4-0.6 \mathrm{~cm}$ thick, cylindrical, slightly exserted from the tube; fertile region 1-2 cm long; pistils compactly arranged, ovoid, angular, green; style short; stigma cream; neuters absent; appendix cylindrical, 3-4 cm long, 0.4-0.6 $\mathrm{cm}$ thick, stipitate, stipe $c .0 .7 \mathrm{~cm}$ long, white with purple dotted, longitudinal lines, rugose and pale green or purple distally, apex orbicular, covered with thin, white and short prickly hairs; Male spadix slender, similar to female; male flowers scattered, stipitate, 3-4-androus; anthers purple, dehisce by a rounded or oblong pore, pollens white. Fruiting spike cylindrical, $5-5.5 \mathrm{~cm}$ long, $2.5-3 \mathrm{~cm}$ wide, borne on an upright peduncle; berries vermilion red, flat and lobulate at apex, 3-seeded.

Flowering \& fruiting: May-October.

Habitat: In forests, among Rhododendrons, above $2400 \mathrm{~m}$.
Distribution: India, Bhutan, China and Nepal.

Specimens examined: INDIA, Sikkim, North Sikkim district, Lachen, 3000 m, 07.06.1999, D. Maity 21328 (BSHC!); Tallom surroundings, 25.07.1986, DCS Raju \& S. Singh 6214 (BSHC!); Zemu Valley, c. 2438 m (8000 ft.), 09.07.1909, Smith \& Cave 1011 (CAL!).

Notes: This species is near to A. echinoides, a Chinese species, from which it can be distinguished by a stoloniferous subterranean stem and spathe limbs dark carmine inside with a few greenish white veins, anastomosing near the margin.

Arisaema fischeri Manudev \& Nampy, sp. nov.

Closely allied to Arisaema barnesi C.E.C.Fisch., from which it can be distinguished by cylindrical and smooth spadix appendix with a curved apex as opposed to a narrowly fusiform appendix, widest in the middle, tapering to a short tail with a small minutely warted apical knob and a ridged basal portion in the latter.

Type: INDIA, Kerala, Thiruvananthapuram district, Agasthyamala Biosphere reserve, Athirumala to Pongalappara, in flowering, 05.06.2014, Manudev \& Arunkumar 138933 (holo CALI!, iso MH!) Fig.14

Deciduous, dioecious, perennial herbs, c. $1 \mathrm{~m}$ tall. Subterranean stem a tuberous corm, globose to depressed globose, $2.5-6.5 \mathrm{~cm}$ diam., $1.5-4.5 \mathrm{~cm}$ tall, greenish-yellowish inside, producing elongate cormlets upon maturity. Roots many, arising from the upper side of corm. Cataphylls 3, rarely 4, purplish to brownish green or pale white, sometimes purple mottled, acute to obtuse at apex, wrapping the pseudostem; outer $2-4 \mathrm{~cm}$ long, usually pale white, or brownish green towards apex; middle 4.5-14 cm long; innermost dark coloured, 16-37 $\mathrm{cm}$ long, sometimes an outer fourth cataphyll $c$. 1-2 cm present. Leaf single, rarely 2, radiatisect, unfolding with the inflorescence; petioles 43-101 cm long, 0.5-1.6 cm thick, purplish to brownish green or pale green to whitish green, often mottled with purple or brown, sometimes glaucous; leaflets 7-9, petiolulate, elliptic to oblong-obovate, 15$31 \mathrm{~cm}$ long, 3.5-8.5 cm wide, cuneate at base, gradually tapering or narrowly acuminate at apex, margins slightly undulate, dark green above, pale beneath, sometimes glaucous. Pseudostem 21-62 $\mathrm{cm}$ long, 1-3.5 cm thick, coloured as in petiole. 

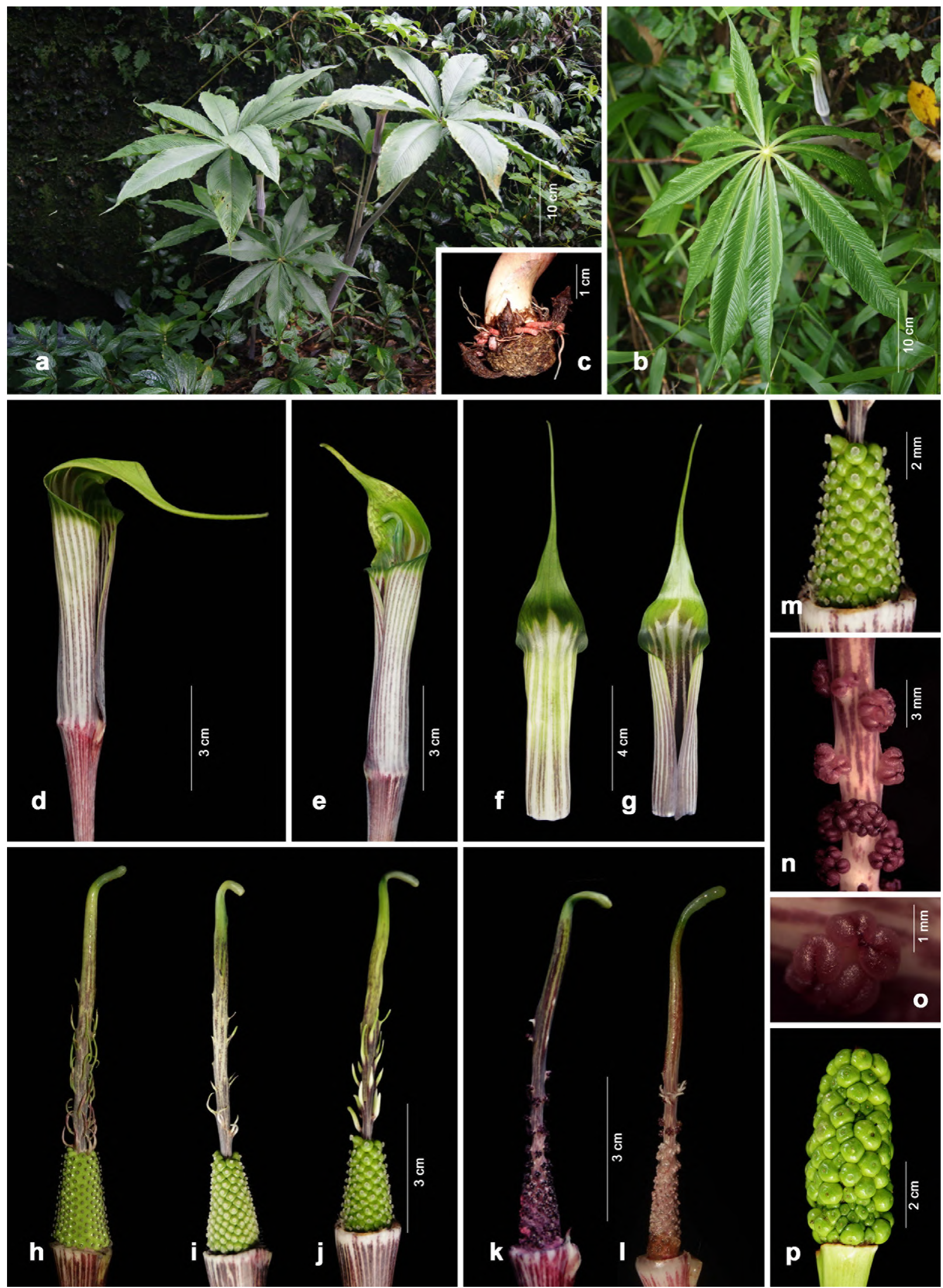

Figure 14. Arisaema fischeri Manudev \& Nampy sp. nov. a \& b. Habit; c. Corm; d \& e. Inflorescences; f. Spathe-front view; g. Spathe-back view; $\mathbf{h}$-j. Female spadices; k \& I. Male spadices; $\mathbf{m}$. Female floriferous region; $\mathbf{n}$. Male floriferous region; $\mathbf{0}$. Male flowers; $\mathbf{p}$. Fruiting spike. 
Inflorescence held below the leaf; peduncle 37$88.5 \mathrm{~cm}$ long, 0.4-1.4 thick, pale-brownish green, faintly mottled, exserted by $12-40 \mathrm{~cm}$ long from the sheathing pseudostem. Spathe 13-17 cm long; tube of spathe cylindric, funnel-shaped towards the mouth, 6-9.5 cm long, $1.2-2.2 \mathrm{~cm}$ wide, purple-greenish outside, dark purple inside, white striped along the veins; mouth margins straight or slighty recurved; spathe limb ovate, $4-9.5 \mathrm{~cm}$ long, 3-3.5 cm wide, usually shorter than the tube, gradually tapering in to a tail c. $3-5 \mathrm{~cm}$ long at the apex, green or yellowish-green, white striped at the base, turns yellow after anthesis, erect or horizontal, sometimes arching forward. Female spadix 9-13 cm long, cylindric, sessile; female floriferous region conical, 2-3.5 cm long, 0.7-1.3 $\mathrm{cm}$ wide; pistils compactly arranged, green; style absent; stigma papilose, white; ovules 2-5; neuters subulate, $0.5-0.8 \mathrm{~cm}$ long, upcurved, scattered along 3-4.5 cm along the base of appendix, purplish to green; appendix sessile, cylindric or terete, gradually tapering to a blunt, curved apex, purplish basally, green distally, exserted from the tube. Male spadix similar to female, slender, 7-7.5 cm long; floriferous region conical below, cylindric above; male flowers sessile, densely arranged below and scattered above, 2-6-androus; anthers reniform, purple, sessile, dehisce through an apical oblong pore; neuters usually absent, rarely very few, subulate. Fruiting spike cylindrical, c. $6 \mathrm{~cm}$ long, 2-3 cm wide, borne on an erect peduncle; receptacle cream; berries obovoid, 2-5-seeded.

Flowering \& fruiting: May-October.

Habitat: In evergreen forests, shola margins and under bamboo reeds, in humus rich soil and rock crevices. A total of 65 plants in flowering were observed in 2014, along the trek path from Athirumala to Pongalappara at an elevation above $1200 \mathrm{~m}$, in association with $A$. tortuosum and $A$. leschenaultii.

Distribution: India (southern Western Ghats), endemic.

Etymology: This taxon is named after Cecil Ernest Claude Fischer (1874-1950), British Botanist who described several species of Arisaema from southern India and completed Flora of Presidency of Madras after the demise of J.S. Gamble.

Specimens examined: INDIA, Kerala,
Thiruvananthapuram district, Agasthyamala Biosphere reserve, Athirumala to Pongalappara, in flowering, 11.06.2011, Manudev \& Santhosh Nampy 4448 (CALI!).

Notes: This species is also close to $A$. attenuatum in having a sessile and cylindric spadix appendix. However, the latter can be distinguished by a short triangular spathe limb with large roundish white patch at the base with radiating stellate arms.

Arisaema fraternum Schott, Bonplandia (Hannover) 7: 26. 1859; Prodr. Syst. Aroid. 45. 1860; Hook.f., Fl. Brit. India 6: 507. 1893; Engl., Pflanzenr. IV.23F(73): 178. 1920; Chatterjee, Bull. Bot. Soc. Bengal 8: 118. 1955; A.S.Rao \& D.M.Verma, Bull. Bot. Surv. India 18: 17. 1976 (1979); Gusman \& L.Gusman, Gen. Arisaema ed. 2. 387. 2006. Lectoype (designated here): INDIA, Meghalaya, Khasia Hills, s.d., Griffith 11 (K000400615 digital image!).

A. leschenaultii auct. Engl. in A.DC. \& C.DC., Monogr. Phan. 2: 552. 1879, non Blume 1836, pro parte.

Figs. $15 \& 16$

Deciduous, dioecious, succulent, perennial herbs, up to $56 \mathrm{~cm}$ tall. Subterranean stem a tuberous corm, depressed globose to subglobose, $2-4.5 \mathrm{~cm}$ diam., 2-2.8 cm tall, cream-white, stoloniferous. Roots many, from the upper side of the corm, white to pink. Cataphylls 2 or 3, obtuse-orbicular at apex, mucronate; outer $c .2 \mathrm{~cm}$ long, pale to white; middle 5.5-12 cm long, pale green to brownish green, pale rose to dark brown mottled; inner 9-21 $\mathrm{cm}$ long, enclosing the pseudostem, pale green to greenish brown, with faint or dark rose-purple to brownish mottling. Leaf solitary, radiatisect, usually unfolds completely after the emergence of inflorescence; petiole $27.5-133 \mathrm{~cm}$ long, 0.3-1.5 $\mathrm{cm}$ thick, dark green, purplish to brownish green, often mottled; leaflets 7-11, sessile, elliptic to lanceolate or oblong-lanceolate, $7.5-23 \mathrm{~cm}$ long, 1.6-5.2 cm wide, acute at apex, base cuneate, margins entire, often wavy or undulate, dark green ventrally, glaucous dorsally. Pseudostem 9-30 $\mathrm{cm}$ long, 1-2.5 cm thick, wrapped by cataphylls, mottled as in petiole. Inflorescence matures after the emergence of leaf, held below or at the level of leaf; peduncle 16-42 cm long, green, pale to dark brownish green or purple mottled, exserted by $7-12 \mathrm{~cm}$ long from the pseudostem. Spathe 


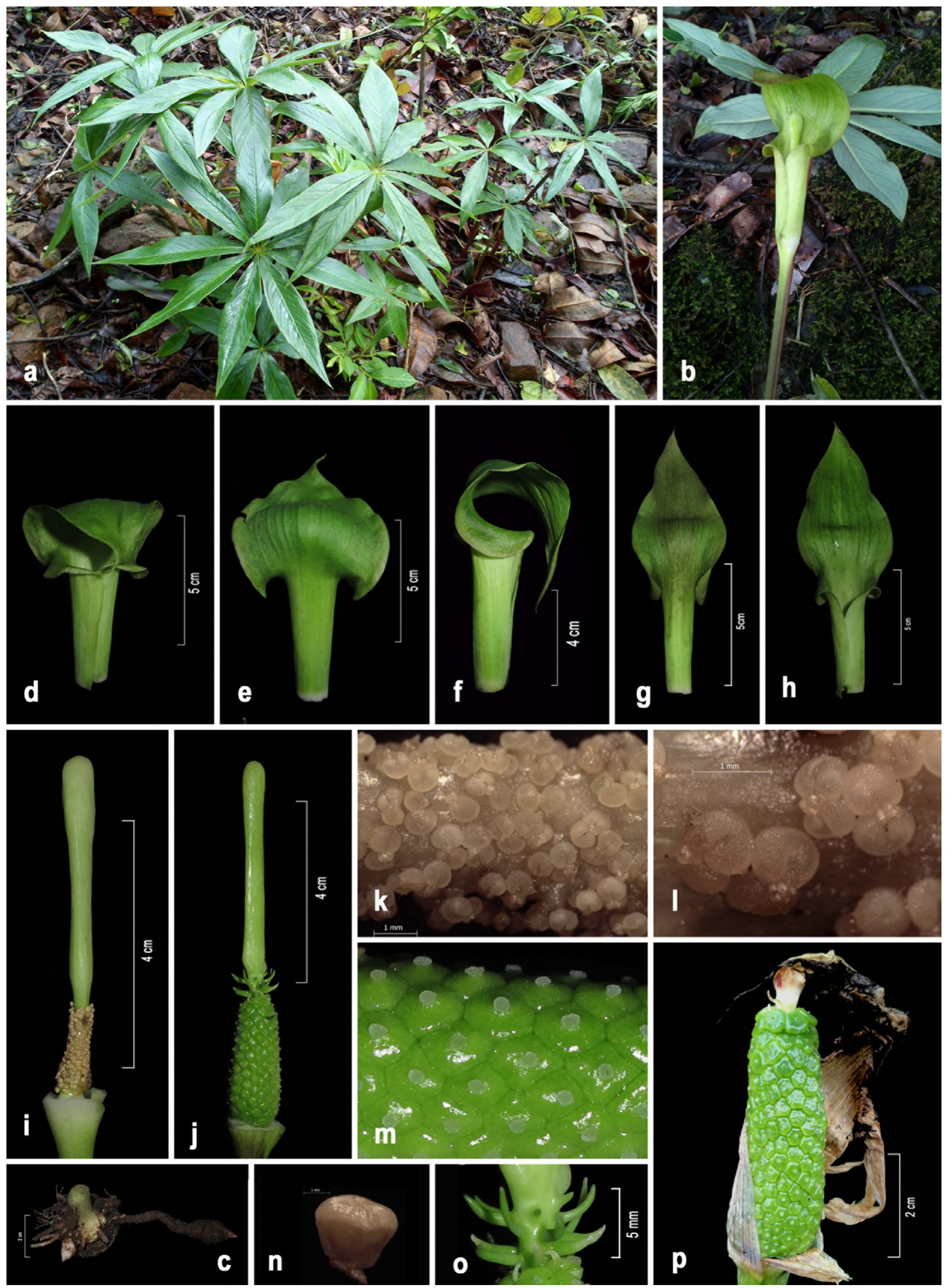

Figure 15. Arisaema fraternum Schott.: a \& b. Habit; c. Corm; d-h. Spathes (d \& h. front view; e \& g. back view; f. Side view); j. Male spadix; k. Female spadix; I. Male floriferous region; m. Male flowers-enlarged view; n. Female flowers-enlarged view; o. Neuters; $\mathbf{p}$. Pistil; q. Fruiting spike. 


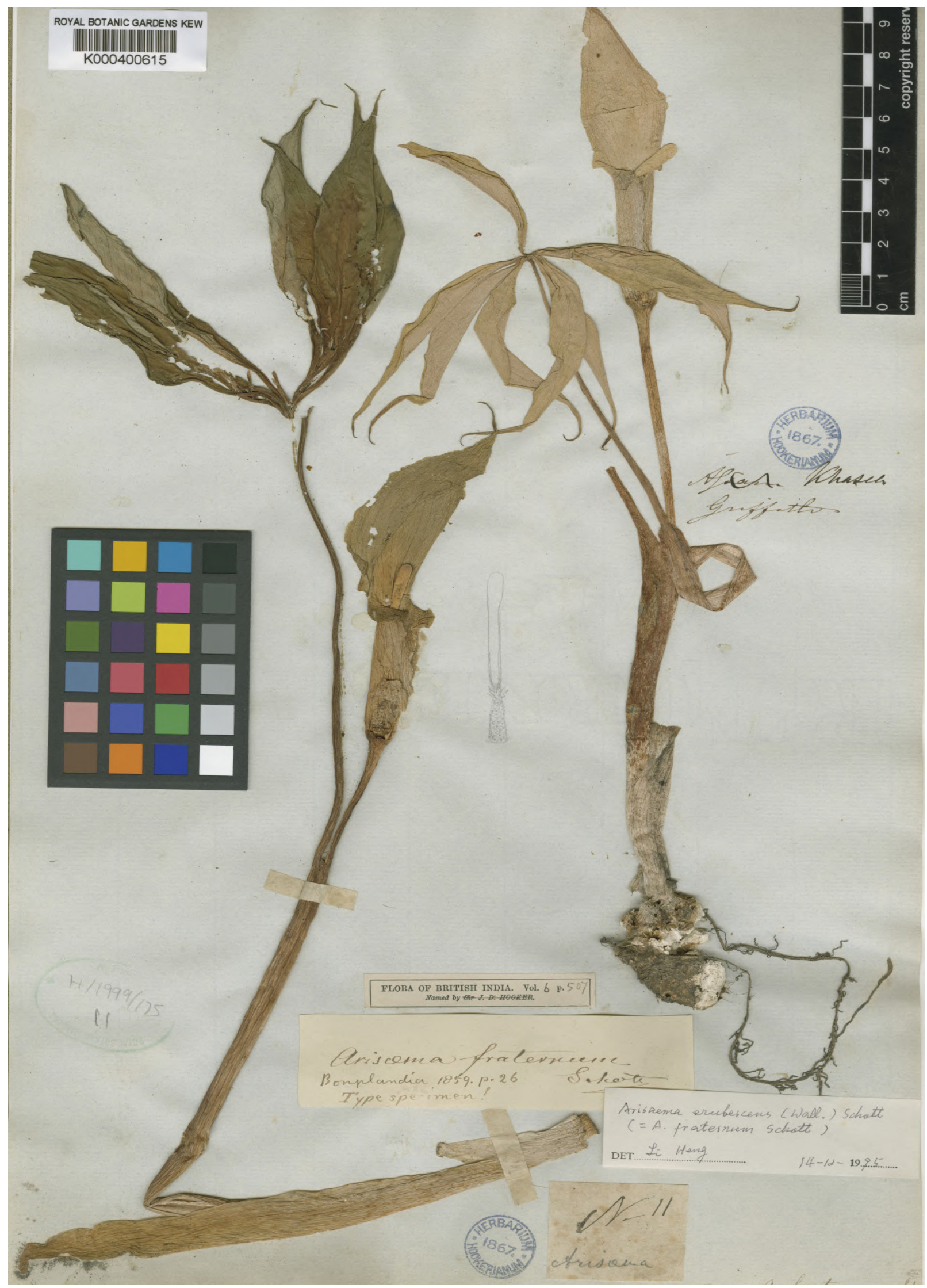

Figure 16. Lectotype of Arisaema fraternum Schott [Griffith s.n. (K000400615)] @) The Board of Trustees of the Royal Botanic Gardens, Kew. 
7-16 cm long; tube of spathe cylindric, slightly funnel-shaped towards the mouth, 3.5-4 cm long, 1-2 cm wide, pale green to green, sometimes with faint inconspicuous lines along veins; margins of the mouth dilated to a revolute auricular extension, $0.7-1.5 \mathrm{~cm}$ wide; limb ovate, oblong-ovate, widely ovate or ovate-lanceolate, $6-9.5 \mathrm{~cm}$ long, 3.2-6.2 $\mathrm{cm}$ wide, acute-acuminate, green all over, arched over and strongly curved down. Female spadix sessile, $8-10.2 \mathrm{~cm}$ long, $0.4-0.8 \mathrm{~cm}$ thick, reaching the mouth of the tube or just exceeding; fertile region $2.7-3.7 \mathrm{~cm}$ long, followed by few neuters along c. $0.5 \mathrm{~cm}$; pistils many, sessile, compactly arranged, rhomboid, 5 or 6-angled owing to its compact arrangement, green; ovules 4-6, white; stigma papillate, stellate, sessile; appendix cylindric, decidedly stipitate with a slight constriction at the base after neuters, blunt at apex, sometimes decidedly flattened, green to light green; neuters subulate, a few, $0.3-0.5 \mathrm{~cm}$ long, scattered, upcurved, green. Male spadix sessile, similar to female, slender, 5.5-6.2 cm long, 0.3-0.5 cm thick; male fertile region $1.5-2 \mathrm{~cm}$ long, pale green to green; male flowers scattered over or crowded at the base and distant above, sessile or decidedly stipitate, 1 or 2-androus; anthers cream, dehisce by an apical oblong pore; neuters absent. Fruiting spike cylindrical, c. $5 \mathrm{~cm}$ long, c. $2.5 \mathrm{~cm}$ wide, borne on an upright peduncle; berries compactly arranged, rhomboid, 5 or 6-angled, green when young, turns red upon maturity, 5-6-seeded.

Flowering \& fruiting: April-June.

Habitat: In evergreen and semi-evergreen forests, near grasslands, riverbanks at an elevation above $1300 \mathrm{~m}$, associated with A. album, A. concinnum and A. tortuousum.

Distribution: India (North-East India), endemic.

Specimens examined: INDIA, Meghalaya, Khasia \& Jaintia hills district, Cherrapunjee, 10.05.1940, G.K. Deka 22309 (ASSAM!); Mowsmai, near cave, plant, 10.05.2013, Manudev \& Santhosh Nampy 135226 (CALI!). Pyrunusula, 29.04.1940, R.N. Dr. 21864 (ASSAM!); Tissy Jarwa, way to Nongthymmai, Cherrapunjee, 10.05.2013, Manudev 135219 (CALI!); Nongthymmai, on river banks, 10.05.2013, Manudev \& Santhosh Nampy 135222 (CALI!); Nohsngithiang, Forest patch before Seven Sister Falls, 10.05.2013, Manudev \&

\section{Santhosh Nampy 135229 (CALI!).}

Notes: It is close to A. consanguineum, but can be easily differentiated by its oblong-lanceolate leaflets, glaucous on the ventral side, and completely green, ovate-widely ovate, acute and strongly drooping spathe limb as opposed to linear, long caudate leaflets without a glaucous base and green-purple, ovate-lanceolate, long caudate spathe limb.

Typification: Schott (1859) while describing $A$. fraternum cited Khasia hills in Meghalaya as the locality but without mentioning the collector. Subsequently, in his Prodromus Systematis Aroidearum (1860), he gave the details of collector as "Khasia-Griffith- v.s in Herb. Hooker" indicating that he based his descriptions on collections of Griffith from Khasia that are deposited in Hooker's herbarium (now K). There are two sheets by Griffith at K (K000400614 \& K000400615). The specimen K000400614 was collected from Cherrapunjee and the date of collection is written March 1831 on the field ticket appended. There is a Kew distribution label attached to the right side of the sheet indicating the name of the collector as Griffith with the field number as 5978. The other sheet (K000400615) does not have a Kew distribution label but has a field ticket attached to the lower part of the sheet with a number (No.11). There is no indication of the date of collection and locality except for an annotation "Assam, Griffith" and the locality is corrected later as Khasia, striking off 'Assam'. So technically these two sheets serve as the syntypes of this species. Hence, K000400615 with a determination slip attached by Schott on this sheet indicating it as the type specimen, is selected here as the lectotype.

Arisaema leschenaultii Blume, Rumphia 1: 93. 1836; Kunth, Enum. Plant. 3: 16. 1841; Schott, Prodr. Syst. Aroid. 51. 1860; Engl. in A.DC. \& C.DC., Monogr. Phan. 2: 552. 1879, excl. syn. A. fraternum Schott; Hook.f., Fl. Brit. Ind. 6: 507. 1894; Hook.f. in Trimen, Handb. Fl. Ceylon 4: 352. 1898; Woodrow, J. Bombay Nat. Hist. Soc. 13(3): 427. 1901; T.Cooke, Fl. Bombay 1: 821. 1903; Fyson, Fl. Nilgiri Pulney Hill-tops 1: 426, t. 271. 1915; Engl., Pflanzenr. IV.23F(73): 162. 1920; C.E.C.Fisch. in Gamble, Fl. Madras 3: 1585. 1931; Blatt. \& McCann, J. Bombay Nat. Hist. Soc. 35: 19. 1931; Chatterjee, Bull. Bot. Soc. Bengal 8: 127. 1955; K.M.Matthew, Ill. Fl. Tamil Nadu Carnat. 
t. 765. 1982; Sivad. \& Nicolson in K.M.Matthew, Fl. Tamil Nadu Carnat. 3(2): 1688. 1983; P.V.Bole \& M.R.Almeida, J. Bombay Nat. Hist. Soc. 83(3): 596. 1986; Manilal, Fl. Silent Valley 332. 1988; Nicolson in Dassan. \& Fosberg, Rev. Handb. Fl. Ceylon 6: 71. 1988; K.M.Matthew, Fl. Palni Hills 1369. 1999; Sivad. in Manoharan et al., Silent Valley-Whispers of Reason. 235, figs. 9, 10. 1999; N.Mohanan \& Sivad. Fl. Agasthyamala 756. 2002; Gusman \& L.Gusman, Arisaema ed. 2. 392. 2006, pro parte. Lectotype (Step I. designated by Nicolson, 1988: 71; Step II. designated by Manudev \& Nampy, 2017): INDIA, Tamil Nadu, Nilgiris (as Nelligerry), s.d., Leschenault 69 (P00390539 digital image!; isolectotype P00390538 digital image!)

A. huegelli Schott, Syn. Aroid. 27. 1856. Type: Not seen.

A. papillosum Steud. ex Schott, Syn. Aroid., 31. 1856, Prodr. Syst. Aroid. 46. 1860; Thwaites, Enum. Pl. Zeyl. 335. 1864; Hook., Bot. Mag. 91: t. 5496. Lectoype (designated here): INDIA, Tamil Nadu, Nilgiris (in montibus Nilagiri), Althikarhattii, June, Hohenacker 1300 (P1750545 digital image!).

A.pulchrum N.E.Br., J. Linn. Soc. Bot. 18:252.1881; Hook.f., Fl. Brit. India 6: 505. 1894; C.E.C.Fisch. in Gamble, Fl. Pres. Madras 3: 1585. 1931. Type: INDIA, Sispara Ghats, West Nilgiris (sent by R.H. Beddome, cultivated in Kew), 03.1878, W. Bull s.n. (K000499493 digital image!)

Figs. $17 \& 18$

Deciduous, dioecious, succulent, perennial herbs, c. $62 \mathrm{~cm}$ tall. Subterranean stem a tuberous corm, depressed globose to subglobose, 2-7 cm diam., 1-5 cm tall, wrinkled, cream-white, tuberlets often present in mature corms, a few, surrounding the pseudostem, often stoloniferous. Roots many, from the upper side of the corm. Cataphylls 3 or 4 , acute or obtuse-orbicular at apex, mucronate; outer $c$. 1-4.5 cm long, pale to white often blushed with rose; middle 5.5-12 cm long, pale white-green or purple, pale rose to greenish brown mottled; inner 14.5-44 cm long, enclosing the pseudostem, pale green to greenish brown, with faint or dark rose, purple to brownish mottling, sometimes cylindrical below; often an outer pale-hyaline cataphyll c. 1-3 cm long can be seen. Leaf solitary, rarely 2, radiatisect, usually unfolds completely after the emergence of inflorescence; petiole 35-
$90 \mathrm{~cm}$ long, $0.5-1.3 \mathrm{~cm}$ thick, light green to dark brownish green, pale-brown to purplish-brown mottled; leaflets 6-11, sessile, elliptic-obovate or oblanceolate, 9-30 cm long, 3-10 cm wide, cuneate at base, acute-acuminate, margins entire, often wavy or undulate, dark green ventrally, pale dorsally. Pseudostem 17-54 cm long, 1-2 $\mathrm{cm}$ thick, wrapped by cataphylls, mottled as in petiole. Inflorescence held below the leaves; peduncle 29-69 cm long, light green, pale to dark brown or purple mottled, always greenish distally, sometimes green all over without any mottling, exserted by $10-25 \mathrm{~cm}$ long from the pseudostem. Spathe 11-20 cm long; tube of spathe cylindrical, slightly funnel-shaped towards the mouth, $5-8 \mathrm{~cm}$ long, 1.5-2 cm thick, greenish white, pale greengreen, greenish brown or pale purple with whitepale stripes along the veins; margins of the mouth slightly dilated to a revolute-auricular extension; limb ovate-lanceolate, 6.5-14 cm long, 3-6 wide, acute-acuminate, light to dark green, purplish or greenish brown all over with white to pale stripes along the veins, arched over and drooping. Female spadix sessile, $7-10.5 \mathrm{~cm}$ long, $0.4-0.8 \mathrm{~cm}$ thick; fertile region 2-3 long, followed by few neuters; pistils many, sessile, compactly arranged, globose, green; ovules 3-5, white; stigma papillate, stellate, sessile-subsessile, often with a dark blue neck; neuters subulate, few, 0.5-1 cm long, scattered, upcurved, green, sometimes bulbous based; appendix cylindrical, decidedly stipitate with a slight constriction at the base after neuters, reaching the mouth of the tube or just exceeding, cylindric and gradually tapering with a blunt apex, sometimes flattened, green to light green. Male spadix sessile, similar to female, slender, $5-8 \mathrm{~cm}$ long, $0.3-0.5 \mathrm{~cm}$ thick; fertile region $2-2.5 \mathrm{~cm}$ long; male flowers scattered over or crowded at the base and distant above, sessile or decidedly stipitate, 3-4-androus; anthers sessile, purple, dehisce by an apical pore; neuters very few or usually absent, subulate, 1-2 cm long, pale green. Fruiting spike cylindrical, c. $8 \mathrm{~cm}$ long, 4-5 cm wide; borne on an upright peduncle; berries globose, compactly arranged, green, 3-5-seeded.

\section{Flowering \& fruiting: April-October.}

Habitat: In evergreen and semi-evergreen forests, near grasslands and shola forests at an elevation above $1000 \mathrm{~m}$, associated with $A$. attenuatum, $A$. 

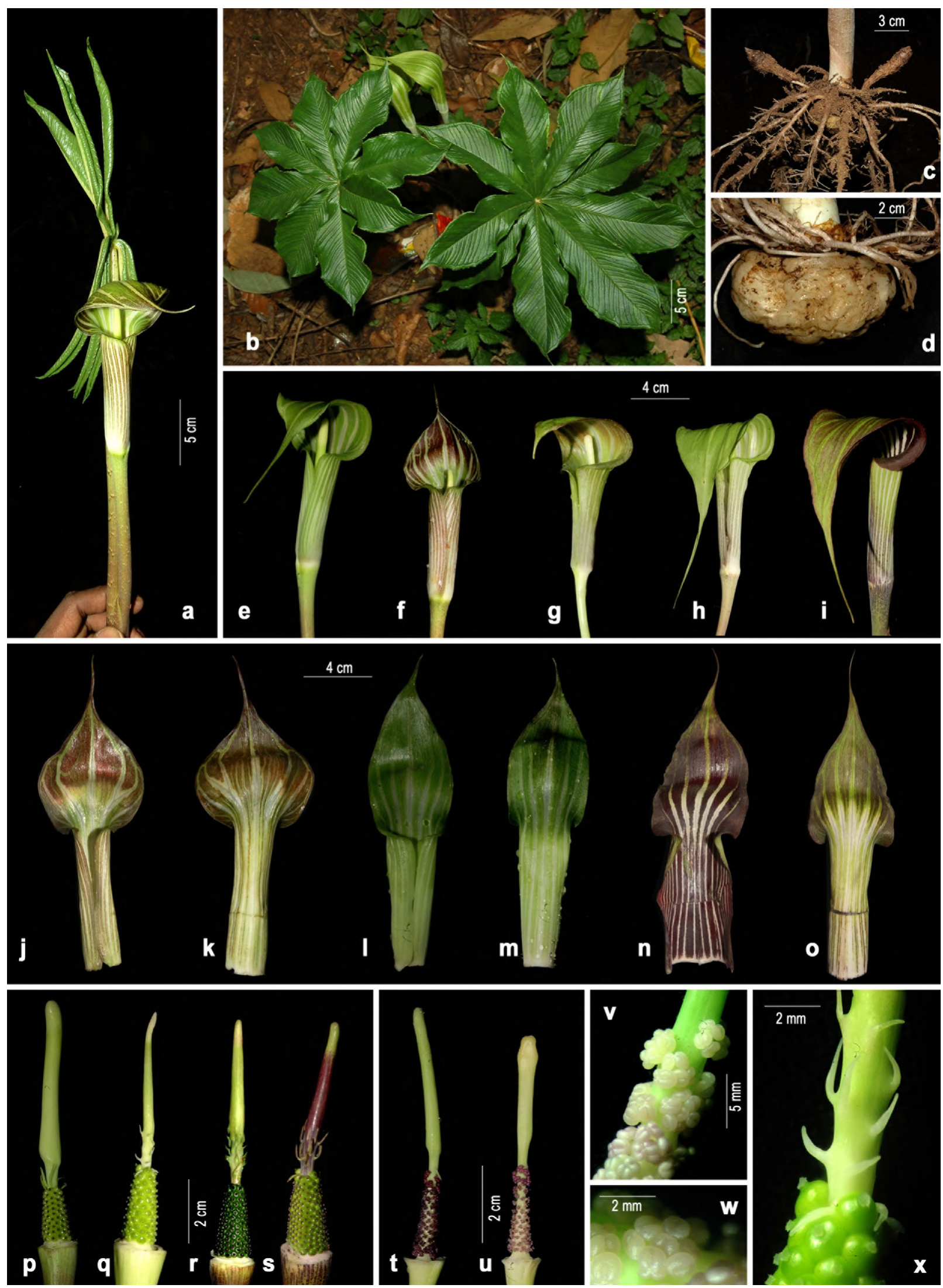

Figure 17. Arisaema leschenaultii Blume: a \& b. Habit; c \& d. Corm; e-i. Inflorescences; j-0. Spathe (j, l, n. front view; k, m, 0. back view); p-s. Female spadix; t \& u. Male spadix; v. Male floriferous region; w. Male flowers-enlarged view; $\mathbf{x}$. Female flowers and neuters. 


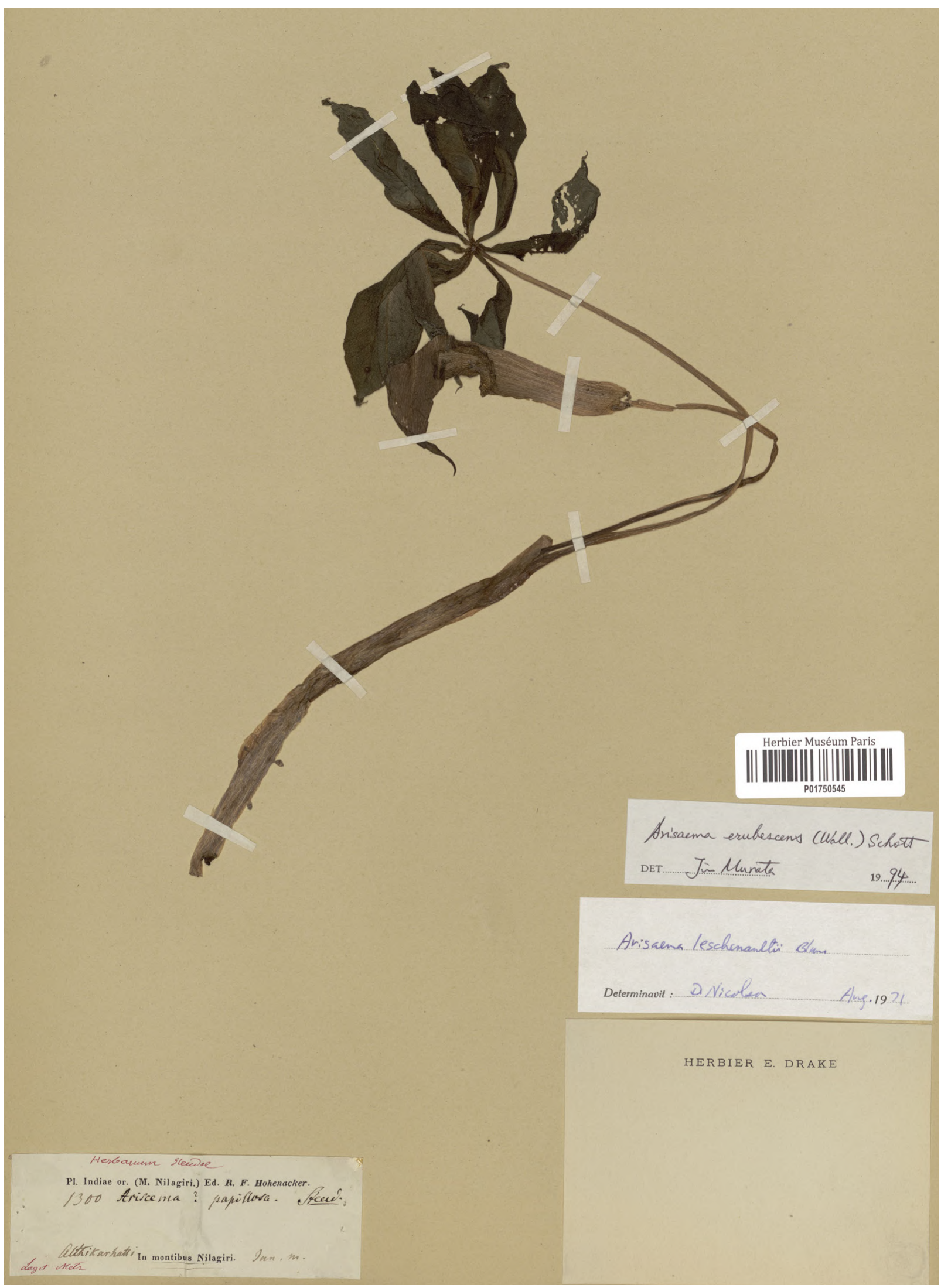

Figure 18. Lectotype of Arisaema papillosum Steud. ex Schott [Hohenacker 1300 (P1750545)] @ Muséum National d'Histoire Naturelle, Paris. 
barnesii, A. peltatum, A. tuberculatum, A. tylophorum and $A$. tortuosum.

Distribution: India (southern Western Ghats) and Sri Lanka.

Specimens examined: INDIA, Kerala, Idukki district, Chunduvarrai to Mannavan Shola, 12.04.2013, Manudev \& Robi 135202, 135204 (CALI!); Eravikulam National Park, 19.07.1997, V. Abdul Jaleel \& Bobby Thomas 109 (CALI!); Kundala Dam to Mannavan Shola, 23.05.2015, Manudev 138962 (CALI!); Mannavan Shola, 23.05.2015, Manudev \& Syam Radh 138968 (CALI!); MunnarPoopara road, 03.09.2010, Manudev 4129 (CALI!); Peerumedu, 24.05.1997, V. Abdul Jaleel \& Bobby Thomas 60 (CALI!); Vallakadavu, Periyar Tiger Reserve, 17.11.1998, A. Johny 17955 (CALI!). Palakkad district, Kaikatty, Nelliyampathy, 07.05.1997, V. Abdul Jaleel \& Bobby Thomas 41 (CALI!); Minnampara, Nelliyampathy, 14.08.1977, V. Abdul Jaleel \& Bobby Thomas 120 (CALI!); Silent Valley, 01.06.1977, M. Sivadasan CU19182 (CALI!); Vengoli peak, south to Thunakkadavu dam, 28.04.1976, M. Sivadasan CU13149 (CALI!). Thiruvananthapuram district, Attayar, way to Athirumala, 07.06.2014, Manudev \& Arunkumar 138943 (CALI!); Agasthyamala, way to Athirumala, 11.06.2011, Manudev 4457; ibid., 07.06.2014, Manudev \& Arunkumar 138945 (CALI!); way to Pongalappara, Agasthyamala, 11.06.2011, Manudev 4466 (CALI!); Chemungi, 18.05.1979, \pm 900 m, $M$. Mohanan 61854 (CAL!). Tamilnadu, Dindigul district, Pulneys, banks of mountain streams, 1858, Beddome 115 (CAL!). Kanyakumari district, Muthukuzhivayal, 1450 m, 27.07.1977, A.N. Henry 49417 (CAL!); Nilgiris, s.loc., s.d., Perottett 1813 (P017050544); ibid., 06.1883, J.S. Gamble 11996 (CAL!); Nilgiris district, Coonoore, 31.07.1878, G. King s.n. (CAL!); Naduvattom, 06.1884, J.S. Gamble 14549 (DD!); Naduvattom, way to Ooty, near T.R. Bazar, 1795 m, 22.07.2012, Manudev 5277; Naduvattom to Ooty road, 2000 m, 22.07.2012, Manudev \& Santhosh Nampy 5279 (CALI!); Ooty, summit of Doddabeta peak, 12.05.2011, Manudev 4418 (CALI!); Rockland, Kundah-Coonoor road, 1885 m, 22.07.2012, Manudev \& Renab 5285 (CALI!); T.R. Bazar, near Naduvattom, Ooty, 12.05.2011, Manudev 4419 (CALI!); Yellakandy, Ooty-Avalanche road, $2104 \mathrm{~m}$, 22.07.2012, Manudev 5284 (CALI!); Ootacamund (Ooty),
12.09.1878, G. King s.n. (DD!); ibid., 05.1883, J.S. Gamble 11456 (CAL!); ibid., 06.1897, Bourdillon s.n. (CAL!). Telangana, Rangareddy district, Rudaram R.F., 21.08.1994, M. Silar Mohammed 12716 (SKU!).

Typification: Schott (1856) published A. huegelli Schott, based on the collections of Huegel possibly from southern India. He also published another species $A$. papillosum Steudel ex Schott, by validating the name by Steudel. Both the species, characterized by a cylindric to clavate appendix, found to be conspecific and were recognized as synonyms of $A$. leschenaultii Blume by Engler (1879), in his treatment of Araceae in de Candolle's Monographiae Phanerogamarum.

Arisaema papillosum was legitimately published by Schott (1856) in his Synopsis Aroidearum, based on the specimens from Steudel's personal herbarium. In fact, Schott wrote " $A$. papillosum Steudel (in Schedula)" means he had seen this name on the label of a sheet in Steudel's Herbarium. Schott did not cite any other details of the specimens in his protologue except for the type locality as "India Orientalis". Later he gave details of the specimens in the account of this taxa in his Prodromous Systematis Aroidearum as "Montes Nilaghirenses- Steudel- V. Specim. authentica" indicating the precise locality of the type as Mountains of Nilgiris in South India.

Ernest Gottleib von Steudel (1783-1856) was a German botanist and physician who collected only few plants himself and the majority of the plants in his herbarium were collected by others. There is no evidence that Steudel visited South India but he sometimes identified specimens for series of exsiccatae distributed by R.F. Hohenacker (German missionary, botanist and plant collector, 17981874) who explored South India and collected plants for sale in Europe. There are four sheets of Hohenacker under two collection numbers [No.1300 (3 sheets) and one sheet of No.1301] at Paris Herbarium (P). All these sheets are part of Steudel's herbarium as indicated in the field ticket attached in red ink. A lectotype is selected here (Hohenacker 1300, P1750545) conforming to the latest code of nomenclature (Turland et al., 2018)

Arisaema madhuanum Nampy \& Manudev, Edinburgh J. Bot. 71 (2): 269-273. 2014. Type: INDIA, Tamil Nadu, Coimbatore District, 
Valparai, Oosimala Top, $1344 \mathrm{~m}, 10^{\circ} 18.546 \mathrm{~N}$ 7659.987 E, 10.07.2012, Manudev \& Santhosh Nampy 5092 (holo CALI!; iso MH!).

Fig. 19

Deciduous, dioecious, perennial herbs, c. $115 \mathrm{~cm}$ tall. Subterranean stem a tuberous corm, depressed globose or subglobose, $3-4.5 \mathrm{~cm}$ diam., $2-3 \mathrm{~cm}$ tall, brownish, wrinkled, cream inside; offsets $c$. 8 , surrounding the pseudostem, purplish or dark brown-black, globose, sometimes one or two below the roots slightly elongated. Roots many, on top of the corm surrounding the pseudostem, rose-tinged. Cataphylls 3, rarely 4 (fourth one usually disintegrated); outer $1.8-3 \mathrm{~cm}$ long, pale brown, apex acute-obtuse, mucronulate, slightly keeled; middle 12-16 cm long, brown-purple with greenish-white or cream mottling/lesions, apex obtuse or orbicular, mucronate; inner 30$39 \mathrm{~cm}$ long, brown-purple with greenish white or cream mottling, obtuse or orbicular at apex, mucronate. Leaf single, radiatisect, probably emergin with or after the inflorescence; petiole $38-50 \mathrm{~cm}$ long, $0.5-2 \mathrm{~cm}$ thick, pale green with brown mottling formed of vertical streaks; leaflets 7-10, sessile, obovate-spathulate, 13-40 cm long, 2.2-11 cm wide, subequal, gradually cuneate at base, acuminate at apex, margins entire, undulate, bright green above, pale beneath, lateral veins up to 25 pairs, intra-marginal vein $c .0 .5 \mathrm{~cm}$ apart from the margins. Pseudostem $35.5-50 \mathrm{~cm}$ long, pale green with brown mottling, ligule not prominent. Inflorescence held below the leaf; peduncle 33.5-66 cm long, $0.5-0.7 \mathrm{~cm}$ thick, mottled as in petiole, pale purple towards the distal end, exserted by $5-17 \mathrm{~cm}$ from the pseudostem. Spathe 18-20 cm long including the limb portion; tube of spathe cylindric, funnel-shaped towards the mouth, 8-9 cm long, 1-2.5 cm wide, pale to purple basally, greenish distally, dark purplish within, with white longitudinal stripes along the veins; mouth open, wide, margins dilated into a prominent auricular extension about $1 \mathrm{~cm}$ wide, margins of auricle slightly revolute, $c .4 .5 \mathrm{~cm}$ wide in the mouth region and suddenly narrowing into the limb; limb oblong-lanceolate, 10-11 cm long, 2-2.5 cm wide, yellowish-green with 5 white to hyaline longitudinal stripes along the veins, two paler stripes flanking three larger stripes in the middle, margins curved back at the base of the limb forming a neck-like constriction immediately after the mouth, apex acuminate with a slightly swollen tip, erect and arching forward at the distal end. Female spadix not seen. Male spadix sessile, just reaching the mouth, $8-9 \mathrm{~cm}$ long, slender, terete; fertile region $2.5-3.3 \mathrm{~cm}$ long at the base; male flowers sessile or shortly stipitate towards the distal end of the fertile zone, 2-9-androus; stipe to $c .1 \mathrm{~mm}$ long; anthers reniform, purple, dehisce through an apical pore; neuters $8-9$, subulate, 2-6 $\mathrm{mm}$ long, scattered along the basal $1-1.5 \mathrm{~cm}$ of the appendix, curved down, often paired from the base, purplish-green; appendix sessile, base slightly thickened, c. $0.3-0.5 \mathrm{~cm}$ wide, gradually tapering to a filiform often curved distal portion, purplish basally and greenish distally to a filiform apex. Fruiting spike cylindrical, 4-6 cm long, 2.5-3.5 $\mathrm{cm}$ wide, borne on an upright peduncle; berries ovoid to globose, compactly arranged, green when young, 2-seeded.

Flowering \& fruiting: Probably from the onset of monsoon; flowers and young fruits observed in July.

Habitat: Grows along the margins of evergreen forests near tea plantations at Oosimala Top, above $1300 \mathrm{~m}$. A population of 31 plants was observed at the type locality, including two fruiting female plants. One of the infructescences had remnants of the spathe tube as well as a dried filiform appendix at the apex. The female plants were robust and larger than the male plants.

Distribution: India (southern Western Ghats), endemic.

Specimen examined: Kerala, Idukki district, Eravikulam National Park, 18.07.1997, V. Abdul Jaleel \& Bobby Thomas 107 (CALI!).

Notes: Arisaema madhuanum is morphologically close to $A$. attenuatum and $A$. tylophorum, both endemic to the southern Western Ghats, in having a slender to almost filiform appendix. However, the new species can be easily distinguished from both of them by having a wide-mouthed spathe tube, and by the erect to arching limb with a narrow base.

Arisaema nilamburense Sivad. in Sivad. \& Nicolson, Aroideana 6: 37. 1983; Manilal, Fl. Silent Valley 332. 1988; Sivarajan \& Mathew, Fl. Nilambur 753. 1997; Sivad., in Manoharan et al., Silent Valley- Whispers of Reason 237. 1999; 


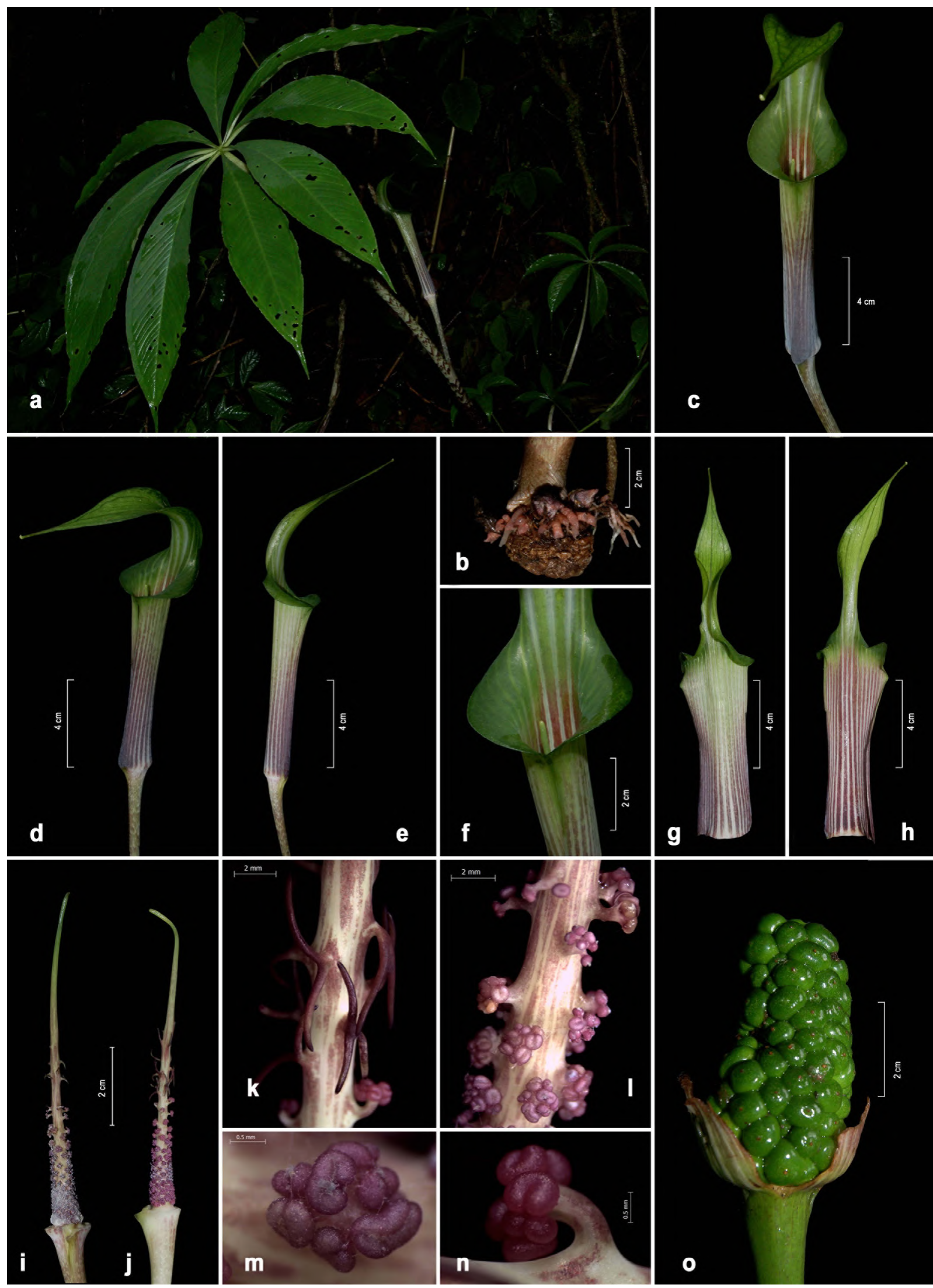

Figure 19. Arisaema madhuanum Nampy \& Manudev: a. Habit; b. Corm with cormlets; c. Male inflorescence-front view; d-e. Male inflorescenceside views; f. Mouth of the spathe tube; $\mathbf{g}-\mathbf{h}$. Spathe; I. Male spadix; j. Neuters; $\mathbf{k}$. Male fertile region; I \& m. Male flowers. $\mathbf{n}$. Fruiting spike. 
Gusman \& L.Gusman, Gen. Arisaema, ed. 2. 395. 2006. A. auriculatum E.Barnes, Kew Bull. 1946: 44. 1946; Chatterjee, Bull. Bot. Soc. Bengal 8: 121. 1959, non Buchet (1911), non Smith 1914, non Kishida 1931. Lectotype (designated by Sivadasan \& Nicolson, 1983): INDIA, Kerala, Nilambur Ghat, Nilgiri, Wayanad, 2500 ft, July 1940, Barnes 2285 (K000499459 digital image!).

Fig. 20

Deciduous, dioecious, succulent, perennial herbs, 50-90 cm tall. Subterranean stem a tuberous corm, globose-subglobose $3.5-5 \mathrm{~cm}$ diam., 2-3 $\mathrm{cm}$ wide, white-cream, wrinkled, stoloniferous. Roots arising from the upper side of the corm, white to flesh coloured. Cataphylls 3 or 4, rarely 5: outer $4.5-5 \mathrm{~cm}$ long, acute-obtuse at apex, slightly mucronate, rose coloured; middle 9.5-13 cm long, rose to flesh coloured; inner $20-27 \mathrm{~cm}$ long, rose-brown, with white or awful white dots, almost reaching to the length of pseudostem; often a forth outer cataphyll may also present, $c$. $2 \mathrm{~cm}$, rose to pale coloured and sometimes with a fifth degenerated one. Leaf solitary, radiatisect, emerging after the inflorescence; petiole slender, $c$. $90 \mathrm{~cm}$ long, green with rose to brownish patches, often glaucous; leaflets sessile, 5-7 or rarely 3 in vegetative plants, obovate-oblanceolate, sometimes elliptic, $13.5-25 \mathrm{~cm}$ long, $4-10 \mathrm{~cm}$ wide, cuneate at base, acute-acuminate or caudate, margins minutely praemorse, with a white or hyaline dorsal border, dark green ventrally, glaucous beneath, lateral veins 15-20 pairs. Inflorescence not exceeding the height of the leaf, usually held below; peduncle slender, 30-45 $\mathrm{cm}$ long, exserted by $c .8 \mathrm{~cm}$ from the sheathing pseudostem, light green-greenish white, often glaucous. Spathe 14-16 cm long; tube of spathe cylindric at base, slightly funnel-shaped towards the mouth region, $6.5-8 \mathrm{~cm}$ long, $1.2-1.5 \mathrm{~cm}$ wide, white with purplish-brown bands along the length of the tube, bands are lighter outside, darker inside; margins of the mouth dilated in to a notably revolute, rounded auricle; limb, slightly cucullate at the base, obovate or widely obovate, 7-8.5 cm long, 3-5 cm wide, narrowly acuminate or caudate at apex, brownish green with basal white bands; nerves brown to purplish, anastomosing, with an intra marginal vein; margin slightly undulate with a purple band; distal half of the limb arched over and drooping. Female spadix sessile, c. $9 \mathrm{~cm}$ long, c. $1 \mathrm{~cm}$ thick; female fertile region c. $3 \mathrm{~cm}$ long, followed by neuters; pistils many, compactly arranged along c. $2.5 \mathrm{~cm}$ long, subglobose, green; ovules 2 or 3 , stigma papillate, stellate, nearly sessile; neuters echinate, few, 2-3 mm long, scattered over a distance of $c$. $1 \mathrm{~cm}$, upcurved, white or purplish buff often with purplish spots; appendix stipitate with a swollen base after neuters, tapering to distal end and just reaching the mouth of the tube, arching forward at the apex, green with purplish discontinuous bands or dots, smooth or glabrous except the rugose, distal curved portion with purple spots. Male spadix stipitate, similar to female but slender, 7-7.5 cm long, 0.4-0.7 cm thick, naked or sometimes with few short echinate neuters; flowers scattered over or crowded at the base and distant above, sessile or decidedly stipitate, 2 or 3-androus; anthers purple-bluish, dehisce by an apical pore. Fruiting spike cylindric or conical, $c$. $9 \mathrm{~cm}$ long, c. $4 \mathrm{~cm}$ wide, borne on an upright peduncle; berries ovoid compactly arranged, green when young, orange to bright red upon maturity, 2 or 3-seeded.

Flowering \& fruiting: May-June.

Habitat: In grasslands, shola forests and evergreen forests, between 500-1200 m, usually found in clumps, as well as in soil pockets of wet rocks near the streams.

Distribution: India (southern Western Ghats), endemic.

Specimens examined: INDIA, Kerala, Kozhikode district, Muthappanpuzha, way to Olichuchattom, 08.05.2011, Manudev \& Santhosh Nampy 4414 (CALI!). Malappuram district, Karimpuzha, 06.08.1983, Philip Mathew 34206 (CALI!). Palakkad district, Silent Valley, Dam site, 26.05.1982, Sathish Kumar 10587 (CALI!). Kottayam district, Vagamon, Kurisumala, 17.08.2013, in fruiting, Manudev \& Robi Jose 135330 (CALI!). Wayanad district, Kurichiarmala, 28.10.2013, in fruiting, Arunkumar \& Santhosh Nampy 142284 (CALI!); ibid., 27.11.2014, in fruiting, Santhosh Nampy \& Manudev 139982 (CALI!); Vythiri, Thalamala, 29.05.2011, Manudev \& Santhosh Nampy 4441(CALI!).

Notes: This species was first described by Barnes in 1946 under the name $A$. auriculatum owing to the auriculate nature of spathe, a character found 

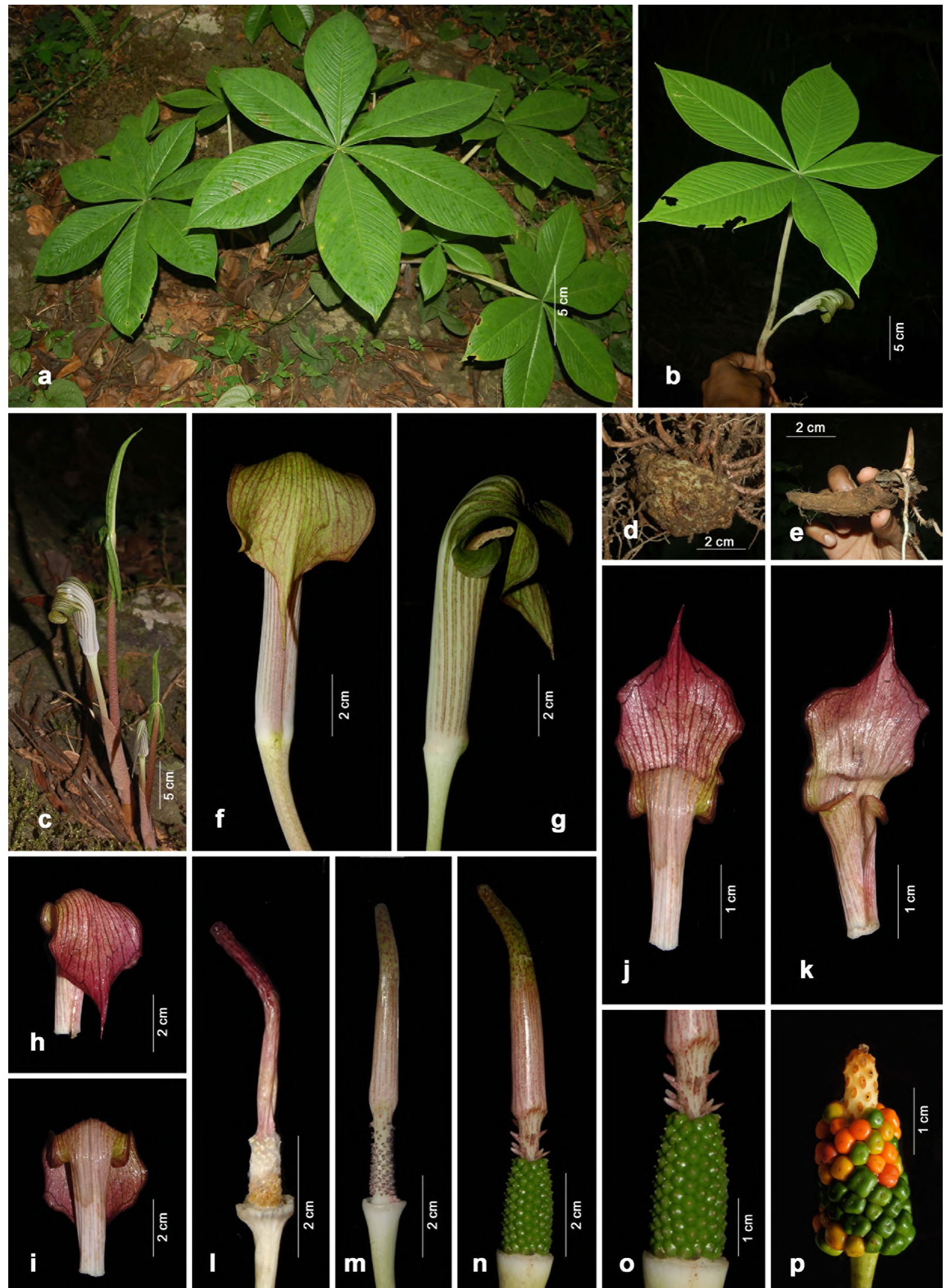
in many species of Arisaema, which was served as the basis for naming as many as three taxa previously ( 2 from China and 1 from Japan). Since the epithet 'auriculatum' was preoccupied, Sivadasan and Nicolson (1983) renamed this species as $A$. nilamburense Sivad., after the type locality, Nilambur. A lectotype was also selected from the collections of Barnes from Nilambur Ghats (Barnes 2285).

Arisaema peerumedense J.Mathew, Ann. Bot. Fennici 54: 29. 2017. Type: INDIA, Kerala, Idukki district, Peerumedu, tract to Parunthumpara, 1350 m, 14.06.2015, J. Mathew 4824 (holo TBGT; iso SESH).

Fig. 21

Dioecious, perennial herbs, to $1.75 \mathrm{~m}$ tall. Corms globose to subglobose, 3-5 diam., $2-2.5 \mathrm{~cm}$ tall, cream-white, stoloniferous. Cataphylls 3 or 4: outer $c .3 .5 \mathrm{~cm}$ long, acute-obtuse at apex, pale rose to white coloured; middle $8-10 \mathrm{~cm}$ long, rose to flesh coloured; inner 19-20 cm long, rose-brown, with white or purplish dots, almost reaching to the length of pseudostem; often a forth outer cataphyll may also present, c. $1.5 \mathrm{~cm}$, rose to pale coloured.
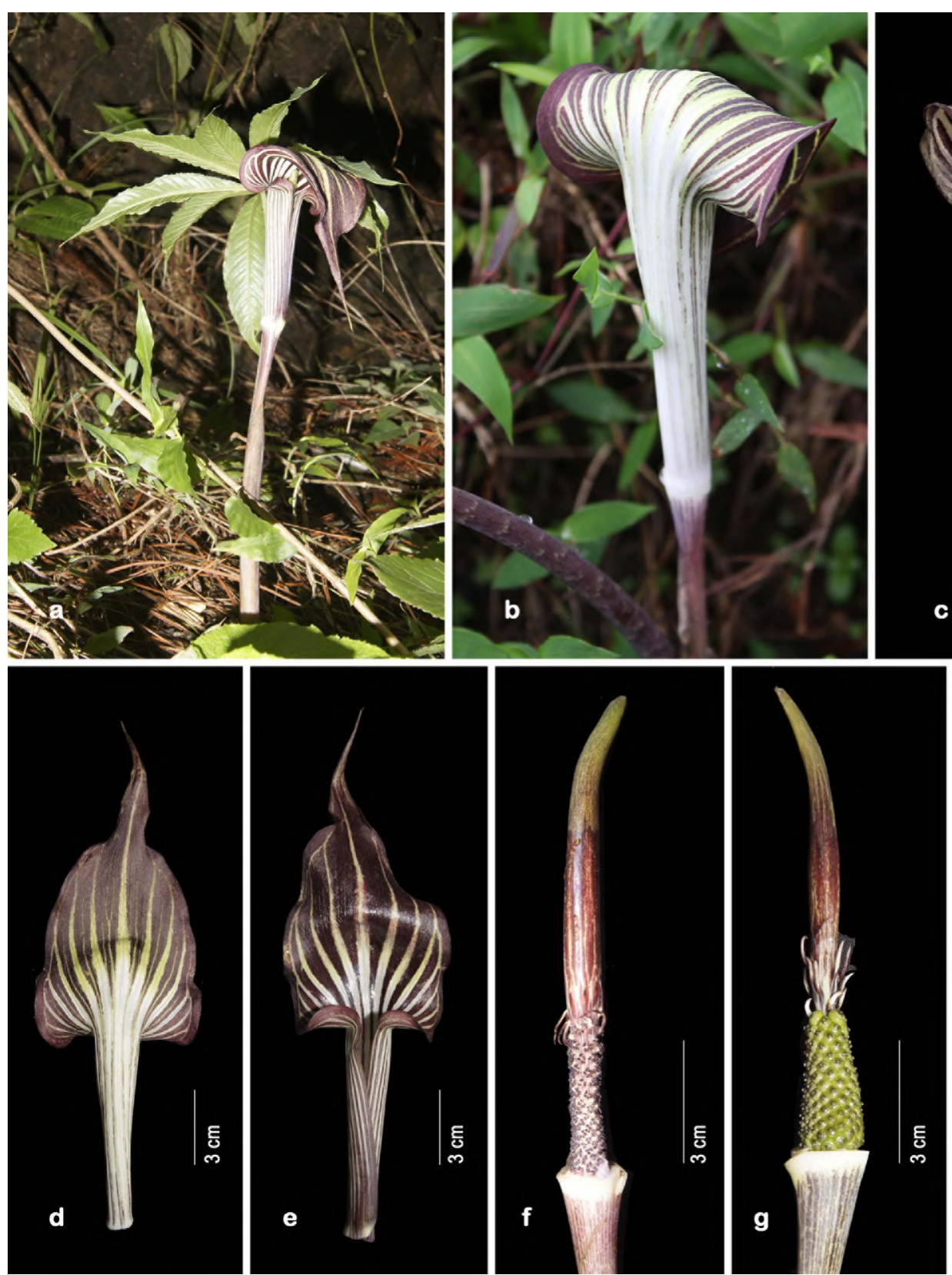

C

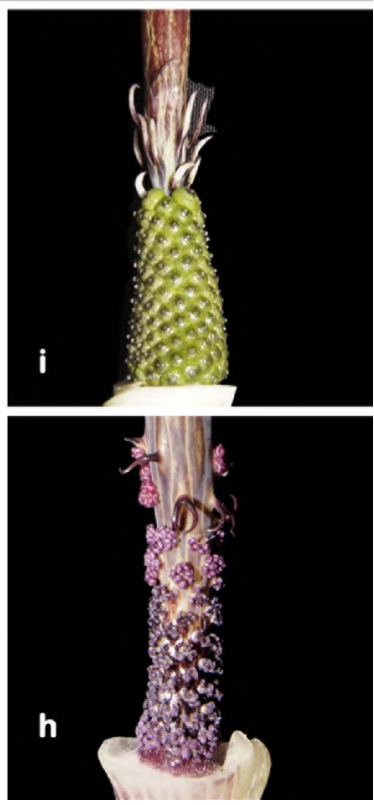

Figure 21. Arisaema peerumedense J.Mathew: a. Habit; b. Inflorescences; c-e. Spathe (c \& d. front view; e. back view); f. Male spadix; g. Female spadix; h. Male floriferous region; i. Female floriferous region. 
Leaf solitary, rarely 2 ; petiole $c .125 \mathrm{~cm}$ long, petiole slender, c. $125 \mathrm{~cm}$ long, 1-2.5 cm thick, brownish green mottled with pink; leaflets radiatisect, 8-12, 22-35 cm long, 5-9 cm wide, lanceolate, base cuneate, narrowly acuminate, margins entire, wavy, bright green above, pale beneath, margins greenish to hyaline, lateral veins up to 25 pairs, intra marginal vein $c .0 .5 \mathrm{~cm}$ apart from the margins. Spadix dioecious, not exceeding the height of the leaf; peduncle slender, 100-142 cm long, 1.5-3.5 $\mathrm{cm}$ long thick, exserted by $7-18 \mathrm{~cm}$ from the sheathing pseudostem, greenish purple. Spathe 20-30 cm long; tube of spathe cylindric towards base, funnel-shaped distally, 5-11 cm long, 1.5$2.5 \mathrm{~cm}$ broad, light purple towards the base, pale purple distally, dark purple within with greenishwhite bands over the veins; margins of the mouth auriculate, dilates in to a prominent auricular extension c. $2.5 \mathrm{~cm}$ wide; limb oblong-lanceolate, purple with greenish white bands, 24-26 × 8-9 $\mathrm{cm}$, narrowly acuminate at apex, tapering in to a slender tail, arching forward, thus reaching the tip almost to the base of the tube. Female spadix sessile, c. 11.5-15 cm long, 1-2 cm wide; fertile region of $3.5-4 \mathrm{~cm}$, followed by neuters along c. $2 \mathrm{~cm}$; pistils many, sessile, compactly arranged, globose, green; ovules 3-5, white; stigma papillate, stellate, sessilesubsessile, often with a dark neck; neuters subulate, few, 0.5-1 cm long, scattered, upcurved, white to purple, appendix, cylindric-fusiform, broader at middle, tapering to both sides, reaching the mouth of the tube or just exceeding, blunt at apex, slightly curved distally, green to light green, purplish below. Male spadix sessile, similar to female, slender, c. 13 cm long, 1-1.5 cm thick; fertile region c. $4 \mathrm{~cm}$ long, male flowers scattered over or crowded at the base and distant above, sessile, 3-5-androus; anthers sessile, purple, dehisce by an apical pore; neuters few, subulate, c. $1 \mathrm{~cm}$ long, purplish. Fruiting spike cylindrical, borne on an upright peduncle; berries globose, compactly arranged, c. 3-seeded.

Flowering \& fruiting: June-July.

Habitat: Grows in shola evergreen forests, under shaded conditions at an elevation above $1350 \mathrm{~m}$.

Distribution: India (southern Western Ghats), endemic.

Specimen examined: INDIA, Kerala, Idukki district, Peerumedu, 30.06.2016, Arunkumar 149282 (CALI!).
Notes: A. peerumedense is closely related to $A$. leschenaultii Blume but can be distinguished by its sessile, distally curved, cylindric-fusiform spadix appendix. The authors have also encountered intermediates between these two taxa in southern Western Ghats which render the identification of these two taxa dubious.

Arisaema peltatum C.E.C.Fisch., Bull. Misc. Inf. Royal Gard. Kew 1936(4): 277. 1936; Chatterjee, Bull. Bot. Soc. Bengal 8: 130. 1955; Manudev \& Nampy, ENVIS News Lett. 20(1): 4. 2015. Type: INDIA, Kerala, Idukki district, Munnar, 12.06.1935, E. Barnes 1147 (K000203012 digital image!).

A. leschenaultii auct. Gusman \& L. Gusman, Arisaema ed. 2. 392. 2006, pro parte, non Blume 1836. Fig. 22

Deciduous, dioecious, succulent, perennial herbs, 38-130 cm tall. Subterranean stem a tuberous corm, globose, $2.5-4.5 \mathrm{~cm}$ diam., 1-2 cm wide, smooth or wrinkled, stoloniferous. Cataphylls 2 or 3, acute-obtuse at apex; outer $2-6.5 \mathrm{~cm}$ long, pale coloured, often mottled with brownish streaks in mature plants; middle 6-13.6 cm long, mottled with brownish patches or streaks; inner 17-45 cm long, strongly mottled, darker. Leaf solitary, radiatisect, emerging after the inflorescence; petiole slender, 38-65 cm long, 0.8-1 cm thick, light green mottled with brownish streaks; leaflets 5-10, oblong-oblanceolate, 15-34 cm long, 2-10 $\mathrm{cm}$ wide, cuneate at base, narrowly acute to acuminate, margins greenish to hyaline, praemorse, strongly undulate (appears to be serrate), darker above, glaucous or whitish beneath, lateral veins up to 26 pairs, intra marginal vein $0.4-0.6 \mathrm{~cm}$ apart from the margins. Inflorescence not exceeding the height of the leaf; peduncle slender, 25-90 cm long, $1.5-3.5 \mathrm{~cm}$ long, exerted by $8-14 \mathrm{~cm}$ from the sheathing pseudostem, light green with purplish mottling towards the distal portion. Spathe 13-30 cm long, glossy in texture; tube of spathe cylindric towards base, funnel-shaped distally, 5-11 cm long, c. $2.5 \mathrm{~cm}$ broad, purple to brownish towards the base, greenish distally with white bands over the veins; margins of the mouth revolute; limb ovate-lanceolate, $8.5-19 \mathrm{~cm}$ long, 3-6 cm wide, greenish with white bands; bands wider towards the base and narrower towards the apex, narrowly acuminate at apex, tapering in to a slender tail, arching forward and upcurved with erect tip or 


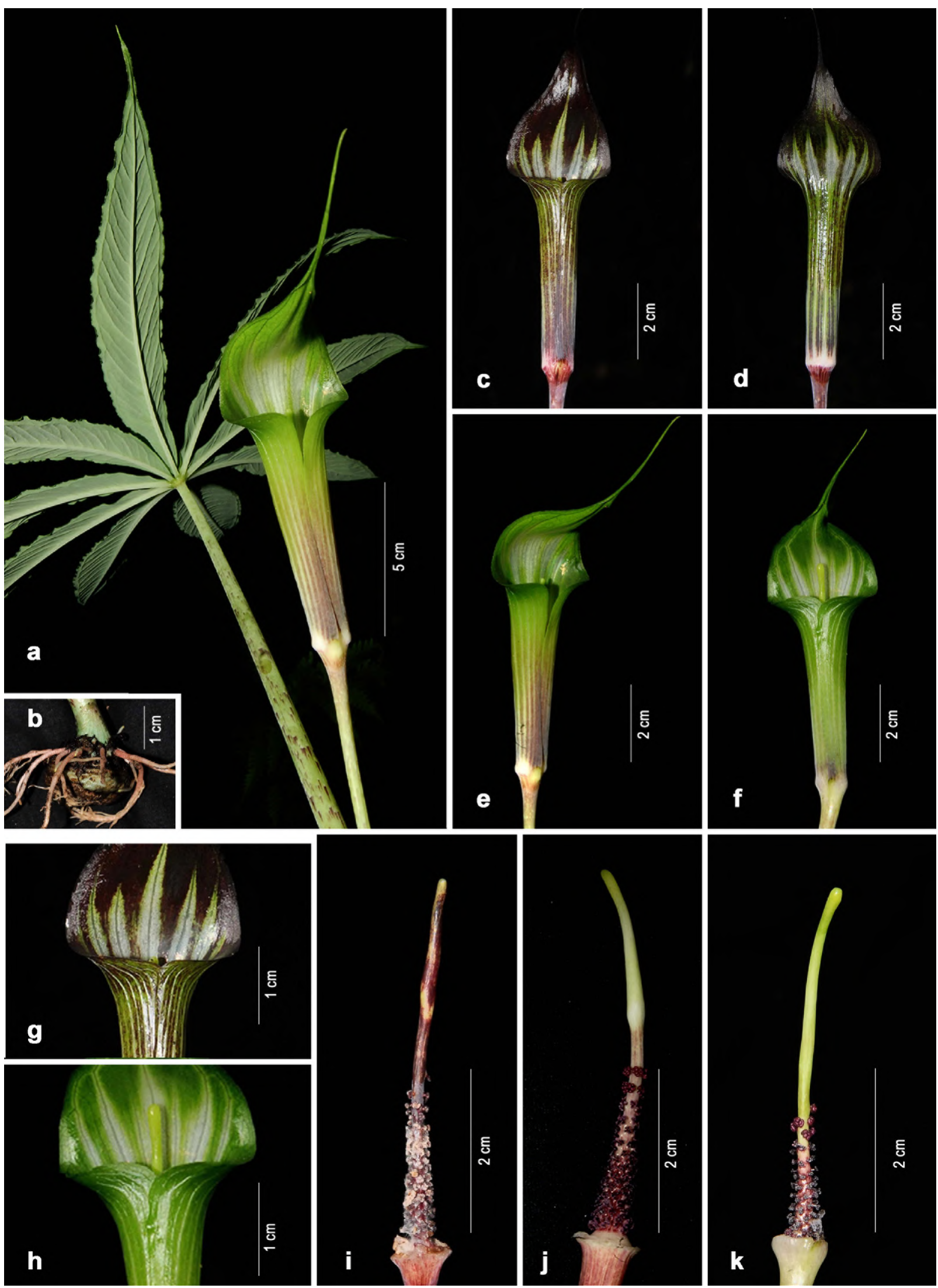

Figure 22. Arisaema peltatum C.E.C.Fisch.: a. Habit; b. Corm; c-f. Inflorescences (c \& d. Purple form; e \& f. Green form); $\mathbf{g}$ \& h. Mouth of the tube with straight margins; i-k. Male spadices.. 
often drooping (probably after anthesis), thus reaching the tip almost to the base of the tube. Female spadix sessile, $c .12 .6 \mathrm{~cm}$ long, $0.6-0.7 \mathrm{~cm}$ thick; female fertile region $c .4 \mathrm{~cm}$ long, followed by neuters along $c .4 \mathrm{~cm}$; pistils many, compactly arranged, green; ovules up to 5, white; stigma papillose, stellate, sessile; neuters subulate, many, $0.7-1.2 \mathrm{~cm}$ long, scattered, upcurved, pale to purplish; appendix cylindric, reaching the mouth of the tube or just exceeding, blunt at apex, slightly curved distally, green to light green, purplish below. Male spadix sessile, slender, slightly tapering to a blunt tip, $4.5-6.5 \mathrm{~cm}$ long, not exceeding the tube or just reaching the mouth; appendix sessile, slightly thickened at the base and appears to be stipitate, 2.5-3.5 cm long; male flowers scattered over $2-3 \mathrm{~cm}$ along the spadix, sessile or subsessile, 3-4-androus; anthers, purple, dehisce by an apical pore; neuters absent. Fruiting spike not seen.

Flowering: May-July.

Habitat: In grass lands and shola forests at an elevation above $1200 \mathrm{~m}$ above sea level.

Distribution: India (southern Western Ghats), endemic.

Specimens examined: INDIA, Kerala, Idukki district, Munnar-Poopara road, 23.05.2011, Manudev \& Santhosh Nampy 4432 (DEV!); Kundala to Mannavan Shola, on the way, 23.05.2015, Manudev E Syam Radh 138961; Munnar-Pallivasal, 12.05.1935, E. Barnes 1146 (K digital image!, CALI!); Mannavan Shola National Park, on the way to Kanthallur, 23.05.2015, Manudev \& Syam Radh 138964, 138967 (CALI!); Travancore, few miles above Munnar, s.d., E. Barnes 1115(3) (K paratype, digital image!).

Notes: This species is recently rediscovered by Manudev and Nampy (2015) and is characterized by radiate leaflets, flagellate-caudate limb and rounded clavate spadix appendix, often with neuters at the base. However this species shows some deviation from the typical characters of the Sect. Sinarisaema-spadix appendage being slender and slightly tapering towards the apex, neuters present along the half way of appendix. Gusman and Gusman (2006) assigned this species as a synonym of $A$. leschenaultii Blume along with few other species from southern India and Sri Lanka, considering the latter as a polymorphic species.
However, this species is quite distinct and can be distinguished from the latter by its sessile, narrow leaflets with strong wavy margins and glaucous underneath; hyaline to white-striped, yellowishgreen limb tapering into a slender tail and sessile, slender, spadix appendix with neuters along half the length.

Arisaema psittacus E.Barnes, Hooker's Icon. Pl. 35: t. 3405. 1940; Chatterjee, Bull. Bot. Soc. Bengal 8: 131. 1955; Gusman \& L.Gusman, Gen. Arisaema, ed. 2. 397. 2006. Type: INDIA, Kerala, Idukki district, Mannavan Shola, 1937, E. Barnes 1576 (K000499328 digital image!)

Fig. 23

Deciduous, dioecious, succulent, perennial herbs, $c$. $1 \mathrm{~m}$ tall. Subterranean stem a tuberous corm, 2.5-5 cm diam., 2-2.5 cm tall, stoloniferous, greenish yellow inside. Roots many, from the upper side of the corm, white to pale pink. Cataphylls 2 or 3 rarely 4 , obtuse-orbicular at apex; outer c. 1-2 cm long, pale to white; middle 3-28 cm long, purplish to greenish brown, dark brown mottled with longitudinal streaks, sometimes pale white without any mottling; inner 7-69 cm long, enclosing the pseudostem, purplish to greenish brown, dark brown mottled with longitudinal streaks, sometimes pale white without any mottling, cylindric below. Leaf solitary, radiatisect, usually unfolds with the emergence of inflorescence; petiole $22-56 \mathrm{~cm}$ long, 0.3-1.2 cm wide, dark green, brownish green, dark brown mottled with longitudinal streaks, sometimes pale white to green without any mottling; leaflets 7-13, sessile, obovate, 7-35 cm long, 2-8 cm wide, base cuneate, acute at apex, margins serrulate, often wavy or undulate, dark green ventrally, pale dorsally. Pseudostem 8-77.5 cm long, 1-2.5 cm thick, wrapped by cataphylls, mottled as in petiole. Inflorescence held below the leaf; peduncle 21-92 cm long, mottled as in petiole, exserted by $12-14 \mathrm{~cm}$ from the sheathing pseudostem. Spathe 13-28 cm long; tube of the spathe funnel-shaped, 3-angled, 5.5-9 cm long, $1.2-3 \mathrm{~cm}$, green, pale green or brownish green with white stripes along the veins; mouth margins staright or slightly recurved; limb cucullate, 7.5$19 \mathrm{~cm}$ long, 2.5-5.5 cm wide, green or brownish green with c. 5 wide, translucent or white stripes, gradually acuminate apex ending in a tail 4-10 $\mathrm{cm}$ long, drooping downward and curved like a parrot beak. Female spadix sessile, $8-10.5 \mathrm{~cm}$ long, 


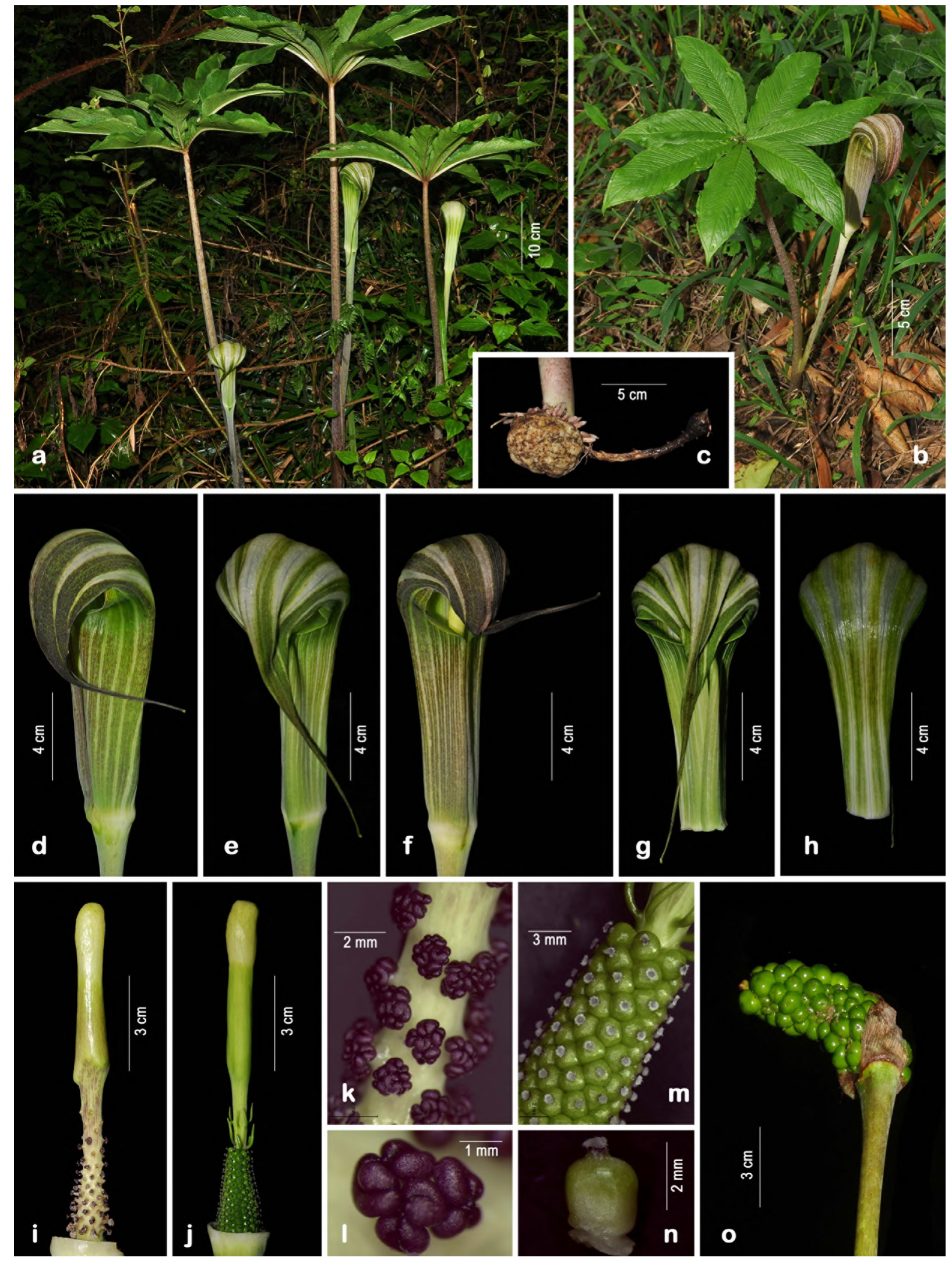

Figure 23. Arisaema psittacus C.E.C.Fisch. a \& b. Habit; c. Corm with stolon; d-f. Inflorescences; g. Spathe-front view; h. Spathe-back view; i. Male spadix; j. Female spadix; k. Male floriferous region; I. Male flower-enlarged view; m. Female floriferous region; n. Female flower-enlarged view; o. Fruiting spike borne on an erect peduncle. 
0.9-1.5 cm thick; female fertile region $2.2-2.7 \mathrm{~cm}$ long, followed by few neuters; pistils many, sessile, compactly arranged, bottle-shaped, green; stigma papillose and white with black neck; neuters few, subulate, $0.5-1 \mathrm{~cm}$ long, upcurved, green; appendix cylindric, slightly longer than the tube, inserted inside the spathe, $8-8.5 \mathrm{~cm}$ long, $0.5-1 \mathrm{~cm}$ thick, greenish-yellow, constricted in the middle, ending in a knobby ovoid, verruculose, and yellow apex. Male spadix sessile, similar to female, slender, $6.5-8 \mathrm{~cm}$ long; fertile region narrow, $2-2.5 \mathrm{~cm}$ long, green-yellow; male flowers scattered over or crowded at the base and distant above, shortly stipitate with 3-4-androus; anthers purplish, deshisce by an elliptic pore; neuters absent. Fruiting spike cylindric to conical, c. $13.5 \mathrm{~cm}$ long, 3.5-5 $\mathrm{cm}$ wide, borne on an upright peduncle; berries orange-red, compactly arranged, 3-6-seeded.

Flowering \& frtuiting: May-September.

Habitat: Grows under shades in wet evergreen forests, in moist humus rich soil.

Distribution: India (southern Western Ghats), endemic.

Specimens examined: INDIA, Kerala, Idukki district, Mannavan Shola, 05.1937, E. Barnes 1579, 1680 (MH!); ibid., 23.05.2015, Manudev \& Syam Radh 138963 (CALI!); ibid., towards Kanthallur, 23.05.2015, Manudev \& Syam Radh 138966 (CALI!).

Notes: This species is is close to A. leschenaultii from which it can be easily distinguished by its cucullate spathe with a curved tail, dialated ovoid, verruculose spadix appendix with a constriction in the middle.

Arisaema sarracenioides E.Barnes \& C.E.C.Fisch., Hooker's Icon. Pl. 34: t. 3307. 1936; Chatterjee, Bull. Bot. Soc. Bengal 8: 135. 1955; Gusman \& L.Gusman, Gen. Arisaema, ed. 2. 398. 2006. Type: INDIA, Kerala, Idukki district, Munnar, Naimakad gap, c. 6500 ft, E. Barnes 1092 (K000400314 digital image!)

Fig. 24

Deciduous, dioecious, succulent, perennial herbs, c. $70 \mathrm{~cm}$ tall. Subterranean stem a tuberous corm, depressed globose to subglobose, 2.5-4 cm diam., 2-3 cm tall, yellow to greenish yellow inside, offsets often present in mature corms, a few, surrounding the pseudostem. Roots many, from the upper side of the corm. Cataphylls 3, acute or obtuse-orbicular at apex, mucronate; outer 1.5-2.5 $\mathrm{cm}$ long, pale to white often blushed with rose; middle $c .7 \mathrm{~cm}$ long, pale white-green or brownish, faintly brown mottled; inner 15-16 cm long, enclosing the pseudostem, pale green to greenish brown, with faint or dark rose, purple to brownish mottling. Leaf solitary, radiatisect, usually unfolds completely after the emergence of inflorescence; petiole $40-70 \mathrm{~cm}$ long, $0.5-1.3 \mathrm{~cm}$ thick, light green to dark brownish green, pale-brown to purplish-brown mottled; leaflets $5-7$, petiolulate, elliptic-obovate or oblanceolate, $14-30 \mathrm{~cm}$ long, 4-9 $\mathrm{cm}$ wide, cuneate at base with a petiolules $1-1.5 \mathrm{~cm}$ long, acute-acuminate at apex, margins entire, undulate, serrulate, dark green ventrally, pale dorsally. Pseudostem 17-19 cm long, 1-2 $\mathrm{cm}$ wide, wrapped by cataphylls, mottled as in petiole. Inflorescence held below the leaf; peduncle 22-26 cm long, much shorter than petiole, light green, pale to dark brown or purple mottled, always greenish distally, sometimes green all over without any mottling, exserted by $5-9 \mathrm{~cm}$ long from the pseudostem. Spathe 18-22 cm long; tube of spathe cylindric below, funnel-shaped towards the mouth, 6-8 cm long, $1.5-3 \mathrm{~cm}$ wide, white with longitudinal purple stripes along the veins; margins of the mouth recurved; limb cucullate, with a narrow opening, 6-8 cm long, c. $4 \mathrm{~cm}$ wide, white purple stripes, ending in a terminal, ovate, hanging lobe; lobe green outside with purple veins, dull purple or green and purple inside, $c$. $6.5 \mathrm{~cm}$ long, 5-6 cm wide, ending in a short tail. Female spadix sessile, $10.5-11.5 \mathrm{~cm}$ long, $0.8-1 \mathrm{~cm}$ thick, conical with a narrow fertile region of 2-2.5 $\mathrm{cm}$ at the base, followed by few neuters; appendix stipitate, $8-9 \mathrm{~cm}$ long, cylindric, exserted from the spathe tube, fusiform with $0.5-0.8 \mathrm{~cm}$ thick at base and gradually tapering to a verrucose apex, white or white with purple markings; neuters subulate, few, 0.5-1 cm long, upcurved, white; pistils many, sessile, compactly arranged, globose, green; ovules 3-5, white; stigma papillose, white, sessilesubsessile, often with a dark blue neck. Male spadix sessile, similar to female, slender, $8-10 \mathrm{~cm}$ long; fertile region c. $2.5 \mathrm{~cm}$ long; male flowers scattered over or crowded at the base and distant above, stipitate, 4-6-androus; anthers sessile, purple, dehisce by an elliptic pore; neuters absent. Fruiting spike cylindric, borne on an erect peduncle; berries 


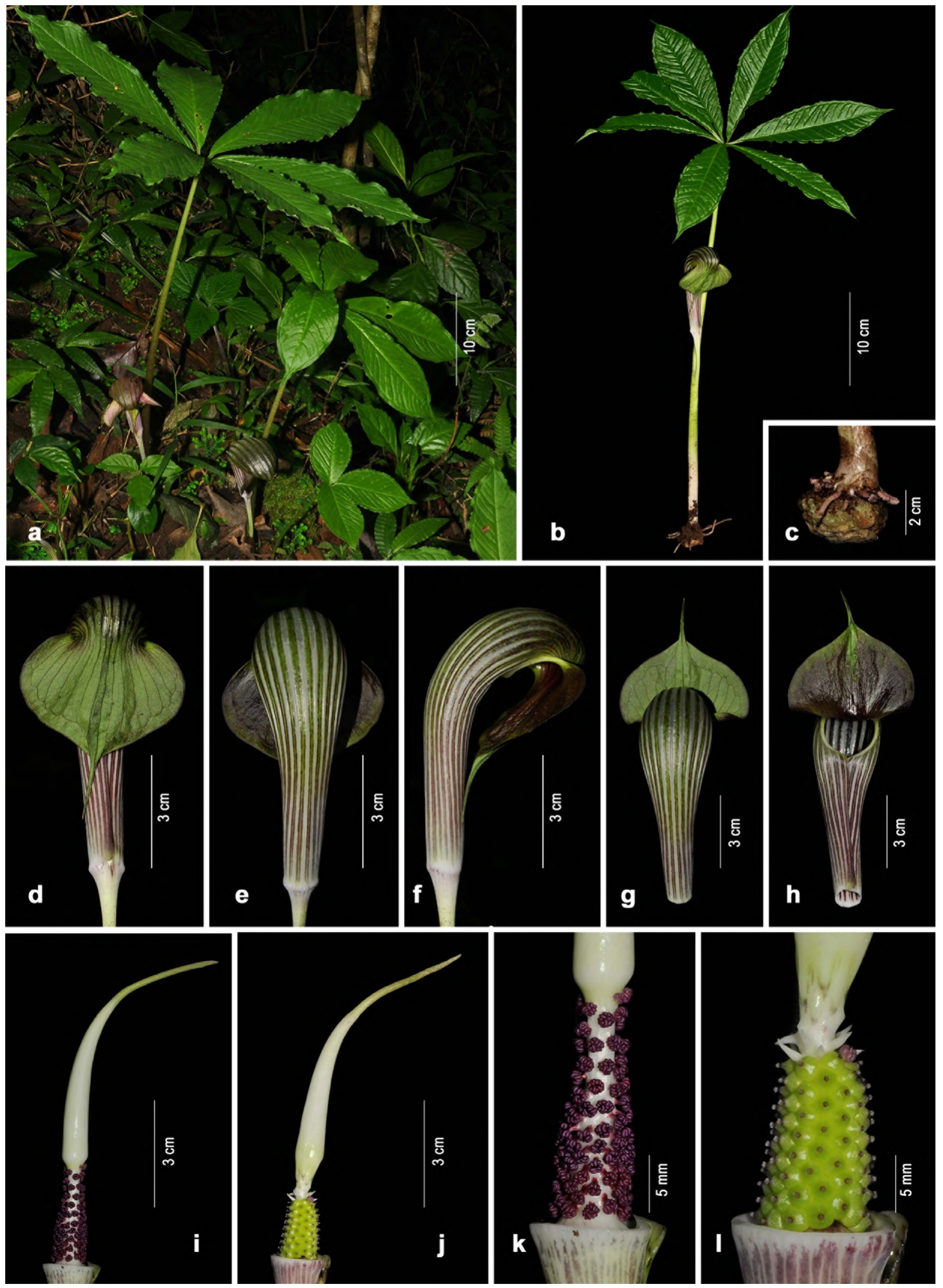

Figure 24. Arisaema sarracenioides E.Barnes \& C.E.C.Fisch.: a \& b. Habit; c. Corm; d-f. Inflorescences; g. Spathe-back view; h. Spathe-front view; i. Male spadix; j. Female spadix; k. Male floriferous region; I. Female floriferous region. 
globose, compactly arranged, red, 2-4-seeded.

Flowering \& fruiting: May-October.

Habitat: In evergreen forests, shola margins, among bushes, in humus rich soil at an elevation above $1500 \mathrm{~m}$, in association with $A$. attenuatum, $A$. psittacus and A. leschenaultii.

Distribution: India (southern Western Ghats), endemic.

Notes: This species is close to $A$. translucens in its cucullate spathe limb from which it can be easily distinguished by the presence of a terminal hanging ovate lobe at the spathe apex.

Specimens examined: INDIA, Kerala, Idukki district, Devikulam, Lockhart gap, 23.05.2011, Manudev E Santhosh Nampy 4433 (CALI!); Eravikulam National Park, Nymakad, 20.07.1997, V. Abdul Jaleel \& Bobby Thomas 112 (CALI!); Mathikettan Shola National Park, Chekpost to Onnamthodu, 22.05.2015, Manudev \& Syam Radh 138958 (CALI!); Choondal, Mathikettan, 23.04.2016, Syam Radh \& Arunkumar 149114, 149115, 149116 , 149118, 149119 (CALI!); Sivan Para, on the way to Mathikettan, 26.06.2016, Syam Radh 149160 (CALI!).
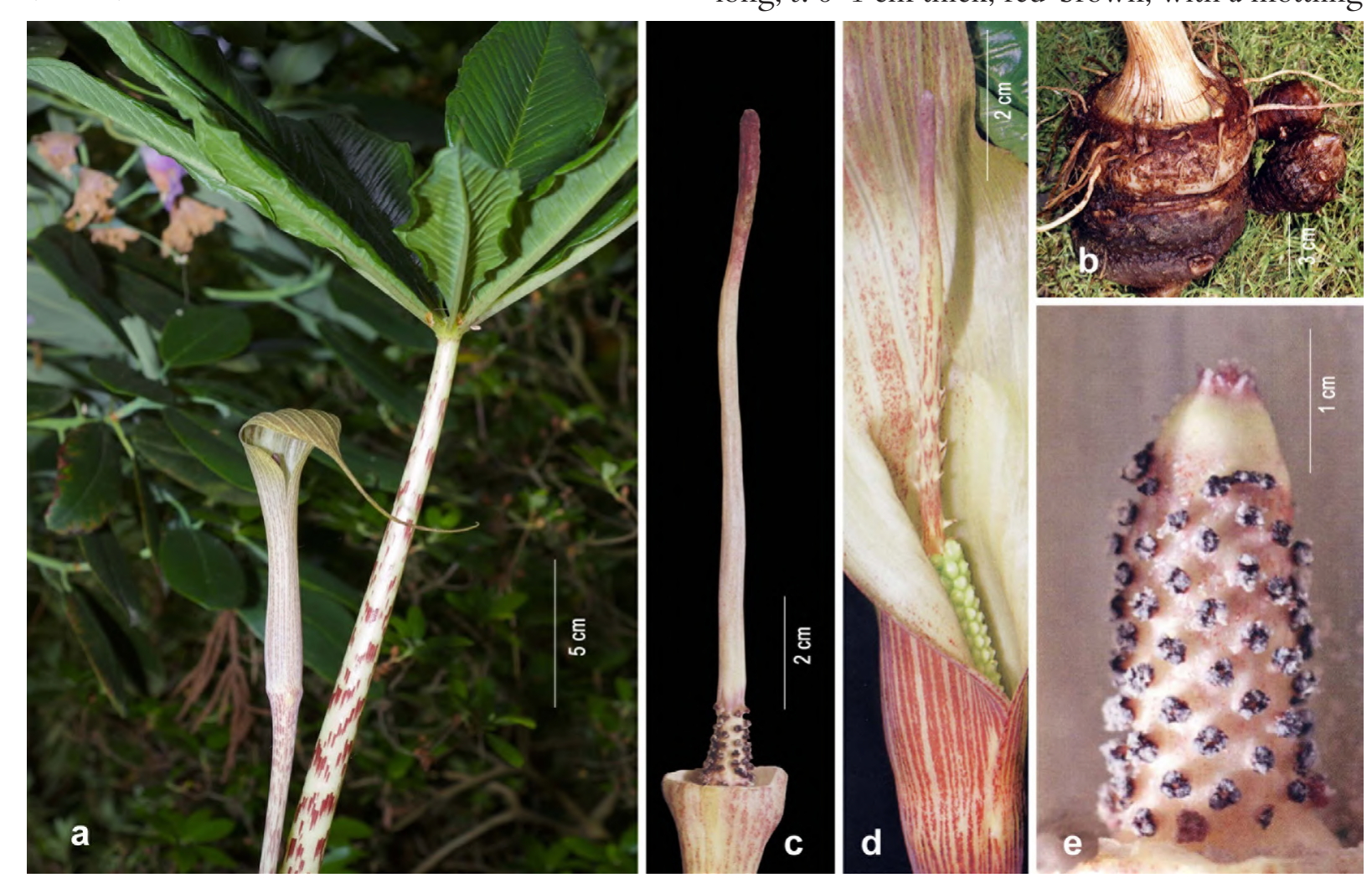

Figure 25. Arisaema siangense Gusman: a. Habit; b. Corm; c. Male spadix; d. Female spadix; e. Male floriferous region (Images, Guy Gusman, Belgium).
Arisaema siangense Gusman, Syst. Geogr. Pl. 76: 229. 2006. Type: INDIA, Arunachal Pradesh, Siang District, c. 1300 m, July 1997, Gusman GG97144 (holo BR849801 digital image!; iso CAL! \& BM!).

Fig. 25.

Deciduous, dioecious, perennial herb, to 1.85 $\mathrm{m}$ tall. Subterranean stem an annulate tuberous corm, subglobose or elongated, c. 6-12 cm diam., 5-14 cm tall, brown outside, offsets elongate and pyriform. Roots thick, pink to white. Cataphylls usually $3,5-50 \mathrm{~cm}$ long, similar in colour to the pseudostem. Leaf solitary, radiatisect, emerging with the inflorescence; petiole 50-60 cm long, $1.5-2 \mathrm{~cm}$ thick, smooth, olive-green with carmine stripes; leaflets to 11 , elliptic-obovate, $25-40 \mathrm{~cm}$ long, 7-9 cm wide, base cuneate or decurrent, subsessile or with a green petiolule, up to $10 \mathrm{~mm}$ long, apex long acuminate, margins undulate, green, entire or serrate, shiny green with deeply impressed veins above, underside glaucous with strongly prominent veins. Pseudostem 30-60 cm long, 3-4 cm wide, olive-green or pale redbrown with transverse vermillion markings and/ or carmine stripes. Inflorescence held below the foliage; peduncle shorter than the petiole, $5-20 \mathrm{~cm}$ long, c. 6-1 cm thick, red-brown, with a mottling 
similar to the pseudostem. Spathe $18-33 \mathrm{~cm}$ long including tail; tube of spathe subcylindrical, 6-10 $\mathrm{cm}$ long, c. $1.5 \mathrm{~cm}$ wide above, narrowing in the upper third, c. $0.8 \mathrm{~cm}$ across, then flaring again at mouth, dark pink outside with faint paler stripes becoming olive-green near the spathe mouth, white-yellow inside with dotted purple stripes mainly in the lower half; mouth-margins straight to slightly recurved and olive-green; limb horizontal, ovate-lanceolate, $4-8 \mathrm{~cm}$ long (not counting the tip); $3-5 \mathrm{~cm}$ wide, shorter than the tube, outside and inside dull orange-yellow with pale pink stripes; acuminate at apex, prolonged into a tail, 8-15 cm long, olive-green turning pink at the end. Female spadix 6-10 cm long; pistils densely arranged; pistils many, bottle-shaped, sessile yellow-green; style short or absent; stigma white and penicillate; appendix subcylindrical, usually hardly exserted from the spathe tube, erect, 4-7 $\mathrm{cm}$ long, exceptionally extremely short, ending in a clavate, knobbly and light carmine apex, middle part white-yellow with pink stripes, smooth, $0.2-0.4 \mathrm{~cm}$ wide, lower part white-yellow, pink striped; neuters stiff, short and upcurved, 1-3 mm long, white-yellow, few in number; male fertile zone slightly conical, $1.5-3 \mathrm{~cm}$ long and $7-10 \mathrm{~mm}$ wide; male flowers loosely arranged, 2-4-androus; anthers pink, subsessile, dehisce through an elongated pore; pollens cream; neuters absent. Fruiting spike conical, 7-14 cm long and 3-6 cm wide, borne on an upright peduncle; receptacle cream-coloured; berries rounded, upper part flat, densely packed, bright red 1-3-seeded.

Flowering \& fruiting: May-December.

Habitat: Grows at the base of deciduous trees, among bamboos and ferns, in clay, near streamlets and in bogs, at $c .1300 \mathrm{~m}$ elevation. A. siangense thrives along roads, often near riverbanks and among shrubs. Some specimens were over 1.80 $\mathrm{m}$ tall and this species might be the tallest in Sect. Sinarisaema.

Distribution: India (North-East Himalayas), endemic.

Specimens examined: INDIA, Arunachal Pradesh, Upper Siang district, Yingkyong, $3 \mathrm{~km}$ east on Hills, 12.03.2004, Ritesh Kumar Choudhary 16242 (ARUN!). Upper Dibang Valley district, Amboli, 08.05.1999, M. Bhaumik 2310 (CAL!); Punli,
30.04.1998, M. Bhaumik 1502 (CAL!).

Notes: This species is close to $A$. concinnum and one can easily misidentify this species when dried. However, it can be distinguished by its huge annulate corms, spathe tubes narrowed at middle, orange coloured spathe limbs and spadix appendix not knobbed as in the former.

Arisaema subulatum Manudev \& Nampy, sp. nov. Closely similar to A. leschenaultii Blume, from which it is distinguished by petiolulate leaflets and sessile, cylindric spadix appendix, rugulose at apex, with subulate, upcurved neuters, scattered along the base.

Type: INDIA, Kerala, Thiruvananthapuram District, Athirumala, on slopes, Agasthyamala, 06.06.2014, Manudev \& Arunkumar 138939 (holo CALI!; iso MH).

Fig. 26

Deciduous, dioecious, perennial, succulent herbs, c. $1.3 \mathrm{~m}$ tall. Subterranean stem a tuberous corm, globose-depressed globose, 4.5-8 cm diam., 3-5.5 $\mathrm{cm}$ tall, greenish inside. Cataphylls 3 , rarely 4 , pale or purplish to flesh coloured or rose, greenish towards apex, rose-pinkish mottled, obtuse at apex, mucronulate; outer 3-8 cm long, flesh coloured or rose; middle $6-16 \mathrm{~cm}$ long, pale coloured with rose mottling, slightly greenish towards distal end; inner 20-46 cm long, green in colour with rose or pinkish mottling, wrapping the pseudostem; sometimes an outer fourth cataphyll $2-2.5 \mathrm{~cm}$ present. Leaf single, radiatisect, unfolding with the inflorescence; petiole $c .130 \mathrm{~cm}$ long, 1.3-3.5 cm thick, green with purplish or rose coloured spots; leaflets 6-10, petiolulate, obovate-spathulate; 26$40 \mathrm{~cm}$ long, 7-11 cm wide, cuneate at base, acute to acuminate at apex, margins slightly undulate, dark green above, pale beneath. Pseudostem c. 75 cm long, 2-3.5 cm thick, mottled as in petiole. Inflorescence emerges with and held below the leaf; peduncle $c .90 \mathrm{~cm}$ long, 1.5-2 cm thick, green, faintly mottled with purple, exserted by c. $14 \mathrm{~cm}$ long from the sheathing pseudostem. Spathe 16-30 $\mathrm{cm}$ long; tube of spathe cylindric, slightly funnelshaped towards the mouth, $6-11 \mathrm{~cm}$ long, $2-2.5 \mathrm{~cm}$ wide, purple-greenish outside, dark purple inside, white striped along the veins; mouth margins auriculate, recurved; spathe limb ovate-lanceolate, 9-11 cm long, 5-6 cm wide, gradually tapering in to tail 3-9 $\mathrm{cm}$ long at the apex, margins slightly 


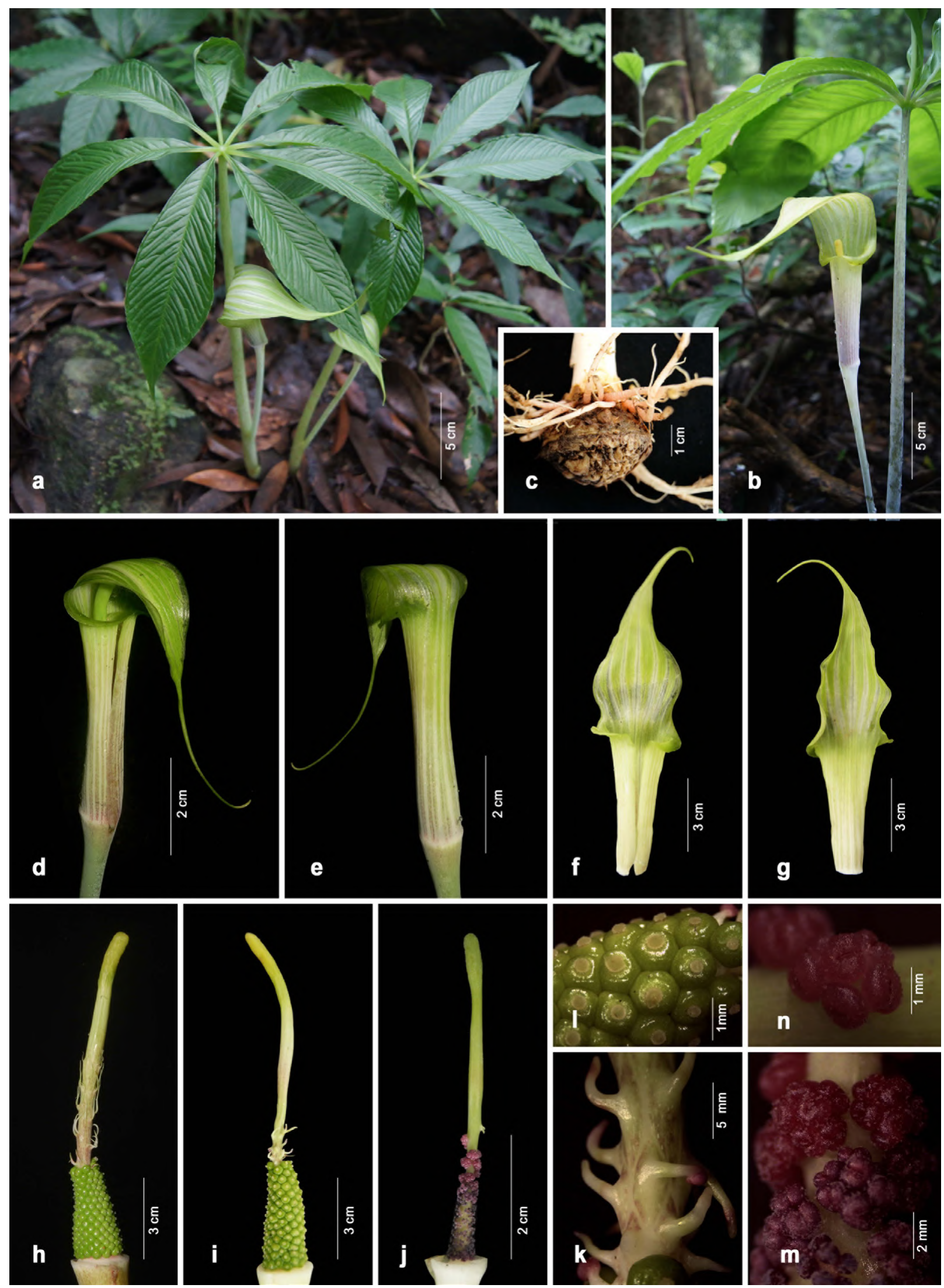

Figure 26. Arisaema subulatum Manudev \& Nampy: a \& b. Habit; c. Corm; d \& e. Inflorescences; $\mathbf{f}$. Spathe-front view; g. Spathe-back view; h \& i. Female spadix; j. Male spadix; k. Neuters with aborted anthers; I. Female floriferous region; $\mathbf{m} \& \mathbf{n}$. Male flowers-enlarged view. 
revolute, yellowish-green, hyaline to white striped, erect and arching forward to a horizontal position, drooping downwards after anthesis. Female spadix 10-13 cm long, cylindric, sessile; female floriferous region conical 3-4 cm long; pistils compactly arranged, globose, green; style absent; stigma papilose, white; ovules 5; neuters subulate, 0.6$1.2 \mathrm{~cm}$ long, upcurved, scattered, $2-5 \mathrm{~cm}$ along the base of appendix, pale to green or purplish; appendix sessile, cylindric or terete, c. $9 \mathrm{~cm}$ long, $0.6-0.7 \mathrm{~cm}$ thick, green, purplish towards base, yellow-green at apex, slightly curved, rugulose and blunt at apex, exserted $c .1 .5 \mathrm{~cm}$ from the tube. Male spadix similar to female, slender, $5.5-6 \mathrm{~cm}$ long; floriferous region cylindric, $2-2.5 \mathrm{~cm}$ long, $c$. $0.5 \mathrm{~cm}$ wide; male flowers sessile, densely arranged below and scattered above, 4-7-androus; anthers reniform, purple, sessile, dehisce through an apical oblong pore; neuters usually absent, rarely very few, subulate. Fruiting spike not seen.

Flowering \& fruiting: May-October.

Habitat: In evergreen forests and shola margins, in humus rich soil and rock crevices.

Etymology: This taxon is named after the subulate neuters scattered along c. $5 \mathrm{~cm}$ at the base of spadix appendix.

Distribution: India (southern Western Ghats), endemic.

Specimen examined: INDIA, Kerala, Thrissur Dist., Sholayar to Malakkapara road, 09.07.2012, Manudev 5085 (CALI!).

Notes: This species is very close to $A$. leschenaultii Blume, and is likely to get confused as a variant of the latter. However, it can be distinguished by its sessile spadix appendix which is rugulose at apex (vs. stipitate spadix appendix with smooth apex) with subulate upcurved neuters, scattered along the base ( $v s$. neuters restricted below the stipe). It is also close to $A$. peerumedense from which it can be distinguished by the presence of petiolulate leaflets (vs. sessile leaflets), yellowish greenish spathe limb (vs. pale to dark purple limb) and a cylindric or terete spadix appendix with rugulose apex ( $v s$. cylindric-fusiform appendix with smooth apex).

Arisaema translucens C.E.C.Fisch., Bull. Misc. Inf., Kew 1933 (7): 344. 1933; in Gamble, Fl. Pres. Madras 3(11): 1891. 1936; Chatterjee, Bull. Bot.
Soc. Bengal 8: 136. 1955; Gusman \& L.Gusman, Gen. Arisaema ed. 2. 409. 2006; Prabhukumar et al., Phytotaxa 306: 85. 2017. Type: INDIA, Tamil Nadu, Nilgiris district, Carrington Tea Estate, near Thia shola, 1820 m, E. Barnes AR.4 (K000499314 digital image!; iso $\mathrm{MH}$ !)

Deciduous, dioecious, perennial herbs, $c .35 \mathrm{~cm}$ tall. Subterranean stem a tuberous corm, subglobose, 1-5 cm. diam., white. Roots many from the upper side of the corm. Cataphylls 3, c. $9 \mathrm{~cm}$ long, rounded at apex, pinkish-purple, outermost becoming chaffy. Leaf solitary, radiatisect; petiole $c$. $35 \mathrm{~cm}$. long, pinkish-purple with brown and pink markings or pink with brown and white markings; leaflets 9-11, sessile, narrowly elliptic-oblanceolate, 9-14 cm long, 1.7-3 cm wide, cuneate at base, finely acuminate, margins revolute, erose, dull velvety green above, slightly glossy below, midrib and numerous primary lateral nerves prominent below. Inflorescence held below the leaf; peduncle c. $20 \mathrm{~cm}$ long, slender, resembling the upper part of the petiole. Spathe $c .7 \mathrm{~cm}$ long; tube of spathe cylindric, slightly widened to the mouth, 3.5-4.3 $\mathrm{cm}$ long, 1-1.3 cm wide, green and purple with a few white stripes; limb cucullate, c. $2.5 \mathrm{~cm}$. long, leaving a narrowly obcordate, opening from the apex of which depends a filiform tail $2.5-3 \mathrm{~cm}$ long with an upcurved tip, purple with broad translucent bands. Female spadix nearly cylindric, 4-5.4 cm long; floriferous region narrow, 1-1.5 cm long; pistils crowded, subglobose, 1.5-2 mm diam.; style very short; stigma minutely papillose; ovules 4; neuters a few, scattered, subulate, c. 5 $\mathrm{mm}$ long, rarely with an aborted anther at the tip; appendix narrowly clavate, slightly narrowed and rounded at the apex, green with faint purple stripes, the apical quarter white. Male spadix similar to female, slender; floriferous region narrow, c. 2 cm long; male flowers scattered, shortly stipitate, 2-6-androus; anthers purple, dehisce by an elliptic pore; neuters absent. Fruiting spike not seen.

Flowering: June.

Habitat: In grasslands, under pine woods at an elevation above $1300 \mathrm{~m}$ above sea level.

Distribution: India (southern Western Ghats), endemic.

Specimens examined: INDIA, Tamil Nadu. Nilgiris district, Pykara, under shade, 05.1889, J.S. Gamble 
20514 (CAL!); Thaishola, beyond Carrington estate, towards Kakamalai, 10.06.1933, E. Barnes 333 (MH!); ibid., Kakkamalai, 10.06.1933, E. Barnes $336(\mathrm{MH} !)$.

Notes: Fischer (1933) described this narrow endemic species from the collections of Barnes from Nilgiris, Tamil Nadu. Closest ally of this taxon is $A$. agasthyanum, another narrow endemic species from southern Western Ghats. Both species are smaller in size and a purple, cucullate or almost galeate spathe limb with translucent-whitish bands are peculiar in this species. Recently Prabhu Kumar et al. (2017) rediscovered this taxon from its type locality.

Arisaema tuberculatum C.E.C.Fisch., Bull. Misc. Inform., Kew 1935(1): 66. 1935; in Gamble, Fl. Madras 3(11): 1890. 1935; Chatterjee, Bull. Bot. Soc. Bengal 8: 137. 1955; Sivad. in Manoharan et al., Silent Valley-Whispers of Reason 236. 1999; V.S.Ramach. \& Paulraj, J. Bomabay Nat. Hist. Soc. 105(2): 228. 2008; Gusman \& L.Gusman, Gen. Arisaema, ed. 2. 398. 2006; Prabhukumar et al., Phytotaxa 306: 89. 2017. Arisaema convolutum C.E.C.Fisch., Bull. Misc. Inform., Kew 1934(4): 167. 1934, non Nakai 1929. Type: INDIA, Tamil Nadu, Nilgiris district, Pennant Shola, Parson's Valley, 2133-2286 m (7000-7500 ft), May-June, E. Barnes AR7(a-h) (K digital images!).

Fig. 27

Deciduous, dioecious, succulent, perennial herbs, up to $95 \mathrm{~cm}$ tall. Subterranean stem a tuberous corm, depressed globose to subglobose, 2-5.4 cm diam., 1-3.5 cm tall, cream-white or brownish, offsets often present in mature corms, a few, surrounding the pseudostem. Roots many, pale brown to rose, from the upper side of the corm. Cataphylls 3 or 4 , acute or obtuse at apex, mucronate; outer $c$. 2.5-7.5 cm long, pale to white often blushed with rose; middle $5.5-15 \mathrm{~cm}$ long, pale brown to pale rose, faintly mottled; inner 16-30 cm long, enclosing the pseudostem, pale rose, pale to dark brown, faintly mottled, sometimes cylindric below; often an outer pale-hyaline cataphyll c. 1-3 cm long also seen. Leaf solitary, radiatisect, usually unfolds completely before the emergence of inflorescence or together; petiole $38-95 \mathrm{~cm}$ long, $0.5-1.5 \mathrm{~cm}$ thick, pale green to greenish white above, rose to brown tinged below, not mottled; leaflets 5-8, sessile, ellipticoblanceolate, $15.5-28.5 \mathrm{~cm}$ long, 3-6.8 cm wide, long-acuminate, margins entire, often wavy or undulate, dark green above, pale below. Pseudostem 13.5-29 cm long, 1.5-2.5 cm thick, wrapped by cataphylls, pale to dark green. Inflorescence matures before the emergence of leaf in male plants often over and decomposing by the time leaf has fully expanded; peduncle 29-63 cm long, light green, pale green, not mottled, exserted by $13-15.5 \mathrm{~cm}$ long from the pseudostem. Spathe $16-24.5 \mathrm{~cm}$ long; tube of spathe cylindric, funnel-shaped towards the mouth, 6-8.5 cm long, $1.5-2 \mathrm{~cm}$ wide, pale-green to green, or pale-purple with white-pale stripes along the veins; margins of the mouth slightly dilated to a revolute auricular extension; limb ovate-lanceolate,
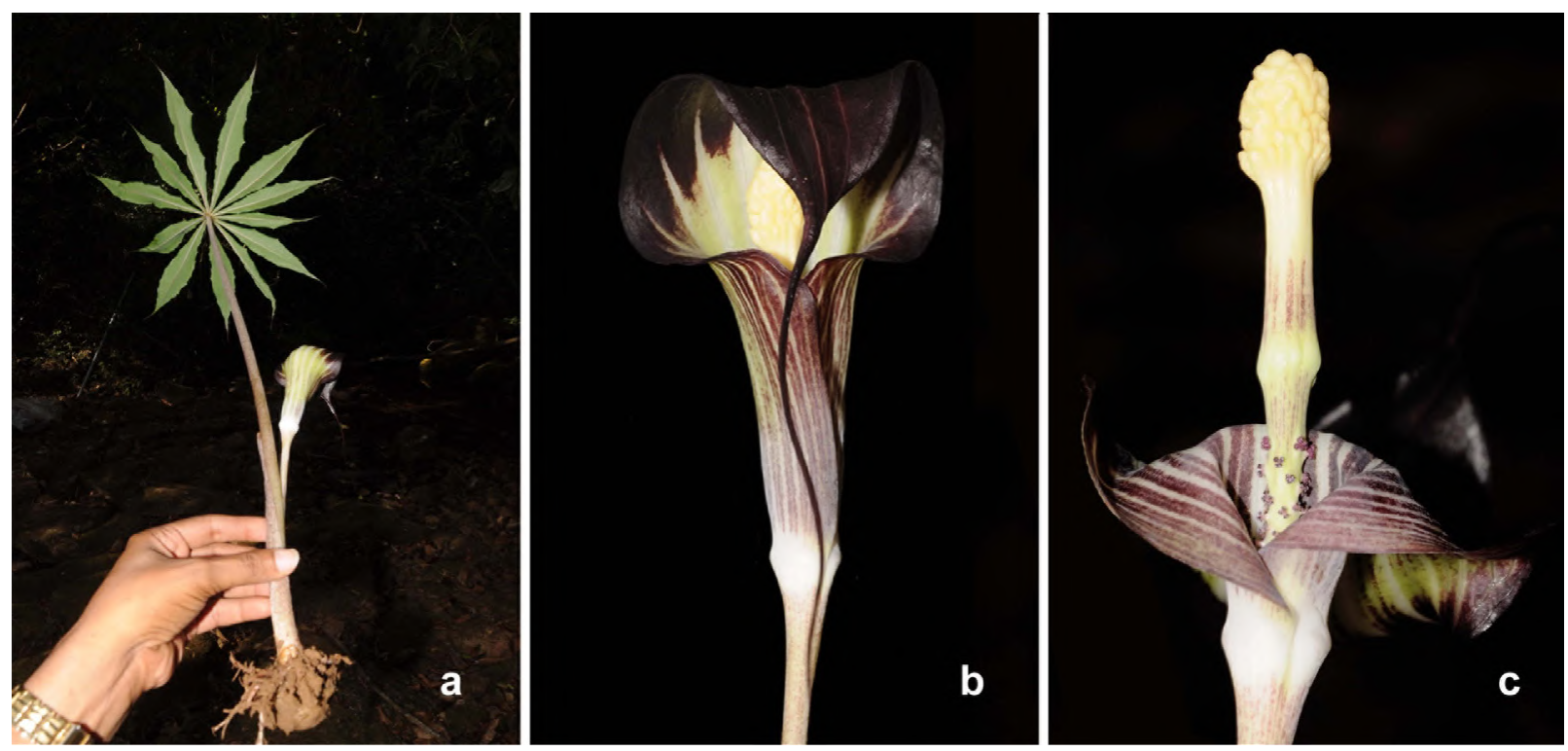

Figure 27. Arisaema tuberculatum C.E.C.Fisch.: a. Habit; b. Inflorescence-side view; c. Inflorescence-front view; d. Male spadix (Images A.J. Robi). 
10-16 cm long, 3.3-5.2 cm wide, acuminate with a long tail, 5-9 cm long, green, purple to dark brown all over with white to pale greenish white stripes along the veins, arched over and drooping. Female spadix sessile, c. $10 \mathrm{~cm}$ long, $0.3-0.4 \mathrm{~cm}$ thick; fertile region $2-4 \mathrm{~cm}$ long, followed by a few neuters; pistils many, sessile, globose, compactly arranged, sometimes angled owing to the compact arrangement, green; ovules 3-5, white; style short; stigma papillate, stellate, peltate; neuters subulate, a few, 0.5-1.5 cm long, scattered, upcurved, green; appendix decidedly stipitate with a slight thickening at the base after neuters, unevenly angled, reaching the mouth of the tube or just exceeding, slender and gradually tapering, green to light green, apex blunt-truncate, subcapitate-capitate and purplishdark brown. Male spadix sessile, similar to female, c. $4.5 \mathrm{~cm}$ long, $0.3-0.4 \mathrm{~cm}$ thick; fertile region narrow, c. $1.6 \mathrm{~cm}$ long; male flowers scattered over or crowded at the base and distant above, sessile or shortly stipitate, 2-4-androus; anthers sessile, purple, dehisce by an apical pore; neuters usually absent or very few, as small protruberance. Fruiting spike not seen.

Flowering: May-June.

Habitat: In evergreen forests, growing in leaf mould, also on horizontal branches, in forks and on the roots of trees.

Distribution: India (southern Western Ghats), endemic.

Specimens examined: INDIA, Tamil Nadu, Nilgiris district, Pennant Shola, Parson's Valley, 20.05.1933, E. Barnes 677 (MH!). Kerala, Palakkad district, Sispara, Silent Valley National park, c. 2250 m, 09.03.2016, Robi Jose 22335 (KFRI).

Notes: This species is closely allied to A. leschenaultii but can be distinguished by long-caudate spathe limb and spadix appendix with a convolute apex.

Conservation status: Arisaema tuberculatum is endemic to Tamil Nadu. The species is very rare and collected from the wild only once after its description (Ramachandran \& Paulraj, 2008). This species has been spotted recently from Sispara in Silent Valley (Palakkad district of Kerala) with an unusual flowering period. However these two collections are from localities within 100 $\mathrm{km}$ diameter from the type locality. Based on the
'Extent of Occurrence' (EOO $<100 \mathrm{~km}^{2}$; Criterion B1) and 'Area of Occupancy' [Criterion B2: AOO $<10 \mathrm{~km}^{2}$ with number of location $=1$ (subcriterion ' $a$ '), projected decline in area and extent and/or quality of habitat [sub-criterion ' $b$ (iii)'], $A$. tuberculatum may be considered as 'CRITICALLY ENDANGERED’ [CR: B1, B2a, b(iii)] according to IUCN's guidelines (IUCN SPS, 2017).

Arisaema tylophorum C.E.C.Fisch., Bull. Misc. Inform., Kew 1933(7): 346. 1933; in Gamble, Fl. Pres. Madras 3(11): 1891. 1936; Chatterjee, Bull. Bot. Soc. Bengal 8: 137. 1955; Sivad. in Manoharan et al., Silent Valley-Whispers of reason 241. 1999.

Type: INDIA, Tamil Nadu, Nilgiris district, Thaishola, 1828 m, 16.06.1932, E. Barnes AR6c (K000950304 digital image!).

A. barnesii auct. Gusman \& L. Gusman, Arisaema ed. 2. 357. 2006, pro parte, non Fischer 193.

Fig. 28.

Deciduous, dioecious, perennial herbs, $c .30 \mathrm{~cm}$ tall. Subterranean stem a tuberous corm, globose, 1-2 $\mathrm{cm}$ diam.. Roots many, from the upper side of the corms, red. Cataphylls 3, apex rounded, innermost up to $13 \mathrm{~cm}$ long, mottled with brown, becoming chaffy. Leaf solitary, radiatisect; petiole $19-26 \mathrm{~cm}$ sheathing below the middle, light-green marbled with brown and pink; leaflets 5-7, petiolulate, elliptic-lanceolate to elliptic-oblanceolate, 5.3$26 \mathrm{~cm}$ long, 1.6-9 cm wide, cuneate at base, acuminate or caudate-acuminate at apex, margin erose, dark-green above with a waxy lustre, bright green and very glossy below; petiolules $1-1.8 \mathrm{~cm}$ long. Inflorecence held below the leaf; peduncle slender, c. $18 \mathrm{~cm}$ long, coloured as the petiole. Spathe 5-7 cm long; tube of spathe cylindric or very narrowly funnel-shaped, $2.5-4.5 \mathrm{~cm}$ long, $1-1.2 \mathrm{~cm}$ wide at the mouth, white with vertical purple stripes within; limb ovate, slightly galeate, abruptly caudate, $1.5-2.5 \mathrm{~cm}$ long, bright-green, overarching, the filamentous tail $0.8-2 \mathrm{~cm}$ long, upcurved at the apex and terminated by a distinct small spherical or clavate knob. Female spadix 4.5-6.5 cm long; floriferous region $0.8-2 \mathrm{~cm}$ long; pistils ovoid, compactly arranged, sometimes lax with a few anthers between, green; ovules 4-6; style short; stigma minutely papillose; neuters a few, subulate, c. $0.5 \mathrm{~cm}$ long, rarely forked, green or white; appendix nearly cylindrical or slightly 
angled, slender, narrowed and curved near the apex, terminating in a distinct, minutely-warted knob. Male spadix similar to female, $4-5.5 \mathrm{~cm}$ long; floriferous region narrow conical, $1.2-1.7 \mathrm{~cm}$ long; male flowers laxly arranged, sessile, 2-4-androus; anthers purple, sessile, dehisce through an oblong pore, sometimes with few pistils below; neuters usually absent, sometimes few above the male flowers, subulate. Fruiting spike not seen.

Flowering: May-June.

Habitat: In wet shola forests and in cinchona plantations at an elevation above $1800 \mathrm{~m}$.

Distribution: India (southern Western Ghats), endemic.
Specimens examined: INDIA, Tamil Nadu, Nilgiris district, Thiashola, near Carrington estate, c. 2185 m, 03.06.2019, Manudev \& Arunkumar 144888, 144892 (CALI!); Avalanche, way side, c. 2100 m, 04.06.2019, Manudev \& Arunkumar 144893, 144894 (CALI!).

Notes: This species is one of the smallest species occurring in southern Western Ghats. Gusman and Gusman (2006) treated it as conspecific to $A$. barnesii C.E.C.Fisch. but it can be easily identified by its slightly galeate spathe limb with abruptly caudate apex terminating to a small knob. This species also similar to $A$. attenuatum C.E.C.Fisch., in its shorter spathe limb with a whitish spot at the base and a slender spadix appendix but can be
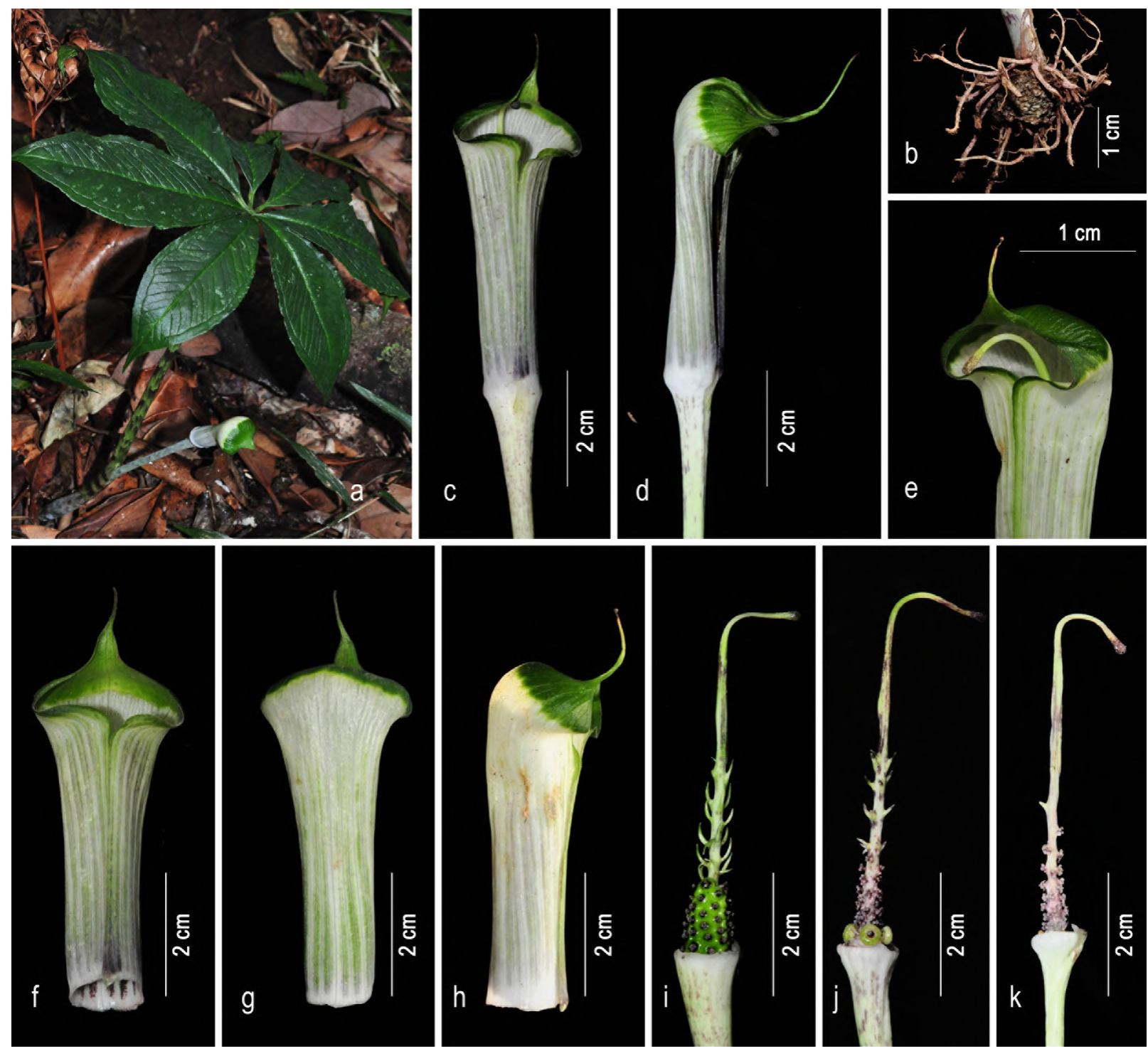

Figure 28. Arisaema tylophorum C.E.C.Fisch.: a. Habit; b. Corm; c \& d. Inflorescences; e. Mouth with knobbed spadix appendix; f. Spathe-front view; g. Spathe-back view; h. Spathe-side view; i. Female spadix; j. Male spadix with pistils at base and neuters above; k. male spadix. 
distinguished by the presence of a distinct knob at the tip of the caudate spathe limb and spadix appendix.

Conservation status: Arisaema tylophorum is very rare and collected from the wild only once after its description (Sivadasan, 1999). Based on 'Extent of Occurrence' (EOO<100 km²; Criterion B1) and 'Area of Occupancy' [Criterion B2: AOO $<10$ $\mathrm{km}^{2}$ with number of location $=1$ (sub-criterion 'a'), projected decline in area and extent and/ or quality of habitat [sub-criterion 'b (iii)'], $A$. tylophorum may be considered as 'CRITICALLY ENDANGERED' [CR: B1, B2a, b(iii)] according to IUCN's guidelines (IUCN SPS, 2017).

\section{Acknowledgements}

Authors are thankful to the Directors/in-charges and Curators of ASSAM, BLAT, BSD, BSI, CAL, CALI, DD, DEV, JCB, MH, RHT, \& TBGT for permission to consult the herbarium; forest departments of Arunachal Pradesh, Karnataka, Kerala, Maharashtra, Meghalaya, Sikkim, and Tamil Nadu for permissions; Pascal Bruggeman (Netherlands) for providing the literature input, photographs and discussions on various Arisaemas in his personal collection; Dr. K.N. Gandhi (Registrar, Harvard University) for discussions on nomenclature; Guy Gusman (Universite Libre de Bruxelles) and Dr. A.P. Das (Rajiv Gandhi University, Arunachal Pradesh), Dr. Robi Jose, BAM College, Pathanamthitta for photographs. Authors are also thankful to SERB for financial assistance.

\section{Literature cited}

BLATTER E. 1931. A. murrayi and A. longecaudatum. Journal and Proceedings of the Asiatic Society of Bengal 26: 362-365.

ENGLER A. 1879. Araceae. In: CANDOLlE A. \& C. CANDOLLE (eds.), Monographice phanerogamarum, Volume 2. G. Masson, Paris. pp. 1-681.

ENGLER A. 1920. Araceae-Pistioideae. In: ENGLER A. (ed.), Das Pflanzenreich Regni vegetabilis conspectus, Volume IV. 23F. Verlag von Wilhelm Engelmann, Leipzig.

FISCHER C.E.C. 1933. New or little known plants from South India: II. Bulletin of Miscellaneous Information, Royal Gardens, Kew 1933: 339-357.

FISCHER C.E.C. 1936. New or little known plants from South India: VII. Bulletin of Miscellaneous Information,
Royal Botanic Gardens, Kew 1936: 274-278.

GOUDA E.J. \& G. GUSMAN 1999. A new variety of Arisaema ciliatum (Araceae). Blumea 44: 37-39.

GOVAERTS J., BOGNER J., BOOS J., BOYCE P., COSGRIFF B., CROAT T., GONSALVES E., GRAYUM M., HAY A., HETTERSCHEID W., ITTENBACH S., LANDOLT E., MAYO S., MURATA J., NGUYEN V.D., SAKURAGUI C.M., SINGH Y., THOMPSON S. \& G. ZHU 2019. World Checklist of Araceae. Facilitated by the Royal Botanic Gardens, Kew. Published on the internet: http://apps. kew.org/wcsp/(Accessed 20.06.2019).

GUSMAN G. \& L. GUSMAN 2002. The Genus Arisaema - A monograph for botanists and nature lovers. A. R. GantnerVerlag, Ruggell.

GUSMAN G. \& L. GUSMAN 2006. The genus Arisaema A monograph for botanists and nature lovers, Second revised and enlarged edition. A.R.G. Gantner Verlag, Ruggell.

HARA H. 1971. A revision of the eastern Himalayan species of the genus Arisaema (Araceae): Flora of Eastern Himalaya. Second Report. University of Tokyo Press, Tokyo, pp. 322-354.

HOOKER J.D. 1893. Arisaema. In: HOOKER J.D. (ed.), Flora of British India, Volume 6. L. Reeve \& Co., London. pp. 407-508.

LI H., ZHU G. \& J. MURATA 2010. Arisaema. In: WU Z.Y., RAVEN P.H. \& D.Y. HONG (eds.), Flora of China, Volume 23. Missouri Botanical Garden Press, St. Louis. pp. 43-69.

IUCN STANDARDS AND PETITIONS SUBCOMMITTEE 2017. Guidelines for using the IUCN Red list categories and criteria, Version 13. Accessed on 28.03.2019.

MANUDEV K.M. \& S. NAMPY 2015. Arisaema peltatum (Araceae): an endemic cobra lily recollected after type collection from southern Western Ghats, with notes on its taxonomic status. ENVIS News Letter 20(1): 4.

MANUDEV K.M. \& S. NAMPY 2016. Lectotypification of Arisaema consanguineum Schott (Araceae). Candollea 61: 58-60.

MANUDEV K.M. \& S. NAMPY 2017. Second-step lectotypification of three names of Araceae from India. Phytotaxa 302(1): 90-94. https://doi.org/10.11646/ phytotaxa.302.1.9

MANUDEV K.M., NAMPY S. \& P.G. ARUNKUMAR 2015. Arisaema ciliatum H. Li var. liubaense Gusman \& Gouda (Araceae), a new record for India. Pleione 9: 226-230. 
MURATA J. 1984. An attempt at an infrageneric classification of genus Arisaema (Aracaeae). Journal of the Faculty of Science, University of Tokyo, Section III. Botany 13: 431-482.

MURATA J. 2011. Arisaema in Japan- The picture book of plant systematics in color. Hokuryukan Publishing Co. Ltd., Tokyo.

MURATA J., NAGAMASU H. \& H. OHASHI 2013. A nomenclatural review on the infrageneric classifications of Arisaema (Araceae). Journal of Japanese Botany 88: 36-45.

NAKAI T. 1950. Classes, ordines, familiae, subfamiliae, tribus, genera nova quae attinent ad plantas Koreanas (supplimentum). Journal of Japanese Botany 25: 5-7.

NICOLSON D.H. 1988. Araceae. In: DASSANAYAKE M.D. \& F.R. FOSBERG (eds.), A revised handbook to the flora of Ceylon, Volume 6. Oxford \& IBH Publishing Co. Pvt. Ltd., New Delhi. pp. 17-101.

PRABHUKUMAR K.M., CHHABRA T., ROBI A.J., JAGADEESAN R., SUNIL C.N. \& I. BALACHANDRAN 2017. Rediscovery of Arisaema translucens (Araceae) and notes on $A$. tuberculatum, two strict endemics of Nilgiris, India. Phytotaxa 306: 085090. https://doi.org/10.11646/phytotaxa.306.1.7

RAMACHANDRAN V.S. \& S. PAULRAJ 2008. Arisaema tuberculatum C.E.C.Fisch. (Araceae) from Mukurthi National Park, Nilgiri Biosphere Reserve, Tamil Nadu, India. Journal of Bombay Natural History Society 105: 228-229.
RAO R.S. \& K.K. AHUJA 1969. Arisaema caudatum Engl. - its identity, typification and affinities. Bulletin of Botanical Survey of India 11: 450-452.

SCHOTT H.W. 1856. Synopsis Aroidearum. Congregationis Mechitharisticae, Vienna. pp. 25-33.

SCHOTT H.W. 1859. Aroideen-Skizzen. Bonplandia 7: 26-31.

SCHOTT H.W. 1860. Prodromus Systematis Aroidearum. Mechitarists's Press, Vienna. pp. 24-60.

SIVADASAN M. 1999. Araceae of Silent Valley and neighbourhood. In: MANOHARAN T.M., BIJU S.D., NAYAR T.S. \& P.S. EASA (eds.), Silent ValleyWhispers of reason. Kerala Forest Department, Thiruvananthapuram pp. 236-237.

SIVADASAN M. \& D.H. NICOLSON 1983. Arisaema nilamburense, a new name for a threatened species of India (Araceae). Aroideana 6: 36-38.

TURLAND N.J., WIERSEMA J.H., BARRIE F.R., GREUTER W., HAWKSWORTH D.L., HERENDEEN P.S., KNAPP S., KUSBER W.H., LI D.Z., MARHOLD K., MAY T.W., MCNEILL J., MONRO A.M., PRADO J., PRICE M.J. \& G.F.SMITH (eds.) 2018: International Code of Nomenclature for algae, fungi, and plants (Shenzhen Code) adopted by the Nineteenth International Botanical Congress Shenzhen, China, July 2017. Regnum Vegetabile 159. Glashütten: Koeltz Botanical Books. https://doi. org/10.12705/Code.2018 